Universidade de São Paulo

Instituto de Psicologia

Departamento de Psicologia Clínica

Tese de Livre Docência

Perspectivas fenomenológicas em atendimentos clínicos: humanologia

Andrés Eduardo Aguirre Antúnez

2012 
La humanidad es un gran todo: procede de una misma raíz, se dirige a un mismo fin, está implicada en un mismo destino (Edith Stein, 2007, p.19)

Car l'homme est fait pour rechercher I'human

(Eugène Minkowski, 1966/1999, p.25)

O homem começa onde começa esse viver definido como sentir-se a si mesmo, como provar-se, e acaba onde ele termina.

(Michel Henry, 2010, p.10)

No soy de aqui

Ni de allá

Soy de La humanidad. 
AUTORIZO A REPRODUÇÃO E DIVULGAÇÃO TOTAL OU PARCIAL DESTE TRABALHO, POR QUALQUER MEIO CONVENCIONAL OU ELETRÔNICO, PARA FINS DE ESTUDO E PESQUISA, DESDE QUE CITADA A FONTE.

Catalogação na publicação

Biblioteca Dante Moreira Leite

Instituto de Psicologia da Universidade de São Paulo

Antúnez, Andrés Eduardo Aguirre.

Perspectivas fenomenológicas em atendimentos clínicos: humanologia / Andrés Eduardo Aguirre Antúnez. -- São Paulo, 2012. $139 \mathrm{f}$.

Tese (Livre-Docência - Departamento de Psicologia Clínica.) Instituto de Psicologia da Universidade de São Paulo.

1. Afetividade 2. Fenomenologia 3. Intersubjetividade 4. Psicologia clínica I. Título. 


\section{Perspectivas fenomenológicas em atendimentos clínicos: humanologia}

Resumo: A partir de estudos de caso busca-se compreender a relação intersubjetiva na psicologia clínica por meio de três escolas da fenomenologia: a psicopatologia fenômeno-estrutural de Eugene Minkowski, a fenomenologia de Edith Stein, e a fenomenologia da vida de Michel Henry. As três modalidades clínicas apresentadas: atendimento clínico em grupo em ateliê de pintura de livre-expressão, acompanhamento terapêutico e psicoterapia, são refletidas e reposicionadas por essas vertentes fenomenológicas. O objetivo deste estudo é mostrar as potencialidades do estudo do humano em psicologia clínica, o que denomino humanologia. Observamos que o ateliê de desenho revela, no momento da verbalização, os segredos não revelados pelas imagens, indo de encontro aos fundamentos da criação e de facetas essenciais que o paciente busca comunicar por esse meio plástico e verbal; no acompanhamento terapêutico há a possibilidade de uma relação humana em movimento, próximo à vida como ela é e se apresenta, de modo que o acompanhante terapêutico observa e se relaciona no real e não no imaginário, mas no campo da afetividade. Na psicoterapia captamos a essência do sentido de existência, a potencialidade comunitária que pode ser desenvolvida na relação terapêutica, de modo que não mais nos dirigimos ao psíquico, mas ao humano. Assim, observamos que tanto no trabalho em grupo, nas ruas e na psicoterapia tradicional a relação humana se revela em primeiro plano e está na base de sua própria evolução. 0 encontro entre psicologia clínica e a fenomenologia pode contribuir com rico embasamento metodológico interdisciplinar, entre uma ciência qualitativa e prática e uma ciência eidética e teórica, de modo que ambas se enriquecem mutuamente.

Palavras chave: afetividade, fenomenologia, intersubjetividade, psicologia clínica. 


\section{Phenomenological Perspectives in Clinical Attendance: Humanology}

Abstract: Using case studies, the aim is to understand the intersubjective relationship in clinical psychology through three phenomenological schools: Eugene Minkowski's phenomeno-structural psychopathology; the phenomenology of Edith Stein; and Michel Henry's phenomenology of life. The three clinical modalities presented heregroup therapy in a free-expression painting studio; therapeutic accompaniment; and psychotherapy-are reflected upon and repositioned in relation to these phenomenological lines. The goal of the study is to show the potentialities of what I call humanology, i.e., the study of the human being in clinical psychology. We observe that, in the drawing studio, secrets not revealed in the images themselves are disclosed during verbalization, which meets halfway the fundaments of creation and the essential facets which the patient hopes to communicate through this visual/verbal medium. In therapeutic accompaniment there is the possibility of a human relationship in movement that is closer to life as it is and as it presents itself, such that the therapeutic companion can observe and relate to the subject in the real emotional world, rather than in an imaginary one. In psychotherapy, we capture the essence of the meaning of existence, the communitarian potentiality that can be developed in the therapeutic relationship, such that we cease to address the psychic and turn to the human. As such, we observe that in work in groups, in the street and in traditional psychotherapeutic settings the human relationship reveals itself in the foreground and at the base of its own evolution. The encounter between clinical psychology and phenomenology can provide rich interdisciplinary methodological grounds for a mutually enriching relationship between a qualitative, practical science and an eidetic, theoretical one.

Key words: humanology, phenomenology, clinical psychology, affectivity, intersubjectivity. 
Perspectivas fenomenológicas em atendimentos clínicos: humanologia

\section{SUMÁRIO}

Capítulo 1: Introdução. .07

Capítulo 2: Metodologia. .08

Capítulo 3: Autores e métodos fenomenológicos. .10

3.1. Edith Stein (1891-1942) ........................................................................11

3.2. O método fenomenológico a partir de Edith Stein....................................14

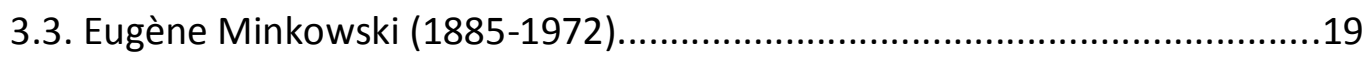

3.4. O método fenômeno-estrutural de Eugène Minkowski............................24

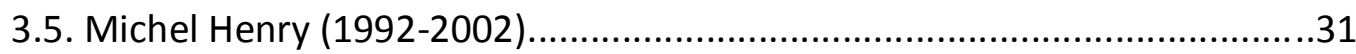

3.6. A fenomenologia da Vida (FdV) de Michel Henry....................................33

3.7. Da fenomenologia à clínica: em busca de uma humanologia....................39

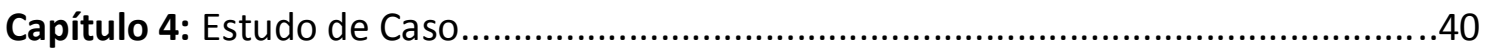

Capítulo 5: 0 atendimento clínico em grupo e os desenhos....................................42

5.1. Um exemplo de um encontro no Ateliê de Pintura de Livre Expressão.......51

5.2. Estudo de um caso com depressão: acompanhamento de quatro anos.....59

5.3. Os desenhos e as pinturas a partir de Michel Henry...............................79

Capítulo 6: Acompanhamento terapêutico (AT) e afetividade .82

6.1 Acompanhamento terapêutico à luz da fenomenologia da Vida de Michel Henry

Capítulo 7: Psicoterapia e Psicopatologia compreendida a partir dos estudos da empatia e da estrutura da pessoa humana e a psicologia em Edith Stein 103

7.1. A corporeidade em Stein.

7. 2. Uma compreensão fenomenológica das desordens psiquiátricas.

Capítulo 8: Considerações finais. 129 


\section{Capítulo 1: Introdução}

Este estudo em psicologia clínica se orienta pela prática vivida e experienciada pelo psicólogo clínico no atendimento clínico dual, em grupo e no acompanhamento terapêutico, embasado por uma perspectiva fenomenológica da clínica e da psicopatologia. O intuito é mostrar as amplas possibilidades relacionais da fenomenologia com a psicologia, a primeira como fundamento teórico e metodológico, a segunda, nos fundamentos da prática clínica dos atendimentos, em busca de mostrar o que denomino de humanologia na clínica.

O método utilizado é o fenomenológico associado à prática clínica. A opção pelo estudo de casos em psicopatologia foi fundamentada em Karl Jaspers e Eugène Minkowski. As fenomenologias usadas são da alemã Edith Stein e do francês Michel Henry, a psicopatologia fenômeno-estrutural de Eugène Minkowski e a clínica do idioma pessoal de Gilberto Safra. Os procedimentos utilizados partem da prática clínica e da investigação da experiência vivida na intersubjetividade.

Realiza-se uma investigação teórica sobre modalidades de atendimento clínico (atendimento clínico dual, em grupo, e no acompanhamento terapêutico) a partir de três escolas da fenomenologia europeia: a psicopatologia fenômeno-estrutural do psiquiatra russo polonês Eugène Minkowski (1885- 1972), a fenomenologia pura da filósofa alemã Edith Stein (1891-1943) e a fenomenologia da Vida do filósofo francês Michel Henry (1922-2002); do ponto de vista da psicologia clínica, algumas concepções de Gilberto Safra percorrerão todo o texto. Tanto Minkowski quanto Stein e Henry se guiaram a partir de Edmund Husserl, mas depois seguem seu próprio caminho; já Safra se orienta por um registro clínico-ontológico próprio. Eu os reúno para fundamentar o que denomino de humanologia ou estudo do humano na clínica.

A psicopatologia fenômeno-estrutural é um método que revela a expressão da linguagem e das ações dos pacientes; a fenomenologia de Edith Stein contribui com os estudos sobre a empatia (einfühlung) e a noção antropológica da estrutura da pessoa humana, que nos mostra a fecundidade dos estudos em relação à essência dos acontecimentos nos atendimentos clínicos, e a fenomenologia da vida ou 
fenomenologia não-intencional de Michel Henry se dirige à essência da vida, ou seja, à afetividade.

Nestas perspectivas não nos dirigimos apenas ao discurso verbal, mas à sensorialidade, à corporeidade e aos afetos na relação humana. O estudo busca mostrar como é possível investigar os fundamentos da clínica em contributos fenomenológicos, ampliando as noções da clínica e da psicopatologia.

As observações clínicas vividas mostram como é possível ter uma compreensão teórica advinda da ciência eidética ${ }^{1}$ de Edmund Husserl e ampliada por Edith Stein, questionada por Michel Henry e em diálogo próximo à psicopatologia fenômenoestrutural de Eugène Minkowski e a clínica hermenêutica de Gilberto Safra. Cada um desses autores contribui para refletir diversas facetas da clínica, apesar das distinções das perspectivas entre si e o rigor de cada método. É a humanologia que proponho e que reúne em mim essas vertentes.

\subsection{Objetivo}

Demonstrar como a experiência clínica me levou a desenvolver o que denomino humanologia, tendo encontrado em determinadas escolas da fenomenologia, da psicopatologia e da psicologia clínica contemporânea, contribuições que se aproximam com muita propriedade do que vivo na clínica, e que trazem novos aportes à psicopatologia e à psicoterapia tradicionais.

\section{Capítulo 2: Metodologia}

O método escolhido para nos acompanhar nessa investigação é o método fenomenológico (puro, fenômeno-estrutural, não-intencional e o clínico-ontológico). 0 objetivo é fundamentar fenomenologicamente três modalidades de atendimento

\footnotetext{
1 "A fenomenologia pura ou transcendental não será fundada como ciência de fatos, mas como ciência de essências (como ciência eidética); como uma ciência que pretende estabelecer exclusivamente "conhecimentos de essência" e de modo algum "fatos". A redução aqui em questão, que leva do fenômeno psicológico à "essência" pura ou, no pensamento judicante, da universalidade fática ("empírica") à universalidade de "essência", é a redução eidética". (Husserl, E, (2006). Idéias para uma fenomenologia pura e para uma filosofia fenomenológica. Aparecida: Idéias e Letras, p.28. (Originalmente publicado em alemão, 2002). Segundo Ales Bello (2006, p.22) “Husserl usa também a palavra grega eidos ( de onde vem a nossa palavra idéia, que neste caso não significa tanto um produto da mente, mas sentido), aquilo que se capta, que se intui".
} 
clínico: dual, em grupo e no acompanhamento terapêutico. Assim, é nos meandros da pessoalidade como ser - psicólogo clínico, professor, interlocutor - com o outro que se insere esta investigação clínica-fenomenológica.

A seguir serão apresentadas breves notas biográficas de Edith Stein e seu método, o método fenômeno-estrutural e o estudo de casos em Eugène Minkowski, a fenomenologia da vida de Michel Henry. Em seguida discorrerei sobre as modalidades clínicas refletidas nessas perspectivas. 
Capítulo 3: Autores e Métodos fenomenológicos 


\subsection{Edith Stein (1891-1942)}

Edith Theresa Hedwing Stein nasceu em 12 de outubro de 1891 em Breslau, então Polônia, hoje Alemanha. Filha menor de cinco irmãs e dois irmãos, seu pai comerciante em madeiras - faleceu quando Edith tinha dois anos de idade. Sua mãe fez do negócio, que o pai deixara endividado, uma companhia de prestígio. Vinda de uma família hebraica de arraigadas convicções, na qual sua mãe levava uma vida de profunda piedade e grande fidelidade à lei, Edith se afastou, já em seus anos de estudante, da fé judaica.

Como estudante universitária se destacou diante dos colegas devido a seu extraordinário talento, porém afirmava que mais importante que ser inteligente era fazer o bem. Em Breslau e Göttinguen estudou letras germânicas, história e psicologia. Stein $^{2}$ (2002, p.297-298) afirmava seu interesse original: “..o que mais me atraía: quatro horas semanais de Introdução à Psicologia com William Stern ${ }^{3}$ e uma hora semanal de Filosofia da Natureza com Richard Hönigswald ${ }^{4}$. Os dois me admitiram já no primeiro semestre de seus seminários. O curso de psicologia foi realmente o primeiro que assisti. Isto poderia ser um sinal anunciador, já que os quatro semestres que estudei em Breslau foi a psicologia a que mais me dediquei. A explicação de Stern era simples e compreensível, e eu a seguia como uma hora de agradável conversação". Aqui observamos como a psicologia era um de seus grandes interesses. No entanto, desiludiu-se com ela por considerá-la "uma psicologia sem alma" e voltou seu interesse para a filosofia (Fermín ${ }^{5}, 2002$, p.23).

Para Stein (2002, p.330-331), "era um erro pensar em um trabalho psicológico. Todos meus estudos de psicologia me levaram ao convencimento de que esta ciência estava ainda em fraldas; que Ihe faltava o necessário fundamento de ideias básicas claras, e que esta mesma ciência era incapaz de elaborar esses pressupostos. Entretanto, o que até aquele momento conhecia da fenomenologia, me havia entusiasmado, porque consistia fundamental e essencialmente em um trabalho de

\footnotetext{
${ }^{2}$ Stein, E. (2002). Obras Completas. Vol. I. Escritos autobiográficos y cartas. Madrid: Editorial Monte Carmelo.

${ }^{3}$ William Stern (1871-1938), psicólogo e filósofo alemão, especialista da psicologia da criança e do adolescente.

${ }^{4}$ Richard Hönigswald (1875-1947), filósofo neokantiano, catedrático de filosofia em Breslau.

${ }^{5}$ Fermín. In: Introdução geral. Stein, E, (2000). Obras Completas. Vol. I. Escritos autobiográficos y cartas. Madrid: Editorial Monte Carmelo.
} 
esclarecimento, e porque desde o começo ela mesma havia forjado os instrumentos intelectuais que necessitava. Mas em meus começos de Gotinga sentia uma ligeira pressão a respeito de meu tema de psicologia, mas logo o rejeitei"

Uma das grandes características de Edith Stein era a busca apaixonada pela verdade. Desde cedo se perguntava pelo sentido mais profundo da existência humana. Essa indagação pelo humano enraizou e fundamentou seus estudos filosóficos. O método de Edmund Husserl Ihe permitiu elaborar seus preconceitos racionalistas. Após ler os escritos de Santa Teresa de Ávila encontrou ali algo que tanto procurava, na busca pela verdade. "Caiu em minhas mãos a 'Vida' de nossa Santa Mãe Teresa e colocou fim a minha larga busca pela verdadeira fé" (Stein, 2002, p.500). No verão de 1921 tomou a firme decisão de converter-se ao catolicismo e no dia 1 을 de janeiro de 1922 foi batizada.

Edith era apaixonada pelos acontecimentos políticos de seu tempo e sua profunda consciência de responsabilidade social a levou a defender a igualdade dos direitos da mulher. Ministrava aulas para trabalhadoras quando ainda estava no primeiro semestre da universidade e fez de sua profissão um ato de serviço comunitário.

Em 1915 interrompeu os estudos para iniciar seu aprendizado como auxiliar de enfermagem na Cruz Vermelha e trabalhou em um hospital de prevenção de epidemias. Sua preocupação para ajudar outro ser humano superou qualquer interesse intelectual da época, teve que deixar os estudos filosóficos para se voluntariar na Cruz Vermelha e, contra a opinião de sua mãe, dedicou-se ao serviço em um hospital militar.

Stein conheceu Edmund Husserl em 1913 e, após defender seu doutorado sob sua orientação, de 1916 a 1918, foi sua assistente e discípula em Friburgo de Brisgovia, na Alemanha. Paralelamente lecionou sobre a introdução à fenomenologia para estudantes universitários e publicou seus primeiros trabalhos sobre os fundamentos filosóficos da psicologia, a comunidade e o estado.

Nessa época não se aceitavam mulheres nas cátedras. Edith reuniu um grupo privado de estudos em Breslau e ministrou aulas na universidade popular, o jardim de 
infância da fenomenologia. Em 1932 foi nomeada para a cátedra de antropologia no Instituto Alemão de Pedagogia Científica de Münster; um ano mais tarde foi retirada do posto, por causa de sua ascendência judaica.

Após a ocupação alemã nos Países Baixos pelo regime de Adolf Hitler , começou na Holanda a perseguição aos judeus e a Gestapo aprisionou Edith Stein e sua irmã Rosa Stein, que trabalhava como porteira do Convento de Echt. Ambas foram deportadas para Auschwitz onde morreram nas câmaras de gás em 9 de agosto de 1942.

A obra de Edith Stein pode ser dividida em três períodos: o período fenomenológico, o período pedagógico e o período místico. Dentro do período fenomenológico, Edith estudou a fundamentação filosófica da psicologia e das ciências do espírito. Sua obra é vasta e densa.

Há um filme ${ }^{6}$ italiano que discorre sobre a vida de Edith Stein. Nele, uma passagem muito bonita descreve, de forma viva e não conceitual, o que é a fenomenologia. Na cena, a família Stein almoçava quando uma sobrinha pergunta "o que é essa tal de fenomenologia". Edith pergunta para a garotinha se ela quer saber o que é fenomenologia, levanta-se da mesa, pega a menina pelas mãos, a leva ao piano e fala: "Está vendo o piano? Neste momento ele é só um móvel como outro que usamos para apoiar os biscoitos, porém ele se torna aquilo para o que foi criado, quando alguém o abre e o toca, são as possibilidades que ele esconde que o tornarão vivo, mas quem tornará vivo? Sou eu! Porque sei que pode tocar música, sem a minha consciência e a sua consciência, este pobre piano estaria condenado a viver para sempre somente um apoio para os biscoitos" e a família aplaude a explicação, mostrando que captaram algo por 'compreensão empática'.

O filme toca muitos pontos importantes da Vida, citarei ${ }^{7}$ aqueles que me marcaram como o suicídio, o renunciar a si mesma, a paixão, a proibição para que os judeus lecionassem em 1933, a filosofia como procura da verdade, a intuição: a mente não produz a verdade, mas a encontra, a história nem sempre está do lado da verdade

\footnotetext{
${ }^{6}$ Filme: A Sétima Morada. (2006). DVD. Paulinas Multimídia. Produção: Itália, França, Hungria, Polônia.

${ }^{7}$ As citações são referências à dublagem em português realizada no filme $A$ Sétima Morada.
} 
e da razão, o não alinhamento ao poder de Edith Stein, o nazismo como ilusão absurda: quanto dura o pesadelo do nazismo? A alma da criança é como argila, toma a forma que Ihe dão, o segredo inexplicável: no Carmelo de Colônia uno Deus à Alma, não consigo explicar, é o meu segredo; não se vem ao Carmelo para fugir, mas por vocação, o silêncio, o mistério da existência, o perigo da vaidade: o contrário da humildade: se queres ser tudo, não deseje ser nada, e em todo lugar há sofrimento.

Essa breve apresentação da biografia de Edith Stein se coaduna com a perspectiva humana que experiencio na vida e com a psicologia comecei a me aprofundar em uma compreensão menos intelectual e racional das experiências de sofrimento humano recolhidas no convívio com meus pacientes, alunos, orientandos, colegas de trabalho no cotidiano.

\subsection{O método fenomenológico a partir de Edith Stein}

A fenomenologia de $\operatorname{Stein}^{8}$ (2007, p.33) se baseia em seu mestre Edmund Husserl e procura "fixar nossa atenção nas coisas mesmas e ir construindo sobre essa base na medida em que possamos". Há dois princípios básicos na fenomenologia, o mais fundamental segundo Stein é esse primeiro: fixar a atenção nas coisas mesmas. E o segundo: dirigir o olhar ao essencial.

Para o psicólogo clínico essas bases do método fenomenológico são extremamente úteis para compreender nosso semelhante, um humano desconhecido, auxiliando-nos a conhecer algo do Homem que está diante de nós, por meio de um caminho, de um método. Fora da vida científica, não é necessário utilizar qualquer método para estudar o humano mas, dentro da ciência humana, sim.

$\mathrm{Na}$ fenomenologia de Edith Stein encontro a fecundidade para rever criticamente a clinica experienciada. De modo que essa articulação entre duas disciplinas tão distintas quanto próximas, como a psicologia e a filosofia

\footnotetext{
${ }^{8}$ Stein, E. (2007). La estructura de la persona humana. Madrid: Estudios y ensayos BAC Filosofía y Ciencias.
} 
fenomenológica, não poderia ser realizada sem nos atermos aos fundamentos da vida humana, tal como a vivemos e não como a pensamos. Stein $\left(2007\right.$, p.33) ${ }^{9}$ afirma:

"Não interrogar as teorias sobre as coisas, deixar fora enquanto seja possível o que se tem ouvido ou lido e as composições de lugar que a gente mesmo fez, para, melhor, aproximar-se das coisas com um olhar livre de prejuízos e beber da intuição imediata. Se queremos saber o que é o homem, temos que nos colocar de modo o mais vivo possível na situação na qual experimentamos a existência humana, quer dizer, o que dela experimentamos em nós mesmos e em nossos encontros com outros homens. Tudo isso soa muito a empirismo, mas não o é, se é que por 'empirismo' se entende somente a percepção e a experiência de coisas particulares. De fato, o segundo princípio reza assim: dirigir o olhar ao essencial. A intuição não é somente a percepção sensível de uma coisa determinada e particular, tal como é o aqui e agora. Existe uma intuição do que a coisa é por essência, e isto pode ter por sua vez um duplo significado: o que a coisa é por seu ser próprio e o que é por sua essência universal. $O$ ato em que se capta a essência é uma percepção espiritual, que Husserl denominou intuição. Reside em toda experiência particular como um fator que não pode faltar, pois não poderíamos falar de homens, animais e plantas se em cada 'isto' que percebemos aqui e agora não captássemos algo de universal. Mas a intuição também se pode separar dessa experiência particular e ser efetuada por si mesma".

Husserl elaborou e empregou pela primeira vez o método fenomenológico no tomo II de suas Investigações Lógicas. O princípio fundamental deste método é fixar $\boldsymbol{a}$ atenção nas coisas mesmas. Algumas premissas são rigorosamente seguidas, tais como a de não fazer interrogações teóricas sobre as coisas, não usar o que se tenha ouvido ou lido sobre o fenômeno a estudar, aproximar-se das coisas livre de preconceitos, para beber da intuição imediata. Em acordo com Stein (2007)', se queremos saber quem é o homem, teremos que nos colocar de modo o mais vivo possível na situação experimentada em nós mesmos da existência humana, o que dela experimentamos em nossos encontros.

\footnotetext{
${ }^{9}$ Nossa tradução.
} 
O segundo princípio do método fenomenológico é dirigir-se ao essencial. Em toda ação humana existe uma intuição do que a coisa é por essência, e isto tem dois significados: o que a coisa é por seu ser próprio e o que é por sua essência universal. 0 ato que capta a essência é uma percepção espiritual ou intuição. Intuição da essência singular e comunitária do ser humano.

A intuição na fenomenologia só ocorre na corporeidade, na sensibilidade, no olhar, no sentimento e na posterior reflexão, é captar o vivido na área não representacional, sendo por isso a origem e o fundamento do pensamento posterior.

A estrutura da pessoa humana é compreendida por Edith Stein de forma tripartida: corpo, psique e espírito. Essas dimensões da estrutura da pessoa humana, em dimensões corpóreas, psíquicas e espirituais, se relacionam entre si, há movimento e dinamismo entre elas, bem como uma profundidade fenomenológica útil à psicologia clínica, nos seus aspectos temporais e espaciais.

É a corporeidade o que nos dá a constituição do ser que nos localiza, faz referência ao objeto físico e ao espaço. O espaço em fenomenologia se refere ao espaço vivido na clínica e está na base de todos os conceitos de espaço, distinto do espaço geométrico e idealizado da física.

A dimensão psíquica não conta com um controle consciente, refere-se aos impulsos, às emoções. Já o registro dos atos do corpo é um terceiro momento, que supera a interioridade e a exterioridade, e possibilita ter consciência das coisas. Podese controlar o corpo e a psique, porém esse registro do ato de controle não é de ordem psíquica ou corpórea, mas de ordem espiritual (Ales Bello $\left.{ }^{10}, 2006\right)$.

Husserl usava a palavra espírito porque, na filosofia que o antecedeu, o que não era corpo era considerado da ordem da alma. Ele analisava a alma em duas partes: (a) uma formada por atos de caráter psíquico, cujo representante é o impulso psíquico não desejado ou incontrolável. Não somos nós as origens desses impulsos, nem nós que os provocamos, mas os encontramos. Se sentirmos um grande rumor, todos terão medo, e o medo não vem desejado por nós, ele é uma reação e acontece, essa é a

\footnotetext{
${ }^{10}$ Ales Bello, A. (2006). Introdução à fenomenologia. Tradução Ir. Jacinta Turolo Garcia e Miguel Mahfoud. Bauru: São Paulo: Edusc.
} 
parte psíquica. (b) A outra parte é a que reflete, decide e avalia, e está ligada aos atos da compreensão, da decisão, da reflexão, do pensar, sendo denominada de espírito. Todo ser humano tem potencialmente essas três características, umas mais, outras menos desenvolvidas (Ales Bello, 2006).

Os sujeitos acontecem em três distintos graus de presença e realização das suas atividades. Primeiro, há pessoas que alcançam alto grau de desenvolvimento da estrutura comum a todo ser humano, ou seja, uma plena atividade corpórea, psíquica e espiritual, e se mostram sujeitos educados, corpórea, psíquica e espiritualmente. 0 segundo grau representa um baixo grau de desenvolvimento espiritual e traz dificuldade para refletir, avaliar, decidir e controlar-se. O resultado é a dificuldade para controlar os impulsos e as emoções, típico de alguém pouco educado espiritualmente. Já a impossibilidade de realizar plenamente a estrutura humana mostra alguém com pouca realização da estrutura comum, típica em estados de coma. Ales Bello (2006) se refere à estrutura universal do ser humano; no entanto, do ponto de vista psicopatológico, essa compreensão se torna ainda mais complexa.

Assim, temos a dimensão do corpo que veicula os atos corpóreos, nos quais encontramos os instintos em geral, como a fome e a sede, comuns a todos os seres humanos; a segunda dimensão, composta pelos atos psíquicos, inclui as reações emocionais, os impulsos para beber e comer; e a terceira dimensão é composta pelos atos espirituais, que é constituída pelos atos de reflexão, tomada de decisão, avaliação e controle. Esse resumo, quando pensado à luz da psicopatologia, contribuiu para que pudéssemos compreender de outro modo o sofrimento humano, para além dos sintomas observados e os critérios de evidências das ciências naturais.

Conhecemos essas três dimensões porque temos Consciência. Esta não é um lugar físico, nem um lugar específico, nem é de caráter espiritual ou psíquico, a consciência é um ponto de convergência das operações humanas que nos permite dizer o que estamos dizendo ou fazer o que estamos fazendo. Assim somos conscientes da realidade corpórea, da atividade psíquica e de uma atividade espiritual. Nós temos consciência de que registramos esses atos. A distinção destes atos ocorre intuitivamente (Ales Bello, 2006). 
Todos os seres humanos têm potencialmente a mesma estrutura humana, embora não a ativem da mesma maneira e não tenham os mesmos conteúdos, seja do ponto de vista psíquico ou do ponto de vista espiritual. Assumindo essa hipótese, as dificuldades ocorrem porque existem diferenças.

Como exemplos, há pessoas que podem ouvir e outras não, existem aquelas que podem ver e outras não, e podemos conhecer suas subjetividades. Essa elucidação que a estrutura do ser humano é universal é importante para a aplicação clínica a cada pessoa, tomada singularmente. Isso significa que registramos atos psíquicos, como os impulsos que movimentam o homem para fora ou para dentro. Com este saber, o psicólogo pode compreender algo que uma pessoa específica está vivendo (Ales Bello, 2006).

Ales Bello (2006) indaga que no campo da Psicologia, Psiquiatria ou Psicopatologia, ao considerar a complexidade do ser humano, como corpóreo, psíquico e espiritual, é preciso indagar o que é a psique. A Psicologia, como área de estudo da psique, pode ou não cobrir este vasto campo definido como espiritual?

Um ato muito importante na obra de Edmund Husserl e de Edith Stein é o ato da empatia ou entropatia. De acordo com Ales Bello (2006, p.63) "sua peculiaridade é a de sentirmos imediatamente que estamos em contato com outro ser humano, de modo tal que podemos falar "nós". (...) Podemos afirmar que os atos nunca se dão isoladamente, pois junto com o ato perceptivo está esse ato específico da entropatia, que é um apreender o outro, e essa apreensão é imediata. (...) Note que se trata de semelhança e não identidade, pois eu percebo que somos dois, que o outro não é idêntico, mas semelhante a mim".

É interessante que a palavra empatia, que vem da palavra alemã Einfühlung (que Husserl usava) é composta por três partes. O núcleo fühl significa "sentir". A palavra grega pathos poderia corresponder a fühl, e significa "sofrer" e "estar perto". "A palavra empatia é uma tentativa de tradução desse sentir em termos linguísticos espontâneos do ser humano, para sentir o outro" (Ales Bello,2006, p.65) e não deve ser confundida com simpatia ou antipatia, que seriam reações psíquicas, mas 
referentes a uma vivência anterior. Por meio da entropatia penetramos no mundo intersubjetivo.

Edith Stein - fiel ao pensamento de Husserl - desenvolve uma caracterização do método fenomenológico em sua tese de doutorado sobre empatia ou intropatia, úteis para a clínica e para conhecer uma faceta da terceira dimensão, a espiritual. O método fenomenológico é importante para a clínica, pois fixa a atenção nas coisas mesmas e dirige o olhar ao essencial.

\subsection{Eugène Minkowski (1885-1972)}

Eugène Minkowski, nascido em São Petersburgo, é originário de uma família polonesa. Seu pai, Augusto, foi a São Petersburgo em sua juventude e enriqueceu com o mercado de sementes. Voltou a Varsóvia e casou-se com Tekla Lasecka. Dessa união nasceram cinco filhos, uma menina faleceu muito jovem e ficaram Mietek, Eugène, Paul e Anatol. Em 1905, os dois primeiros começaram a estudar medicina na Faculdade de Varsóvia.

Allen $^{11}$ (2000, p.15-24) fez importantes observações na biografia de Minkowski. "Devido à ocupação estrangeira, os cursos se davam em russo, mas por causa da derrota da flora czarista durante o conflito russo-japonês, teve lugar em Varsóvia uma manifestação importante a favor do retorno do idioma polonês na Universidade. Os participantes foram rodeados pela polícia montada, que tomou seus nomes. Entre eles, Mieteck e Eugène receberam um "antidiploma" que os proibia de realizar estudos no seio do Império russo". Em consequência dessa proibição, o irmão maior parte para Munique, e logo para a universidade alemã de Breslau.

Eugène partiu também para Munique e terminou em 1908 seu primeiro curso em medicina. No ano seguinte, os dois irmãos foram a Kasan, na Rússia, onde os cidadãos russos que terminaram seus estudos no estrangeiro podiam apresentar-se para um exame. Por volta de 1911/1912, Eugène vai a Zurique e se hospeda na casa de

\footnotetext{
${ }^{11}$ Allen, D.F (2000). Apresentação. In: Minkowski, E. La esquizofrenia. México: Fondo de Cultura Económica (Originalmente publicado em 1927).
} 
seu irmão. Françoise Minkowska ${ }^{12}$ (1882-1950) o ajuda a trabalhar como assistente, mal remunerado, do Dr. Eugen Bleuler.

Até março de 1915, incorpora-se como voluntário ao exército francês, como parte de uma equipe que buscava os feridos no front. Condecorado várias vezes, adota a França para residir e trabalhar. Apresenta e defende em 1926 uma tese em medicina sobre a perda do contato vital com a realidade na esquizofrenia, como sendo a essência dessa enfermidade.

Ao começar a segunda Guerra Mundial, Minkowski tinha 54 anos e é descrito por Allen (2000, p.16) como tendo conservado 'nervos sólidos' e uma tranquilidade que lhe permite dominar a ansiedade e atuar. A polícia de Vichy toca em sua porta em 1943. Minkowski foi libertado graças a sua filha, liberada pelos jovens soldados e rapidamente entrou em contato com o Dr. Michel Cenac.

Em um fascículo de Paris intitulado Du temps de l'étoile jaune (1945), Minkowski escreveu sobre sua vivência nessa época, (Allen, 2000, p.17): “Em 23 de agosto de 1943, os inspetores da polícia para assuntos judaicos se apresentaram em nosso domicílio para nos arrastar. Fomos denunciados por não portar a estrela. (...) Os inspetores eram muito jovens e começaram a declarar que, na qualidade de antissemitas, cumpriam com zelo sua missão. Nossa sorte parecia determinada. Drancy $^{13}$ e a deportação, sofrimentos que não tem nome. [...] Ainda vejo minha esposa de joelhos, rezando, implorando a Deus. [...] uma chamada por telefone da Prefeitura informou que nos libertariam".

Minkowski era modesto: "O trabalho de salvamento que me foi dado realizar [...] o fiz sob o signo da sociedade OSE que tive a honra de presidir [...] de 1933 a dezembro de 1944. OSE não significava Obra de Socorro a Crianças, como hoje em dia se tomou costume de interpretá-lo senão (jamais temos que esquecer o passado, e menos ainda negá-lo) as iniciais de origem russa da Sociedade de Proteção da Saúde das populações judias. [...] Antes do desastre de junho de 1940, pudemos desalojar da

\footnotetext{
${ }^{12}$ Françoise Minkowska nasceu em Moscou, faleceu em Paris. Foi membro da Société de l'Évolution Psychiatrique. Especialista no método de Rorschach, epilepsia, esposa de Eugène Minkowski e amiga de Ludwig Binswanger.

${ }^{13}$ Campo de concentração para presos políticos de 1941 a 1944.
} 
zona sul todas as crianças dos impérios centrais que tinham encontrado albergue em nossas casas das vizinhanças de Paris [...] Por fim, entre os dirigentes, me encontrei só. [...] mais de duas mil crianças, sem falar dos adultos, puderem ser salvos pela OSE, zona sul, das perseguições [...] mais de trinta assistentes sociais e empregados da OSE [...] foram deportados" (In Allen, D.F, 2000, p.17-18).

Minkowski foi um dos iniciadores da psicopatologia fenomenológica, ao lado de seu amigo Ludwig Binswanger (1881-1996) e de Karl Jaspers (1883-1969), todos reconhecidos como aqueles que iniciaram os estudos fenomenológicos em psicopatologia. Por intermédio de Françoise Brokman (1882-1950), psiquiatra, Minkowski conhece Eugene Bleuler (1857-1939) que estava conceituando a esquizofrenia e consegue na Clínica de Burghölzli, na Suíça, um cargo de assistente, onde trabalharam Jung, Binswanger e Abraham.

Ainda jovem psiquiatra, Minkowski estudou filosofia e a obra de Edmund Husserl (1859-1938) e se interessou pelo conceito de élan vital de Henry Bergson (1859-1941). Tão interessado pela filosofia, por pouco não abandona a medicina (Minkowski, 1933/1995). Mas o contato com o sofrimento humano no ambiente psiquiátrico e o de guerra o fez mudar de ideia, viu amigos morrendo nas trincheiras. Casa-se com Françoise Brokman, que trabalhava com o método de Hermann Rorschach (1884-1922), porém morre prematuramente em 1950. Em homenagem às investigações de Minkowska, em 1956 foi publicado o Le Rorschach com prefácio de Eugène Minkowski.

A partir dos estudos de seu marido, Minkowska investigou profundamente a linguagem, tal como ele a recolhia no discurso do pacientes esquizofrênicos. A partir da semântica pessoal do paciente, Minkowski se aproximava do modo de ser do outro e desenvolve as noções de espaço e tempo vividos, chamando a atenção para os mecanismos essenciais da linguagem, o mecanismo de corte e o mecanismo de ligação, bem como a expressão, a afetividade e o mecanismo de compensação fenomenológica. 
Segundo Follin ${ }^{14}$ (2000), Eugène Minkowski participou, no verão de 1940, na França, de todas as sessões sobre o método das manchas de tinta de Hermann Rorschach coordenadas por Françoise Minkowska. A prova de Rorschach era utilizada como meio de advertir a presença no mundo material da vivência do doente e seu modo de compreender as realidades objetivas. Para Minkowski ${ }^{15}$ (1952), tanto Françoise Minkowska como Hermann Rorschach seguem o mesmo caminho: o estudo do mundo das formas. Eugène Minkowski morreu em $1972^{16}$ e seu enterro foi assistido por muitos, incluindo Henri Ey.

Em nosso país, alguns autores têm dialogado com a obra de Eugène Minkowski. Queluz $^{17}$ (1989) abordou a expressão verbal de vinte crianças da pré-escola em uma abordagem fenomenológica, na qual se ancora no trabalho da vivência temporal de Minkowski.

A partir da vertente da Psicopatologia Fundamental, Pereira ${ }^{18}$ (2000) afirma que Minkowski "buscou constituir uma psicopatologia não especulativa, baseada numa rigorosa abordagem fenomenológica da experiência clínica e numa postura éticocientífica resolutamente humanista" (p.155). Na perspectiva fenomenológicoexistencial, Forghieri ${ }^{19}(2004,2007)$ tem citado a obra de Minkowski frente à necessidade de alternar a racionalidade com a vivência imediata e pré-reflexiva e o livro Le temps vécu tem influenciado, em parte, seu trabalho sobre aconselhamento terapêutico.

\footnotetext{
${ }^{14}$ Follin, S. (2000). Prólogo. In: Minkowski, E. La esquizofrenia. (2000). México: Fondo de Cultura Económica.

${ }^{15}$ Minkowski, E. (1952). Le Rorschach dans I'oeuvre de Françoise Minkowska. In: Eugène Minkowski et Zéna Helman (1965). Cahiers du groupe Françoise Minkowska, 115-117.

${ }^{16} \mathrm{http}: / /$ en.wikipedia.org/wiki/Eug\%C3\%A8ne_Minkowski

17 Queluz, A. G. (1989). A vivência temporal na fala de crianças de pré-escola: uma abordagem fenomenológica. Tese de doutorado. São Paulo: Instituto de Psicologia, 268 p.

${ }^{18}$ Pereira, M. E. C. (2000). Minkowski ou a psicopatologia como psicologia do pathos humano. Rev. Latinoam. Psicop. Fund. III, 4, 143-155.

${ }^{19}$ Forghieri, Y. C. (2007). Aconselhamento terapêutico. Origens, fundamentos e prática. São Paulo: Thomson. Forghieri, Y. C. (2004). Psicologia Fenomenológica: fundamentos, método e pesquisa. São Paulo: Pioneira Thomson Learning.
} 
Silva Neto ${ }^{20}$ (2004) investigou pormenorizadamente a história do desenvolvimento dos conceitos da psicopatologia por Eugène Minkowski, das práticas de psicoterapia e da clínica psiquiátrica do século vinte. Nos últimos dez anos, na França, com o surgimento de novas edições de todos os livros de Minkowski e novas coletâneas de artigos raros, o interesse por seu pensamento foi renovado. $\mathrm{O}$ autor afirma que nenhum de seus livros jamais foi traduzido no Brasil e afirma que a obra de Minkowski oferece uma sólida base para uma psicologia a ser desenvolvida no século XXI.

No primeiro livro publicado por psicólogos no Brasil sobre a Psicopatologia fenômeno-estrutural, Villemor-Amaral \& Yazigi ${ }^{21}$ (2010, p.19) afirmam: "é famoso o estudo de Minkowska 22 (1949) sobre os pintores Van Gogh, epiléptico, e Seurat, esquizo-racional, em que, contrapondo-os, coloca à luz as características dos dois tipos de estrutura mental nas manifestações plásticas. No polo epilepto-sensorial, o movimento dá vitalidade às formas, a cor tem tom afetivo, os objetos se tocam, linhas sobem e descem, os traços são lançados em formas de hachuras. Já no polo esquizoracional, predomina a imobilidade, a precisão geométrica, a preponderância da forma sobre o movimento, a cor pobre ou inadequada, os objetos separados, isolados ou fragmentados (Helman $\left.{ }^{23}, 1959\right)$ ".

As referências de Minkowski eram Husserl, Jaspers, Bergson, aprendeu com Bleuler, respeitou Freud. Ele foi um dos membros fundadores da revista L'Évolution psychiatrique em 1925. As ideias de Minkowski chegam aos Estados Unidos em 1958 por intermédio do livro Existência de Henri Ellenberger e Rollo May. Este livro foi dedicado a Minkowski e Binswanger. No final dos anos 50, Ronald Laing, no livro O Eu

\footnotetext{
${ }^{20}$ Silva Neto, N. A. (2004). A atualidade da Obra de Eugène Minkowski (1885-1972). Bol-Acad.Paul. Psicol. 24 (2): 50-62.

${ }^{21}$ Villemor Amaral, A.E.; Yazigi, L.(Orgs.) (2010). Psicopatologia fenômeno-estrutural. São Paulo: Casa do Psicólogo.

${ }^{22}$ Minkowska, F. (1949). De Van Gogh et Seurat aux dessins d'enfants. Paris: Presses du Temps Présent. In: Yazigi, L. (2002) Two styles of mental functioning and literary language: a phenomenological psychological reading of A. Machado and C. Cavafy. A tribute to Zena Helman. Psic.: Teor. $e$ Pesq., Brasília, v. 18, n. 3.

${ }^{23}$ Helman Z. (1959). La pousée sensori-motrice. Bruxelles: Charles Dessart; 1971.
} 
dividido, cita Minkowski, desde a epígrafe às referências bibliográficas, da Equizofrenia e do Tempo Vivido, entre outros artigos. Afirma que Minkowski foi o primeiro na história da psiquiatria a tentar uma séria reconstrução da experiência vivida pelo outro, em favor de uma relação desalienante com o paciente" (Allen, 2000, p.23-24).

Granger $^{24}$ (2002) afirma que Minkowski e seu amigo Binswanger (1881-1966) foram os criadores da fenomenologia psiquiátrica no dia 25 de novembro de 1922 na Sociedade Psiquiátrica Suíça. Foi influenciado por Husserl, Bergson, Max Scheler e Martin Buber e defendia uma concepção antropológica em todos os seus escritos e como aplicou à prática clínica. Além de seus principais livros: A Esquizofrenia (1927), O tempo vivido (1933), Para uma cosmologia (1936), Tratado de psicopatologia (1966), tem cerca de 250 artigos científicos publicados em revistas científicas.

Assim, vemos o aspecto humano de um médico preocupado pela humanidade, tentando escrever um novo capítulo na psicopatologia. Minkowski demonstrou muita solidariedade pela humanidade ao defender na clandestinidade centenas de pessoas, perseguidos pelo nazismo na França. Chamava a atenção para os sentimentos e os afetos.

\subsection{O método fenômeno-estrutural de Eugène Minkowski}

O método fenomenológico, segundo Binswanger ${ }^{25}$ (1973) - amigo de Minkowski e de Freud - deve ser compreendido a partir de dois grandes domínios: da ciência natural e da fenomenologia. Na ciência tudo deriva da percepção sensória, exterior ou interior, e se constrói sobre ela; na fenomenologia, pelo contrário, deriva da visão categorial ou visão essencial. A fenomenologia trata de fenômenos, tipos ou figuras da consciência que não são próprios de natureza alguma, mas que possuem uma essência captável por uma visão imediata. Deixa-se de lado a teoria e volta-se à intuição, que lida com a pura e simples observação dos fenômenos, vale o que vemos por visão categorial ou sensória, tem o mérito de não confundir o observado com teorias, por melhor fundadas que sejam.

\footnotetext{
${ }^{24}$ Granger, B.(2002). Présentation. In. Minkowski, E. Écrits Cliniques. Textes rassemblés par Bernard Granger. Ramonville Saint-Agne.

${ }^{25}$ Binswanger, L. (1973). Artículos y Conferéncias Escojidas. Madrid: Gráficas Condor.
} 
O aspecto metodológico aplicado à clínica leva em consideração o caráter esquizoide ou sintônico das manifestações psíquicas dos pacientes, tal como Eugen Bleuler observara. Para Minkowski (1927/2000, p.79), “as noções de esquizoidia e de sintonia apontam ao comportamento do indivíduo com respeito ao ambiente, sua faculdade de vibrar em uníssono com ele e de manter-se em contato com a realidade. Essas noções se referem então, antes de tudo, à afetividade e à atividade do sujeito".

Para apreciar a afetividade e as atividades dos sujeitos "levamos em nós noções de um instrumento infalível. É nossa própria esfera afetiva, nossa personalidade" (Minkowski, 1927/2000, p.79). Há uma objetividade nesse método, porém não aquela objetividade das ciências naturais; sobre os aspectos metodológicos, o psicopatólogo afirma: "Na vida, quando se trata de apreciar a um de nossos semelhantes, não nos contentamos em enumerar suas razões unicamente. Deixamo-nos guiar também por nossa intuição que tenta penetrar (pénetration) a personalidade do outro, por meio das sensações de frio e de calor que experimentamos em sua presença, por nossa faculdade de fazer nossos seus sentimentos e suas reações, de colocar-nos em seu diapasão, de 'compreendê-lo', no sentido 'sentimental' ou, melhor, irracional da palavra. E em nosso juízo sobre ele, estes últimos fatores intervirão tanto, ou mais, que os primeiros e lhe conferirão também uma certeza".

Aqui Minkowski se refere aos nossos semelhantes. Diante de um alienado, com o qual "nós colocaremos em jogo nossa personalidade viva, e mediremos, confrontando-o com ela, o caráter particular da maneira de ser do nosso doente. Além de nossa razão, faremos intervir nosso sentimento, o que desde logo não quer dizer que teremos piedade da sorte de nosso paciente, senão que tentaremos sentir com ele e ver como sente. O resultado dessa prova constituirá um elemento importante de nosso juízo psiquiátrico a respeito dele" (Minkowski, 1927/2000, p.79-80).

O elemento afetivo é um instrumento valioso e é um elemento adicional àqueles que aparecem em forma de sintomas. Para Minkowski, tal elemento não diminui em nada o papel dos sintomas observados pelo diagnóstico realizado racionalmente e agora acrescido do diagnóstico pelo sentimento ou por compenetração que, por vezes - afirma - será o mais importante. É evidente que o 
diagnóstico por compenetração em nenhum caso poderia ser rebaixado a um diagnóstico por simples impressão (Minkowski, 1927/2000, p.80). O método que Minkowski expõe exige, como qualquer outro método, ser aprendido e se adquire por meio de uma larga experiência clínica e psicopatológica.

Minkowski ${ }^{26}$ (1923/1970) valoriza o contato direto com o doente como foco de suas investigações. O contato pessoal é indispensável em sua perspectiva psicopatológica e humanista, porque é ele que revela a presença da essência do outro. Como exemplo cita o caso de um paciente alienado do convívio social como sendo excluído da comunidade na qual vive. Esse relato de Minkowski é considerado o precursor da análise fenomenológica no campo psicopatológico.

Minkowski apresentou na 63ạ Assembleia da Sociedade Psiquiátrica Suíça o atendimento a um paciente de 66 anos diagnosticado com esquizofrenia e melancolia. Ele conviveu dois meses, dia e noite, com esse senhor. Momentos difíceis de suportar, nos quais reconhecia a impossibilidade de ser médico durante vinte e quatro horas por dia. Esta relação terapêutica abriu caminho à análise fenômeno-estrutural, descrita no Tratado de Psicopatologia por ele elaborado e que condensa a maior parte de sua obra (Minkowski $^{27}$, 1966/1999).

Neste ensaio, Minkowski (1923/1970) detecta o desacordo de duas melodias humanas - a do terapeuta e a do paciente - que se confrontam a maior parte do tempo e apresentam a estrutura do tempo vivido em cada um deles. No paciente, o tempo se fragmenta e ele perde a ressonância no contato com o outro, sua vida perde o colorido. O devir do paciente está barrado por suas ideias delirantes. O passado o imobiliza pelas ideias de culpa, o tempo presente aparece sob a forma de ideias indignas de ruína. Em nós terapeutas - afirmava Minkowski - o devir está em aberto,

\footnotetext{
${ }^{26}$ Minkowski, E. (1970). Estudio psicologico y analisis fenomenologico de un caso de melancolia esquizofrenica. In: Minkoski, E; Von Gebsattel, V.E ; Strauss, E.W. Antropologia de la alienación. Caracas, Venezuela: Monte Avila Editores. (Originalmente publicado em 1923).

${ }^{27}$ Minkowski, E. (1999). Traité de Psychopathologie. Paris: Collection Les Empêcheurs de penser en rond. (Originalmente publicado em 1966).
} 
já no paciente, fechado. De qualquer modo o outro é compreendido como um ser diferente e semelhante e não um doente (Minkowski $\left.{ }^{28}, 1933 / 1995\right)$.

Minkowski $^{29}$ (1965) elabora uma compreensão psicopatológica própria e original. Seus principais interlocutores foram Husserl, Bergson e Karl Jaspers. Para Minkowski, o sofrimento nos coloca em presença do destino humano, nos atravessa e nos aproxima do vivido. O sofrimento humano, a solidariedade inter-humana, o movimento de simpatia no olhar ou num simples aperto de mão, o compartilhar com alguém, são movimentos espontâneos que estão nas raízes da vida afetiva.

Ao apresentar seus estudos sobre a perda do contato vital com a realidade em pacientes esquizofrênicos, concomitantemente com o racionalismo mórbido, o pensamento matemático ou espacial, a lógica coisificada, Minkowski ${ }^{30}$ (1927/1953) trouxe uma nova compreensão para a pessoa com esquizofrenia, diferente daquela que privilegia as alterações do pensamento de seu mestre Eugen Bleuler.

A partir do élan vital ou ímpeto vital de Bergson, Minkowski (1927/1953) sustenta que o fundo do processo esquizofrênico é a perda do contato vital com a realidade, a perda do contato dinâmico com a vida e com tudo aquilo que dá uma condição viva à relação do sujeito com os demais.

A necessidade de compreensão humana é cara a Minkowski (1966/1999) e ele busca penetrar em mundos fechados ou ao menos saber os motivos de sua inacessibilidade. Com esforço de compenetração e compreensão, a afetividade ou sua deficiência podem ser apreciadas, não só em sua origem ou causa, mas como parte da existência humana. Há indivíduos que vibram em uníssono com o ambiente e mostram boa afetividade e sintonia, outros são racionais, distantes e mais frios, nos quais os fatores intelectuais e racionais reinam. Um tipo racional não é superior a um tipo sensorial, mas cada tipo tem seus recursos e suas fraquezas (Minkowski, 1965).

\footnotetext{
${ }^{28}$ Minkowski, E. (1995). Le temps vécu. Paris : Press Universitaires de France. (Originalmente publicado em 1933).

${ }^{29}$ Minkowski, E. (1965). Recueil d’articles 1923-1965. In: Eugène Minkowski et Zéna Helman (Orgs.). Cahiers du groupe Françoise Minkowska. $\mathrm{n}^{\circ} 15$.

${ }^{30}$ Minkowski, E. (1953). La shizophrénie. Psychopathologie des schizoïdes et des schizophrènes. 2ème éd. France: Desclée de Brouwer (Originalmente publicado em 1927).
} 
Há um princípio de duplo aspecto no método fenomenológico, que é indireto, já que ocorre em dois tempos, antes e depois correm paralelamente. Os fenômenos constitutivos da vida determinam a forma, tal como a forma do sofrimento moral, das ideias delirantes de culpa, de ruína, de indignidade e de morte brutal. Todo sentido da vida está ligado ao tempo e ao espaço vividos (Minkowski, 1966/1999).

Um conceito fundamental na fenomenologia é a noção de compensação fenomenológica (Minkowski, 1966/1999), fator positivo e de equilíbrio. Quando há uma falha ocorre uma descompensação na personalidade. Todo ser compensa uma dificuldade que se impõe. Como exemplo, a deficiência do fator intuitivo-afetivo pode ser compensada em parte pela inteligência. Um homem pode se refugiar em seu mundo imaginário, em seus castelos, em detrimento de um contato mais próximo com a realidade, de modo que o mundo imaginário substitui o real. Uma ruptura se produz e surgem mecanismos de compensação frente a sentimentos de inferioridade (Minkowski, 1965).

O importante papel da linguagem reside como sistema de referência, chamado a revelar os caracteres essenciais de ordem formal da vida humana, suas manifestações normais e patológicas (Minkowski ${ }^{31}$, 1952). É então observada a fenomenologia da linguagem em sua função expressiva, a qualidade do espaço e do tempo vivido pelos pacientes, sua capacidade de empatia e a ressonância no encontro com os outros.

Os mecanismos de ligação (lien) e corte (coupure) observados na linguagem e revelados pelo método das manchas de tinta de Rorschach, respectivamente característicos da linguagem dos quadros clínicos de epilépticos e esquizofrênicos, constituem a base da tipologia de Françoise Minkowska ${ }^{32}$ (1956), núcleo da noção de estrutura da psicopatologia fenômeno-estrutural, que se oferece como base para a explicação das relações do indivíduo com o mundo.

\footnotetext{
${ }^{31}$ Minkowski, E. (1952). Le Rorschach dans l'oeuvre de françoise Minkowska. In : Eugène Minkowski et Zéna Helman (1965). Cahiers du groupe Françoise Minkowska, 115-117.

32 Minkowska, F. (1978). Le Rorschach. A la recherche du monde des formes. France: Desclée de Brouwer. (Originalmente publicado em 1956).
} 
A ligação que estrutura a atitude do sujeito no espaço e no tempo tende a manter juntas as partes separadas. Em detrimento do contorno formal que isola as figuras, o movimento é indissociável da ligação que dá unidade estrutural na epilepsia. Este fato contrasta com a ausência de cinestesia no esquizofrênico que, com frequência, faz uso de termos como separado, partido, fragmentadoe que têm relação com o mecanismo essencial da esquizofrenia, a Spaltung. ver

Ao revelar a perda do contato vital com a realidade em pacientes esquizofrênicos, o racionalismo mórbido, o pensamento matemático ou espacial, a lógica coisificada, Minkowski trouxe uma nova compreensão da esquizofrenia, diferente daquela de seu mestre Bleuler, que também pode ser observada em outros quadros psicopatológicos.

Minkowska $^{33}$ foi a primeira a analisar a pintura de Van Gogh na perspectiva fenomenológica e apresentou seu estudo no primeiro congresso mundial de psiquiatria realizado em Paris em 1949. Ela observava seu traçado, os movimentos, o uso do espaço, as ligações e as relações com a psicopatologia da epilepsia nas crianças.

A prevalência da observação e da descrição refinada revela elementos da linguagem e da subjetividade, compreendendo que a objetividade não pode se estabelecer em ausência da subjetividade que a ela concerne. Nesse contexto, o uso de desenhos ultrapassa a caracterização de indicadores psicométricos, pois valoriza o traço singular e pessoal na clínica e suas implicações no campo do humano.

Françoise Minkowska ${ }^{34}$ (1933/2007) apresentou uma análise da pintura de Van Gogh em uma perspectiva fenomenológica no primeiro congresso mundial de psiquiatria realizado em Paris no final da década de 40. Ela observara seu traçado, os movimentos, o uso do espaço, o mecanismo de ligação, a espiritualidade e as relações com a psicopatologia da epilepsia.

\footnotetext{
${ }^{33}$ Minkowska, F. (2007). Van Gogh, sa vie, sa maladie et son oeuvre.Paris: Hamattan. (Originalmente publicado em 1933).

${ }^{34}$ Minkowska, F. (1933/2007). Van Gogh, sa vie, sa maladie et son oeuvre. Préface d'Eugène Minkowski. Paris: L'Harmattan.
} 
Como dito anteriormente, a esquizofrenia é marcada em seu núcleo pela perda do contato vital com a realidade e pela dissociação, onde tudo se fragmenta (Minkowski ${ }^{35}$, 1953/2000). Já no paciente epiléptico, observara Minkowska (1956/1978), surge a viscosidade: nele tudo se acumula, condensa, concentra e se aglutina. É desse modo que descreve suas experiências nas quais une a análise fenômeno-estrutural de Minkowski à vivência por meio do Rorschach em seus estudos genealógicos da epilepsia, do Rorschach e dos Desenhos. Ao estudar as famílias de pacientes epiléticos constatou que tal viscosidade também era observada em seis gerações anteriores e nos outros integrantes que não apresentavam as crises epiléticas.

Estudando a genealogia de pacientes epiléticos, Minkowska (1956/1978) observou que os pacientes que apresentavam características mais sensoriais viviam no concreto, viam o mundo em movimento e em imagens, enquanto aqueles que possuíam características mais racionais preferiam o abstrato, o imóvel e o sólido.

Os estudos do casal Minkowski receberam ainda maior rigor com Helman ${ }^{36}$ (1980) e todo o grupo que a acompanhou e segue nesta escola até hoje (Helman, 1998). De acordo com Zéna Helman a observação individual tem, ela mesma, a sua própria história e afirma: "nós encontramos na prática deste método o espírito humanista de uma corrente centrada sobre a pessoa, sobre o vivido, sobre a expressão" (Helman ${ }^{37}, 1991$, p.147).

O estudo da linguagem dos pacientes psicóticos abre uma via de acesso à compreensão dos fenômenos fundamentais tanto em uma dimensão expressiva como relacional. A expressão é uma relação fundamental, particularmente dinâmica e viva. A expressão exteriorizada, endereçada sempre a alguém, postula, nem que seja virtualmente, um espectador, um interlocutor, susceptível de apreender aquele que se

\footnotetext{
35 Minkowski, E. (2000). La esquizofrenia. México: Fondo de Cultura Económica. (Originalmente publicado em 1927).

${ }^{36}$ Helman, Z. (1980). Structure et évolution dans le courant de la psychopathologie structurale. Psychopathologie Structurale, 3.

37 Helman, Z. (1991). A evolução do Rorschach no contexto da psicopatologia fenomenológicaestrutural. Temas, São Paulo, 40/41,146-163.
} 
expressa. A expressão revela a coexistência, a troca e a interação ou a ausência delas (Ternoy $\left.{ }^{38}, 1999\right)$.

\subsection{Michel Henry (1922-2002)}

Michel Henry nasceu no dia 10 de janeiro de 1922 em Haïphong, na Indochina. Seu pai foi comandante da Marinha e morre em um acidente de carro quando Michel Henry tinha dez dias de vida. Sua mãe, pianista, ficou na Indochina com seus dois filhos $\left(\right.$ Audi $^{39}$, 2006). Renunciou à carreira para se dedicar à educação dos filhos. Da infância, Henry guarda na memória os jogos em um grande jardim e as longas viagens no mar quando voltavam das férias de verão na França. Da vida no Oriente, traz o amor pelas antigas civilizações da Ásia, o estilo de seus monumentos e suas estátuas (Wondracek $\left.{ }^{40}, 2010\right)$.

A família mudou-se para a França em 1929. Após um período de aclimatação em Anjou e Lille, residência do avô materno, que era maestro e diretor de um conservatório de música, a viúva Henry e seus dois filhos se instalam em Paris. Michel Henry estuda no Liceu Henri IV, e suas qualidades intelectuais chamam a atenção do professor de literatura francesa, Jean Guéhenno. Nos anos finais, a filosofia ganha sua paixão e a escolha para a graduação. Nas aulas preparatórias para a universidade, marca-o o curso com o filósofo Jean Hyppolite, que se torna seu co-orientador na graduação, ao lado de Jean Wahl. Estuda filosofia com Paul Ricoeur, que mais tarde esteve na sua banca de doutoramento. Durante o inverno de 1942-1943, escreve sua monografia de conclusão de curso sobre Espinosa, intitulada A felicidade de Espinosa. O diretor Jean Grenier quer publicá-la pela Editora Gallimard, mas as restrições de papel e a censura nazista impossibilitam-no por alguns anos (Wondracek, 2010).

\footnotetext{
${ }^{38}$ Rorschach, psicosis y alucinaciones: enfoque fenomeno-estructural. Psicodiagnosticar , v. IX, Año XI, 34-46.

${ }^{39}$ Audi, P. (2006). Michel Henry. Une trajectoire philosophique. Paris: Société d'édition Les Belles Lettres.

${ }^{40}$ Wondracek, K. H. K. (2010a). Ser nascido na Vida: a fenomenologia da Vida de Michel Henry e sua contribuição para a clínica. Tese de doutorado. São Leopoldo: Escola Superior de Teologia. Disponível em: http://tede.est.edu.br/tede/tde_busca/arquivo.php?codArquivo=245
} 
Em 1943, segue seu irmão à Inglaterra e ingressa na Resistência, numa divisão constituída por intelectuais. Seu codinome foi Kant, pois sempre carregava consigo o livro Crítica da Razão Pura. Atuou na região de Lyon, controlada por Klaus Barbie, de sinistra memória. A vida na clandestinidade e a necessidade de ocultar-se marcarão profundamente seu pensamento filosófico (Wondracek, 2010).

Entre 1944 e 1946, procede à revisão de Metafísica e Moral. A guerra impede a possibilidade de aspirar a seguir carreira na filosofia e, em 1945, Michel Henry passa a considerá-la apenas para reflexão pessoal, enquanto ganha a vida ministrando aulas. Lê Sein und Zeit de Heidegger, ainda não traduzido ao francês, e pouco depois visita o filósofo alemão em sua reclusão no chalé de Todtnauberg, durante estadia na Floresta Negra com amigos (Wondracek, 2010). A longa entrevista o fascina e expressou certo descontentamento com a ênfase fenomenológica de Heidegger na exterioridade, primícias de suas críticas posteriores ao rumo tomado pelo pensamento ocidental (Wondracek, 2010).

Casou-se com Anne Henry em 1958. Até 1960, as atribuições da Fundação Thiers impedem-no de se dedicar com mais afinco a suas próprias pesquisas. A partir de 1960, torna-se professor titular da Cadeira de Filosofia da Universidade de Paul Valéry em Montpellier, preferida à Sorbonne por ser distante da agitação cosmopolita com seus modismos filosóficos e de ideologias dominantes. Isso lhe dá condições de aprofundar suas próprias reflexões e escrever textos significativos que as explanem. Mantém-se nesse posto até sua aposentadoria, em 1982, apesar dos convites quase anuais de mudar-se para a Sorbonne. Lá, torna-se professor convidado, bem como da École Normale Supérieure de Paris, da Universidade Católica de Louvain, da Universidade de Washington (Seattle) e da Universidade de Tóquio (Wondracek, 2010).

A relação de Henry com sua história pessoal é resumida de forma emblemática na entrevista concedida a Roland Vaschalde, que também nos dá uma ideia do seu modo de pensar: "A história de um homem, as circunstâncias que o envolvem, é outra coisa que uma espécie de máscara, mais ou menos lisonjeira, que ele mesmo e os outros estão de acordo em colocar sobre o seu rosto - ele que, no fundo, não tem 
rosto algum. Você observa que eu nasci em um país distante. É o que me disseram. Mas este país não é mais longe do que a Índia e a China? Para mim, eu nasci na vida, da qual ninguém ainda encontrou a fonte em algum continente. Eu não conheci meu pai - mas não está nisso a condição de todos os seres vivos? O homem do qual minha mãe falou mais tarde era capitão de longo curso, eu o vejo como um personagem de Conrad ou de Claudel. Na verdade, eu nada sabia dele. Mas eu sabia algo a mais sobre a criança que passou seus primeiro anos ali? Nós vivemos em um eterno presente que nunca nos abandona. O que permanece fora dele está separado de nós por um abismo. E isso porque o tempo é um meio de irrealidade absoluta. Eu partilho da opinião do Mestre Eckhart: “O que se passou ontem está tão longe de mim quanto o que se passou há dez mil anos" (Henry $\left.{ }^{41}, 2007\right)$.

\subsection{A fenomenologia da Vida}

A fenomenologia da Vida foi criada por Michel Henry (1922-2002) e mostra uma amplitude crítica que afetou também as ciências da saúde, especificamente a medicina e a psicoterapia. Em 2001 o Instituto de Patologia e Imunologia Molecular da Universidade do Porto ${ }^{42}$ organizou um evento científico interdisciplinar. Os textos apresentados e publicados nesse evento vão desde os caminhos de Santiago no sentido inverso, o estranho terrível outro, até a ciência e consciência. É neste penúltimo grupo que apresentaram trabalhos Christophe Déjours (Subjetividade, trabalho e ação), João Lobo Antunes (Loucura), Antonio Damásio (How the brain creates the mind), André Green (Qual cultura para o devir) e Michel Henry (Eux en moi: une phénoménologie), entre outros. Florinda Martins trabalhou com Michel Henry por mais de duas décadas e nos conta que foi na medicina da cidade do Porto que Henry expõe as contribuições da fenomenologia da vida ou material para as psicoterapias, tendo tido boa aceitação.

No Japão desenvolve a genealogia da psicanálise ${ }^{43}$, fazendo críticas contundentes à metapsicologia freudiana, mas não à sua terapêutica. Em um de seus romances (O filho do rei), Henry é bastante pessimista quanto a qualquer psicoterapia,

\footnotetext{
${ }^{41}$ Audi, P. (2006). Michel Henry. Une trajectoire philosophique. Paris: Société d'édition Les Belles Lettres.

${ }^{42}$ Amorim. A. et al (2001). Os outros em eu. Porto 2001. Capital Europeia da Cultura. p.242.

${ }^{43}$ Henry, M. (2009). Genealogia da psicanálise - o começo perdido. Tradução e Notas: Rodrigo Vieira Marques; Apresentação: Florinda Martins. Editora UFPR: Curitiba, 2009.
} 
mas na genealogia da psicanálise reformula sua afirmação anterior e afirma que a psicoterapia é possível. Do ponto de vista psicológico, Michel Henry contribui com uma teoria da afetividade que a coloca como central na Vida dos seres humanos. Não há nada anterior ao afeto, pois somos afetos na Vida, afetados por ela desde o nascimento. Todas as manifestações posteriores, sejam comportamentais ou do pensamento, são manifestações afetivas. Há na intersubjetividade o contato entre dois pathos, e o papel do terapeuta é auxiliar o outro a transformar seu sofrer em fruir, em uma relação de copropriedade e na dialética dos afetos, como desenvolve Florinda Martins na coordenação científica do projeto internacional de investigação em rede: o que pode um corpo? - O olhar clínico é um olhar transcendental e se experiencia no coração da realidade humana. Apresentar-se-ão as possibilidades de ter na teoria de Michel Henry novos fundamentos para a psicologia clínica, especificamente a psicoterapia, o acompanhamento terapêutico e a psicopatologia.

O filósofo e romancista Henry faz parte da família de fenomenólogos "sem mundo" (assim como Lévinas, e talvez Derrida), que nós poderíamos opor àqueles fenomenólogos "do mundo" (Heidegger, Mearleau-Ponty). Ele critica os sistemas filosóficos que esquecem o essencial da vida. Henry elaborou uma fenomenologia da Vida que não trai seu modo de manifestação. Ele fica nessa esfera de imanência ${ }^{44}$ onde a vida aparece como o que se sente a si mesmo. Henry procura, entender o eu e os fenômenos do mundo a partir do viver e de seu auto-afeto, impulsionando essa obra densa e rigorosa (Audi, 2006). A Duplicidade do aparecer, a vida como auto revelação dinâmica e patética ${ }^{45}$, o auto afeto como essência da afetividade, o corpo, a ipseidade do sujeito, a relação ao Outro, a imanência, são seus interesses principais.

\footnotetext{
${ }^{44}$ Imanência radical - Propriedade de o aparecer se apresentar a si mesmo, sendo essa a condição de todo seu aparecer atual e ulterior; modo de permanecer em si sem jamais sair de si. "Descrever algo na imanência significa que eu estive a descrever a experiência que tenho daquilo - por exemplo, ao descrever a dúvida, a minha descrição é feita por de dentro da própria dúvida; na sua imanência."(FMt) "Imanência é corporeidade como percepção-recepção (Empfinden) - A revelação de Deus se dá ali."(RK) In: (Wondracek, 2010)

45 Patético: adjetivo que suscita uma emoção intensa, muitas vezes penosa (dor, pena, horror, terror, tristeza) por exemplo: um filme patético, caráter patético, expressão do que é próprio e emocional, fortemente e que vem de Pathos: tom patético excessivo em um discurso ou escrito - Le Micro-Robert Poche Dictionnaire de la langue française, 1998, p.951, Paris, Dictionnaire Robert Inc. Pathos [patos], palavra grega, paixão. Pejorativo. Pesquisa inoportuna dos efeitos de estilos dramáticos; próprio pleno de ênfase e pouco claro - Le petit Larousse Illustré, 2001, p.755, Larousse/HER, Montréal, Québec.
} 
Na fenomenologia da Vida, pathos é o modo como a vida se abraça, na auto afecção, na unidade indivisível e substancial da matéria fenomenológica de alegria e da dor. É a estrutura fundamental da afetividade ou da essência da manifestação (...). Wondracek (2010, p.251) afirma que "O sentimento é pathos $e$ as tonalidades do pathos, as passagens do sofrimento à fruição só no pathos são possíveis. Este parece ser o grande contributo de Michel para a compreensão de nós mesmos, do nosso sofrimento e da sua conversão em fruição da Vida."

Um dos principais biógrafos de Michel Henry, Paul Audi (2006), mostra conteúdos essenciais da fenomenologia da vida proposta por Henry. Nela, o central é a relação aos fenômenos imutáveis (intangible) e absolutos que ele denominou: o indivíduo transcendental ou a ipseidade. O lugar (lieu) é o presente vivo da vida subjetiva absoluta. Para Henry o Real é importante, ele questiona o que é o Real que está, segundo Audi (2006, p.20) em todas as pesquisas fenomenológicas de Henry. Ipseidade do vivo é a grande contribuição de Henry à fenomenologia. O problema da essência do corpo carnal está no coração da obra de Henry.

A vida é em primeiro lugar e antes de tudo "afetividade". Porém, como determinação transcendental, e também como origem de toda doação de ser. Tudo o que se manifesta se o faz na afetividade e por ela. Ela é a materialidade fenomenológica pura de se provar a si mesma e dessa maneira, a possibilidade principal concreta e a essência da subjetividade absoluta.

A filosofia da subjetividade de Michel Henry vê no Gozar e no Sofrer as categorias fundamentais nas quais consiste propriamente a nossa experiência do ser. Michel Henry se preocupou em esclarecer as leis transcendentais que regem a vida subjetiva absoluta e ele dizia que ela é, no seu princípio, toda poderosa e intemporal. Henry reconhecia que a morte ficava para ele "alguma coisa incompreensível" e que na vida "não há lugar para a Morte" e que "de uma maneira ou de outra, de uma forma ou de outra, a vida ganhará sempre” (Audi, 2006, p. 232-233).

A proposta de uma fenomenologia não intencional busca fazer uma inversão da fenomenologia, não mais se dirigir à exterioridade do mundo, mas a si mesmo, ao ser que é afetado na vida e pela vida, somos afetos na vida, afetados a partir de dentro. 
Conceber a fenomenalidade de outro modo é, no mesmo movimento, não apenas obrigar a uma nova maneira de pensar, mas simultaneamente abrir novos campos de investigação afirma Henry ${ }^{46}$ (2006). As investigações de Henry servem como fundamentos para uma clínica assentada nas origens e no fenômeno da afetividade.

"Afastar da realidade dos objetos suas qualidades sensíveis é eliminar, ao mesmo tempo, nossa sensibilidade, o conjunto de nossas impressões, emoções, desejos e paixões, pensamentos, em suma, toda nossa subjetividade, que constitui a substância de nossa vida. É essa vida, portanto, tal como se experimenta em nós em sua fenomenalidade incontestável, essa vida que faz de nós seres vivos, que se vê despojada de toda verdadeira realidade, reduzida a uma aparência" (Henry ${ }^{47}, 2012$, p.15, 2012).

"O sofrimento, por exemplo, expressa o sofrimento; traz em si, em sua própria carne, o desejo invencível de mudar a si mesmo" (Henry, 2012, p.16, 2012)

Henry propõe que a ciência seja julgada pelo critério da Arte. Não é intenção fazer do Ateliê de Desenho de livre expressão um lugar para produção artística, mas possibilitar a expressão da sensibilidade. Para Heny (2012, p.49): “A arte, com efeito, é uma atividade da sensibilidade, a realização de seus poderes, ao passo que, com a eliminação das qualidades sensíveis da natureza, a ciência moderna define seu campo próprio e se define a si mesma por exclusão dessa mesma sensibilidade".

Assim o "mundo real no qual vivem os homens insere-se totalmente nas categorias da estética, e só pode ser compreendido por seu intermédio" (Henry, 2012, p.53). Excluir a sensibilidade na ciência é impossível, afirma Henry. "É do mundo científico apenas que a sensibilidade é eliminada. E é o motivo pelo qual esse mundo é abstrato". Mas a sensibilidade não desaparece, pois o cientista está lá para interpretar os dados. "A sensibilidade é por essência individual, pois a auto afecção constitui,

\footnotetext{
${ }^{46}$ Henry, M. (2006). Fenomenologia não-intencional. Phénoménologie non intencionelle: une tâche por une phénoménologie à venir. Phainomenon (Centro de Filosofia da Universidade de Lisboa), Vol. 13, pp. 165-177. Disponível em: http://www.lusosofia.net/textos/michel_henry_fenomenologia_nao_intencional.pdf ${ }^{47}$ Henry, M. (2012). A Barbárie. São Paulo: É Realizações Editora. (Originalmente publicado em 1987).
} 
como tal, a essência de toda ipseidade possível" (Henry, 2012, p.56). "A arte é a representação da vida" (p.67)

A fenomenologia em Michel Henry caracteriza-se pelo reportar de todos os movimentos da vida subjetiva ao seu solo original: à sua afeção primordial. É pela declinação no afeto que a intencionalidade, a consciência, todas as prestações transcendentais do sujeito são simultaneamente fenômenos vivenciados na dupla dimensão do sofrer / fruir. As implicações da fenomenalidade do afeto nesta dupla dimensão sofrer / fruir interessam, sobremaneira, às ciências da saúde, nomeadamente à psicopatologia e psicoterapia. O essencial da nossa atividade prende-se com a possibilidade fenomenológica da questão da passagem do sofrer ao fruir da vida. É neste contexto que a fenomenologia de Henry entra no Brasil (Faculdades EST / Universidade de São Paulo): atendemos à possibilidade da passagem do poder do sentimento (sofrer o afeto) ao sentimento de poder (fruir do afeto). Como parceiros da nossa investigação temos o grupo "O que pode um corpo?», coordenado por Florinda Martins, do CEFi, que desde os anos 80 trabalha a fenomenologia da Vida, em Henry, na sua articulação direta com a medicina e com o papel do corpo na redefinição da fenomenologia. O nosso ser, mesmo enquanto eu /ego, vivencia-se no corpo: a encarnação é assim o tema que reúne fenomenologia, ciências médicas e fenomenologia da religião. O pathos primordial é o afeto na Vida que se torna paradigma de relação, nomeadamente da relação terapêutica. Assim, temos ainda como parceiros o grupo de fenomenologia francesa contemporânea coordenado por Rolf Kühn, de Freiburg, Alemanha. Na fenomenologia da vida, a melancolia ou os traumas psíquicos são ressignificados antropológica e clinicamente, abrindo novas possibilidades terapêuticas na relação entre fenomenologia e psicoterapias, especialmente na dimensão do originário e do irrepresentável.

A fenomenologia da alteridade chegou a mim em um livro de Florinda Martins, “Recuperar o Humanismo”48, O prefácio, escrito por Michel Henry ${ }^{49}$ (2002, p.9), já traz

\footnotetext{
${ }^{48}$ Martins, F. (2002). Recuperar o Humanismo. Para uma fenomenologia da alteridade em Michel Henry. Cascais: Principia. Conheci este livro no Congresso Luso-Brasileiro de filosofia fenomenológica, na Universidade de Lisboa, Portugal, dezembro de 2007. Foi o primeiro contato com a obra de Michel Henry e Florinda Martins. Nessa ocasião, Florinda Martins estava lá, mas não nos conhecemos. Nesse evento apresentei um trabalho sobre Acompanhamento Terapêutico a partir de Eugène Minkowski, em co-autoria com Kleber Duarte Barretto e Gilberto Safra, bem como ministrei uma conferência dobre a
} 
ideias que vieram de encontro às minhas preocupações em relação à fenomenologia: "A fenomenologia da Vida obriga a repensar toda e qualquer questão essencial, nomeadamente a da experiência do outro." (..) "nunca é do ego que se deve partir; a intersubjetividade não é uma relação entre -ego(s) (...) O que é antes de nós 'antes do nosso Si, do nosso eu e do nosso ego' dá-se em nós, que n'Ele somos com os outros". Para Henry, essa "concepção de alteridade de Florinda Martins 50 avança em uma nova concepção de alteridade, é uma outra fenomenologia".

É a fenomenologia do afeto que interessa a Henry, ele "opera, no método fenomenológico, uma contrarredução que faz a passagem da doação de um horizonte, de uma idealidade vivida, à vivência afetiva, ao transcendental concreto. Assim, a fenomenologia da vida afetiva desvincula-se dos seus tradicionais problemas redução, intencionalidade, doação em pessoa, eu transcendental, espectador transcendental, constituição do eu, síntese de passagem, síntese passiva - para se situar no seio da própria doação, na afeç̧ão de si geradora de relação" Martins (2002, p.14).

É entre o outro e o eu ou entre si(s) que as relações de afeto se tecem (Martins, 2002, p.15). A relação se dá na experiência afetiva do meu corpo, não em horizontes teóricos de projeções. É a vida que originariamente se afeta como singularidade ou, na linguagem fenomenológica, como ipseidade.

Na fenomenologia da Vida de Henry “o que se fenomenaliza é a própria vida: é ela que a si mesma se manifesta, e não uma forma especular de si. Daí o método não prender ao preenchimento de evidências ou a obscuridades que é preciso desvelar, mas com a descrição da gênese das tonalidades afectivas com que a vida se nos presenteia para dela usufruirmos e nela agirmos" (Martins, 2002, p.15).

importância da Empatia na psicoterapia a partir de Edith Stein, no Instituto Superior de Psicologia Aplicada - ISPA, de Lisboa. Três anos depois o Professor Gilberto Safra me apresentou Florinda Martins (por intermédio da Professora Karin Wondracek) e juntos organizamos a primeira conferência dela no Instituto de Psicologia da Universidade de São Paulo em 2010.

49 Henry, M.(2002).Prefácio. In: Martins, Florinda. (2002). Recuperar o Humanismo. Para uma fenomenologia da alteridade em Michel Henry. Cascais: Principia.

${ }^{50}$ Martins, Florinda. (2002). Recuperar o Humanismo. Para uma fenomenologia da alteridade em Michel Henry. Cascais: Principia. 
“As relações intersubjetivas alicerçam-se na fenomenologia da passibilidade da Vida, cujo sofrer-se é disponibilizar-se à relação" e Martins (2002) afirma que é pela afeição de si que a vida se nos doa, propondo o diálogo da Vida com a facticidade se abrindo a um novo diálogo ente a Vida e os fatos.

\subsection{Da fenomenologia à clínica: em busca de uma humanologia}

O que interessa à Humanologia que proponho é ater-se às biografias diferentes, em diálogo entre o universal e a singularidade pessoal em relação com a interdisciplinaridade. Na clínica é isso que ocorre na relação com nossos pacientes, somos semelhantes do ponto de vista universal, mas distintos nos conteúdos.

Em Edith Stein, o método fenomenológico é útil à clínica, pois temos nessa vertente uma concepção antropológica de Homem e da estrutura da pessoa humana (corpo-psique-espírito). Seu estudo sobre a empatia traz um modo de conhecer a vivência alheia, a partir de nossos valores e de nossa corporeidade.

Minkowski valoriza nosso instrumento principal, ou seja, nossa própria personalidade, ao destacar o diagnóstico realizado pelo sentimento ou por compenetração. Tanto ele quanto Stein enfatizam a intuição.

Em Henry encontramos um Homem encarnado, tendo como essência da Vida a afetividade. Esses autores procuram conhecer o humano sem teorias prévias que possam obscurecer o fenômeno estudado, tal como propõe Gilberto Safra na trilogia da estética, ética e o sagrado, indo em direção ao idioma pessoal de cada pessoa, à sua semântica pessoal. Esse pré-conhecimento permite uma compreensão anterior à atividade mental ou representacional.

O que me chama atenção em todos esses autores são o rigor e a densidade de seus trabalhos, a importância do pensamento, mas antes de tudo dos afetos ou da afetividade e a aceitação da existência do mistério humano.

Assim, nos enveredaremos a algumas considerações na importância do estudo de caso, da subjetividade revelada pela intersubjetividade. Maiores desenvolvimentos das perspectivas de cada autor serão apresentados no decorrer das próprias discussões, e que não foram apresentadas anteriormente. Ir em direção à essência de 
cada pessoa é um interesse que dá suporte e base a toda clínica que descreverei a seguir. Em psicologia clínica encontramos teorias psicodinâmicas, porém, ao aceitarmos uma proximidade interdisciplinar com a fenomenologia, teremos que optar por outro caminho, o ateórico. Alberto Caeiro ${ }^{51}$ (1888-1935) ilumina ainda mais essa escolha: "O essencial é saber ver, Saber ver sem estar a pensar, Saber ver quando se vê, E nem pensar quando se vê, Nem ver quando se pensa. Mas isso (tristes de nós que trazemos a alma vestida!), Isso exige um estudo profundo, Uma aprendizagem de desaprender".

É nessa "aprendizagem de desaprender" que pude me abrir para o desconhecido da fenomenologia para aproximá-la da clínica como eu a vivo.

\section{Capítulo 4: Estudo de Caso}

Podemos abordar os fenômenos intersubjetivos que ocorrem nas relações humanas por meio do método fenomenológico. Do ponto de vista epistemológico, de acordo com Safra ${ }^{52}$ (2005), o modelo usado neste projeto de psicologia clínica é o modelo de investigação 'sujeito-sujeito', no qual o rigor é a interação com a subjetividade dos pacientes, explicitando como os fenômenos operam. O foco de interesse neste modelo é a narrativa, a descrição e a compreensão do fenômeno. 0 rigor não é o da explicação ou do controle de variáveis como no modelo de investigação 'sujeito-objeto', mas sim o da compreensão que revela e desvela os sentidos das experiências. Na pesquisa 'sujeito-sujeito' termos como qualitativo e quantitativo não têm sentido, esta perspectiva metodológica tem a sua própria linguagem e semântica (Safra, 2005).

A compreensão intuitiva e profunda de casos particulares foi citada por Jaspers $^{53}$ (1911/1979) em sua obra sobre psicopatologia. Jaspers afirma que "muitas

\footnotetext{
${ }^{51}$ Pessoa, A. (1980). Poemas completos de Alberto Caeiro. Fiç̧ões do Interlúdio 1. Rio de Janeiro: Editora Nova Fronteira. p.64.

52 Safra G (2005). Método de pesquisa: do projeto à elaboração do texto final. As metodologias contemporâneas e suas bases epistemológicas, como foco na pesquisa em Psicologia e Psicanálise. Aula ministrada no curso de pós-graduação em psicologia Clínica da USP em 16 de março de 2005. DVD Vídeo. Edições Sobornost.

${ }^{53}$ Jaspers, K. (1979). Psicopatologia geral. Psicologia Compreensiva, explicativa e fenomenologia. Rio de Janeiro: Atheneu. 2a ed. (Originalmente publicado em 1911)
} 
vezes o aprofundamento penetrante num caso particular ensina fenomenologicamente o que é geral para inúmeros casos. O que se apreendeu de uma vez encontra-se na maioria das vezes logo a seguir. Na fenomenologia importa menos se acumularem casos sem fim do que a visão interna, o mais possível completa, de casos particulares" (p.72).

“O importante na fenomenologia é, portanto, exercer a visão pregnante do que é vivido diretamente pelo doente a fim de poder reconhecer o que há de idêntico dentro da multiplicidade. É necessário assimilar inteiramente, por meio de exemplos concretos, um rico material fenomenológico. Ele nos confere critério e orientação em novos casos" (Jaspers, 1979, p.73).

Assim, o que importa na fenomenologia é menos o estudo de inumeráveis casos, mas a compreensão intuitiva e profunda de alguns casos particulares (Barthélémy $\left.{ }^{54}, 2006\right)$. A atitude fenomenológica fornece um valor especial ao caso típico. A atitude ou o ato fenomenológico ultrapassa o plano de observação e tende à visão das características essenciais dos fenômenos que compõem a vida em sua essência. De acordo com Helman (1991), neste método um caso é suficiente para elucidar o modo de ser do outro. Assim, a fenomenologia nos convida a nos demorarmos sobre os fenômenos a fim de precisar seus caracteres fundamentais.

Minkowski (1923/1970) valoriza o contato direto com o doente como foco de suas investigações. O contato pessoal é indispensável em sua perspectiva humanista, porque é ele que revela a presença da essência do outro. Como exemplo cita o caso de um paciente alienado do convívio social como sendo excluído da comunidade na qual vive. Ele detecta naquele paciente com esquizofrenia melancólica o desacordo de duas melodias humanas - a do terapeuta e a do paciente - que se confrontam a maior parte do tempo e apresentam a estrutura do tempo vivido em cada um deles. No paciente, 0 tempo se fragmenta e ele perde a ressonância no contato com o outro, sua vida perde o colorido. O devir do paciente está barrado por suas ideias delirantes. O passado o imobiliza pelas ideias de culpa, o tempo presente aparece sob a forma de ideias

${ }^{54}$ Barthélémy, J. M. (2006). Importance et extension de l'approche qualitative dans la méthode phénoméno-structurale en psychopathologie. Bull. Soc. Sci. Méd. 2, 249-264. 
indignas de ruína. Em nós, terapeutas, o devir está em aberto. Para ele o paciente ou o outro é compreendido como um ser diferente e semelhante e não um doente.

Do ponto de vista clínico, como visto, me volto aos estudos de caso em psicopatologia. Anteriormente descrevi notas bibliográficas de Edith Stein, Eugène Minkowski e Michel Henry, e algumas considerações sobre o que representa o método fenomenológico para cada um.

Em seguida, apresentarei as articulações desses métodos fenomenológicos a três modalidades de atendimento clínico: atendimento clínico em grupo (Ateliê de desenho de livre expressão), acompanhamento terapêutico e a psicoterapia. Por fim, apresento as conclusões, que versam sobre uma compreensão teórica da clínica e da psicopatologia baseada na fenomenologia desses autores.

\section{Capitulo 5: 0 atendimento clínico em grupo e os desenhos}

A expressão por meio do traçado do desenho é uma das primeiras descobertas da infância. Através dos desenhos, as crianças se apropriam da possibilidade de lidar com seu mundo interno e externo. O ambiente é responsável por muito da compreensão do traçado em significados, em sentidos e em associações, e essa mudança é decisiva para o desenvolvimento humano.

Segundo Pablo Picasso ${ }^{55}$ (1937), o desenho não é um jogo. Ele refere que é muito misterioso o fato de que o traço possa representar um ser vivo. Não somente sua imagem, mas, sobretudo, aquilo que ele realmente é. Mas, além de revelar ao outro os aspectos internos de quem desenha, ele apresenta ao próprio autor muitas respostas e potenciais de desenvolvimento. Assim, muitas instituições que oferecem tratamento psiquiátrico e psicológico têm adotado a expressão por meio do desenho de uma maneira terapêutica (Santoantonio \& Antúnez ${ }^{56}, 2002$ ).

\footnotetext{
${ }^{55}$ Picasso, P. (1937-1945). Anos de guerra [Exposição]. São Paulo: Museu de Arte de São Paulo Assis Chateaubriand; 21/09 a 15/11 - 1999.

${ }^{56}$ Santoantonio, J., \& Antúnez, A. E. A. (2002). Atelier de pintura de livre expressão em hospital dia psiquiátrico [Versão Eletrônica]. Inter-Ação.com. Recuperado em 10 maio 2008, de http://www.ciec.org.br/Artigos/Revista_1/jacqueline.pdf
} 
A pintura e o desenho como possibilidades de se expressar é uma ação humana mais complexa que um simples traço sem importância. O pintor holandês Van Gogh (1853-1890) traz questionamentos importantes para refletirmos nossa investigação. Ele responde de modo profundo à importância de desenhar a partir de duas indagações: "O que é desenhar? Como o conseguimos?" E responde: "É a ação de abrir-se um caminho através de um muro de ferro invisível, que parece encontrar-se entre o que sentimos e o que podemos. Como atravessar este muro, já que de nada serve golpeá-lo com força? Devemos minar este muro e atravessá-lo à base de lima e, no meu entender, lentamente e com paciência. E é assim que podemos continuar assíduos neste trabalho sem nos distrairmos, a menos que não possamos e não arranjemos nossas vidas segundo nossos princípios. E isto vale tanto para as coisas artísticas quanto para as outras" (Van Gogh $\left.{ }^{57}, 2010\right)$.

A meta com este estudo é utilizar os desenhos para auxiliar pessoas com grave sofrimento psíquico, ao compartilhar o que foi criado, dando reconhecimento aos seus gestos motores e verbais, no sentido dado por Ternoy ${ }^{58}$ (1999), em que ser é fazer e dar significado ao que foi realizado.

Françoise Minkowska não se dirigia apenas ao Rorschach, mas também à análise dos desenhos de crianças epiléticas, aos estudos da obra do pintor holandês Van Gogh na sua sensorialidade em comparação com a do pintor francês Seurat e sua racionalidade, como modos distintos de ser.

Considerando outra vertente de pensamento que influencia a análise fenômenoestrutural na sua concepção atual, a obra de Prinzhorn ${ }^{59}$ (1922/1984) dá importância às produções dos pacientes, desenhos e pinturas, campo do imaginário e da expressão como fonte de estudo (Helman, 1998).

\footnotetext{
${ }^{57}$ Van Gogh, V. (2010). Cartas a Théo. Tradução de Pierre Ruprecht. Porto Alegre : L\&PM Pocket. 416 p.

58 Ternoy, M. (1999). Rorschach, psicosis y alucinaciones: enfoque fenomeno-estructural. Psicodiagnosticar , v. IX, Año XI, 34-46.

59 Prinzhorn H (1995). Artistry of the Mentally ILL. In MacGregor JM (1922). Princeon University Press, pp.161-184.
} 
O Ateliê de Pintura de Livre Expressão (Santoantonio \& Antúnez, 2010) é baseado na observação participante e ativa como procedimento terapêutico no tratamento de pacientes com transtornos psiquiátricos graves. Tal técnica foi criada e desenvolvida em sua tese de doutorado por Ternoy (1997), sob orientação de Zéna Helman. Não se trata de oferecer ao paciente uma simples distração, ocupação ou mesmo a produção de arte como meio terapêutico com um objetivo artístico ou catártico. O intuito não é que o paciente produza uma grande obra, mas possibilitar a expressão, compreendida por Ternoy como ato e movimento criativo.

O método fenômeno-estrutural permite uma aproximação distinta e peculiar ao sofrimento vivido, possibilitando ações terapêuticas próximas aos fenômenos tal como aparecem em cada paciente. É possível observar na livre expressão: os gestos, as necessidades, as dificuldades, as evoluções e os interesses, as ressonâncias, a empatia ou a ausência dela, os mecanismos essenciais de ligação e ruptura na linguagem verbal e nos desenhos. As intervenções visam aproximar-se do que é próprio de cada indivíduo por meio da espera atenta e silenciosa até que um diálogo se inicie.

O método se apoia na análise do fenômeno buscando precisar suas características fundamentais. A importância de uma reflexão fenomenológica no campo da expressão possibilita entrar em contato com o outro e então compreender sua visão de mundo. Ternoy ${ }^{60}(1997)$ refere que o estudo da linguagem dos pacientes psicóticos abre uma via de acesso à compreensão dos fenômenos fundamentais tanto em uma dimensão expressiva como relacional. A expressão é uma relação fundamental, particularmente dinâmica e viva. A expressão exteriorizada é endereçada sempre a alguém e postula, nem que seja virtualmente, um espectador, um interlocutor, susceptível de apreender aquele que se expressa. Ela revela a coexistência, a troca e a interação ou a ausência disso.

Dessa forma, a expressão no Ateliê não se reduz à coisa realizada, mas à forma de expressão de quem cria. Para tanto o conteúdo da representação é tão importante como o próprio ato criativo. A expressão é compreendida em seu movimento

\footnotetext{
60 Ternoy,M.(1997). Uma característica específica da visão em imagens no alucinado: o detalhismo. I Congrès de la Société Internationale de Psychopathologie Phénoméno-structurale. I Congresso da Sociedade Brasileira de Rorschach e Outros Métodos Projetivos. Ribeirão Preto: ASBRo, p.192-205.
} 
constitutivo e dinâmico e é através da criação que a pessoa existe, se realiza e pode vir a ser $\left(\right.$ Ternoy $\left.^{61}, 1987\right)$.Ao analisar pinturas a partir da fenomenologia, não se trata de buscar possibilidades de associação entre produção psicopatológica e inspirações ou criações artísticas ou mesmo de retornar a questões acerca das ligações entre loucura e genialidade. Cuida-se para não se realizar análises psicopatológicas reducionistas das obras de artes, pois elas têm um caminho detentor de ensinamentos insubstituíveis graças ao poder expressivo do criador. Ternoy comenta que é certo que a loucura não cria o artista, mas o encontro de ambos, loucura e artista, é possível e não poderia ser concebido sem marcas (Ternoy, 1999).

A técnica no Ateliê de Desenho: o material colocado à disposição é composto por lápis preto (2B, 4B e 6B), lápis colorido, de cera, aquarela e carvão. Os desenhos são feitos em papel Canson de 216 × 316 mm. Esses elementos foram escolhidos por serem considerados adequados para a confeç̧ão rápida de produções gráficas.

A sessão: Momento 1 - Cada sessão é composta por dois momentos: o tempo de realização das produções e o tempo de discussão, em um movimento que se inicia no ato de transformar uma folha em branco em uma folha habitada pelo traço, pela imagem que revela a singularidade. A folha representa o espaço vazio que recebe as marcas das imagens da pessoa. O ritmo do trabalho proporciona o aparecimento do gesto, do desenho, em momento de silêncio e concentração. O tempo para desenhar pode durar de 30 a 45 minutos e mesmo os terapeutas fazem seu desenho. Isso é importante, pois pode servir de estímulo e modelo para uma participação ativa de cada participante do grupo. A expressão pessoal é totalmente livre sobre o espaço da folha. Caso perguntem sobre a quantidade de desenhos a fazer, até dois é o indicado. Quando todos terminam, os desenhos são afixados em um mural de cortiça e o grupo posiciona-se num semicírculo frente aos desenhos como espectadores frente às suas obras. A pessoa pode aceitar ou não afixar sua produção. Quem termina rapidamente espera em silêncio quem está ainda produzindo e criando. Cada pessoa pode desenhar o que desejar e decidirá o destino da sua criação, ou seja, poderá expor ou não no quadro para que os outros vejam, poderá levá-lo para casa, dar a alguém, ou aos

\footnotetext{
${ }^{61}$ Ternoy M. (1987). L'espace pictural de groupe. Rorschach et psychopathologie phénoménostructurale. Expression et psychopathologie. In Colloque Octobre. France: Recueil no. 3; pp.12-20.
} 
terapeutas para que arquivem em uma pasta com seu nome. Recomenda-se que ninguém interfira na folha de outro participante sem seu consentimento.

Momento 2 - O coordenador do grupo inicia o segundo momento, o período da verbalização, e fala sobre o seu desenho e o que sentiu e/ou pensou sobre o mesmo e sobre os outros. Os participantes podem fazer perguntas e em seguida abre-se para a expressão do próximo voluntário. Pode-se fazer qualquer comentário ou mesmo optar por ficar em silêncio. A verbalização é registrada pelo coterapeuta e/ou por equipamento de gravação. As intervenções do terapeuta visam facilitar a expressão de sentimentos e pensamentos, de modo que os participantes possam ir mais além das suas formulações objetivando a ampliação dos recursos expressivos.

No momento da discussão a participação também é livre e cada um pode tomar a palavra exprimindo-se dentro de suas possibilidades. Esses comentários podem variar de algumas palavras a explicações mais longas. As intervenções do terapeuta não visam interpretações, mas buscam ampliar as reflexões e impressões do que motivou suas produções. De acordo com Ternoy ${ }^{62}$ (1987), estamos diante do campo da metáfora mais do que da interpretação: "as pessoas reencontram nos desenhos o reflexo do vivido e, a partir de suas descrições, deslizam sobre a evocação de sua própria história".

Os desenhos são observados a partir da verbalização de seu criador e de uma análise fenomenológica-estrutural dos mesmos (Minkowska ${ }^{63}, 1956$; Helman ${ }^{64}, 1959$,

62 Ternoy M. (1987). L'espace pictural de groupe. Rorschach et psychopathologie phénoménostructurale. Expression et psychopathologie. In Colloque Octobre. France: Recueil no. 3; pp.12-20.

\footnotetext{
${ }^{63}$ Minkowska, F. (1978). Le Rorschach. A la recherche du monde des formes. France: Desclée de Brouwer. (Originalmente publicado em 1956).

${ }^{64}$ Helman Z. (1959). La poussée sensori-motrice. Bruxelles: Charles Dessart; 1971.

Helman Z. (1991). A evolução do Rorschach no contexto da psicopatologia fenomenológica-estrutural. Temas, São Paulo, 40/41:146-163.

Helman Z. (1997). Psicopatologia fenômeno-estrutural e método de Rorschach: a evolução de uma corrente, seus desenvolvimentos atuais. Livro do I Congresso da sociedade Brasileira de Rorschach e outros Métodos Projetivos e I Congrès de La Société Internationale de Psychopathologie PhénoménoStructurale. Ribeirão Preto: USP. Orgs, Jacquemin A et al. pp. 279-290.
} 
1991, 1997), que se constitui no modo como utiliza o espaço, o tempo da produção, os mecanismos de ligação, os mecanismos de corte, as cores e as temáticas.

O Ateliê de Pintura de Livre Expressão é uma modalidade de atendimento em grupo que utiliza o desenho como expressão, compreendido em seu movimento constitutivo e dinâmico. A técnica busca favorecer o ato criativo compartilhado em momentos de silêncio e concentração e transita rumo à verbalização e o compartilhar das experiências vividas. A Análise fenômeno-estrutural investiga os fenômenos essenciais que animam ou não a estrutura da personalidade, a saber, quais os mecanismos que predominam: de ligação ou de corte.

A observação de casos segundo a psicopatologia fenômeno-estrutural acompanha as pesquisas nesse método. Um caso é ao mesmo tempo fonte de inspiração e experimentação das noções, de modo que a observação tem nesta corrente um lugar primordial. A partir dos casos individuais, são estudados os problemas mais gerais. A psicopatologia fenômeno-estrutural encontra nos desenhos e, principalmente no Rorschach, um método rico que recorre à expressão e à estrutura, que pode relacionar o modo de visão, a linguagem e o comportamento (Helman, 1997).

De acordo com Barthélémy ${ }^{65}$ (1997), a análise fenômeno-estrutural encontra seu lugar entre a psiquiatria e a psicanálise: ela não se atém ao conteúdo, mas dirigese à forma, apreendida em sua mobilidade e dinamismo vivo; não usa o conceito de inconsciente, mas encontra no consciente as forças criativas que se afirmam por elas mesmas; e não recorre a interpretações com auxílio de simbolizações, mas recorre à vida e à riqueza e força expressiva da linguagem.

65 Barthélémy, J.M. (1997). A análise da linguagem no Rorschach segundo o método fenômenoestrutural. Anais - I Congresso da Sociedade Brasileira de Rorschach e outros Métodos Projetivos e I Congrès de la Société Internationale de Psychopathologie Phénoméno-structurale. Ribeirão Preto, 99104. (trabalho completo) 
Os desenhos são criações fundamentais e integrantes da evolução da estrutura da personalidade. Na maioria das pessoas eles são deixados de lado após a infância. Nesta etapa, as crianças comunicam muito de si nos desenhos, nas cenas, no brincar.

Quando propomos aos pacientes adultos desenhar, não raras vezes encontramos respostas como: 'desenhar é coisa de criança', 'eu não sei desenhar', 'desenhar não leva a nada', 'o que eu poderia fazer?'. Ao serem estimulados a desenhar o que quiserem, os pacientes logo lançam seu gesto e mais que nós nos surpreendermos, eles se surpreendem! O que importa é transformar uma realidade, a partir de seu gesto.

Nos desenhos realizados pelos pacientes no Ateliê observa-se que cada pessoa se depara com uma faceta de sua própria liberdade, frente à qual tem que decidir em participar ou não do grupo, em desenhar ou não, optar pelo que lhe interessa expressar por meio de imagens, reconstruir uma realidade que lhe é oferecida - a da folha em branco - a partir de seu gesto e de sua ação.

No segundo momento - do diálogo - o paciente poderá mais uma vez optar por comentar algo a respeito da imagem que apresentou ao grupo, o que pensou, o que sentiu, o que o motivou ou qualquer outra comunicação, mesmo a do silêncio. Liberdade e Expressão são dois conceitos fundamentais que acompanham cada participante e são respeitados como criação e contribuição à atividade. O que importa é poder fazer uso desta liberdade, por mais danificada que esteja ou se apresente, favorecendo a expressão por meio da imagem e da verbalização. $O$ ato terapêutico está no acolhimento oferecido na atividade, desde o nascimento da imagem e da fala que a acompanha, bem como de seu criador, com respeito e ética.

Tal diálogo coordenado pelos terapeutas pretende oferecer um reconhecimento do gesto humano em imagem, em comunicação verbal, em presença na relação. Observamos que os pacientes revelam a partir da imagem e da fala muito do seu sofrimento, de suas angústias, de seus interesses atuais e daqueles revividos naquele momento de encontro. 
Vivemos em um mundo onde há uma excessiva nomeação do sofrimento humano. Em nosso trabalho em grupo busca-se não classificar os sofrimentos. Encontrei no conceito da filosofia russa de Sobórnost (Safra, 2004) uma compreensão próxima de nossa vivência e manejo clínico das situações que se apresentam. O uso de tal conceito na experiência clínica se aparenta a um modo de clinicar onde os fenômenos que aparecem na interlocução não são codificados ou classificados.

A concepção de Sobórnost é ontológica e procura esclarecer as condições fundamentais para o 'acontecer humano'. É uma palavra russa que não se refere à concepção de indivíduo isolado dos demais, ao contrário, assinala que cada ser humano é a singularização da vida de muitos, de seus ancestrais, sendo o pressentimento daqueles que virão (Safra, 2004).

O Outro implica o contemporâneo, os ascendentes, os descendentes, a coisa, a natureza, o mistério. Diferente do 'outro' sem a presença do vértice transcendente. Safra $(2004$, p.44) refere que "ao estarmos frente a alguém, estamos frente à singularização dos ancestrais e àquelas questões do destino humano, que naquele grupo humano, do ponto de vista transgeracional, se põem em devir em direção ao que ainda não é (...) O que nos demanda uma questão ética e epistemológica assentada no paradoxo. Somente o paradoxo contempla a condição humana como ser no mundo e sempre para além dele. Ao ouvirmos alguém formular as questões do seu destino, estamos ouvindo o sofrimento de um e de todos".

Conversar sobre o devir do ser humano por meio dos acontecimentos é para Safra (2004, p.45) "uma relação ontológica, na qual a cultura possibilita o diálogo entre gerações sobre as questões do destino humano. Este diálogo é realizado por meio da linguagem, dos artefatos culturais e das cerimônias transmitidas através das gerações". No 'Ateliê de Pintura de Livre Expressão' há um momento em que a comunicação é privilegiada por meio da linguagem verbal que, sendo "compreendida por meio do conceito de Sobórnost, é fluxo histórico, presença do passado, do presente e do futuro, e que permite que o dizer seja gesto humano, ação transgeracional geradora de possibilidades de existência. Linguagem que se apresenta 
ao homem como poesia, que o visita e que o gera: linguagem revel-ação" (Safra, 2004, p.46).

Como perspectiva ética, o desenho assinala um lugar em que, ao se estar frente ao outro, frente aos desenhos e da fala, estamos diante da revelação e do não-saber como condição ética. Quando posicionado no não-saber, a revelação da singularidade do Outro pode aparecer e encontrar moradia no ethos humano (Safra, 2004).

O conceito de Sobórnost aborda um evento que é pré-subjetivo e pré-reflexivo, como a compreensão afetiva. Nessa clínica, o terapeuta está presente frente a seu paciente não só como um outro subjetivo, mas "como os ancestrais, como os descendentes, como a humanidade, como representante da cultura, como aquele que sustenta a criatividade, como o incognoscível". O terapeuta assim posicionado é simultaneamente o devir do si mesmo do paciente e o Outro (Safra,2004, p.50).

Esse trabalho clínico nos remete ao comunitário, ao trabalho terapêutico com pessoas em grupo e ao mesmo tempo individualmente. Focalizamos a memória do originário a partir do desvelamento dos fundamentos da condição humana.

Compreende-se o ser humano na dimensão ontológica da abertura. “Ontologicamente, por sermos entes abertos ao ser e ao sentido, temos a possibilidade de alcançar o sentido, quanto de ser jogados no não-sentido" (Safra, 2006, p.29). Nesse sentido o registro ontológico possibilita compreender as vicissitudes decorrentes do modo como o destino humano atinge o Outro e é uma das bases da empatia e da compreensão mútua, favorecendo um posicionamento em comunidade de destino ${ }^{66}$ com nossos pacientes. Safra se refere à importância de compreender o amor não só como um sentimento, mas como lugar e uma posição.

Em relação à experiência com artes, Safra (2006, p.43) comenta que “(...) um mundo é instaurado quando uma música é tocada (que é um tipo de símbolo apresentativo). O símbolo apresentativo propicia uma experiência. Dizer que uma música representa uma emoção ou afirmar que é fruto de um determinado acontecimento histórico ou biográfico é perder a essência da música. Isso é verdade

\footnotetext{
${ }^{66}$ Safra, G.(2004). A po-ética na clínica contemporânea. Aparecida: Edições Sobornost.
} 
também para outras artes, como dança e pintura. São fenômenos que apresentam um mundo e possibilitam uma experiência".

Nessa vertente, a intuição e a empatia não são consideradas como funções mentais, mas corporais: intuímos e "empatizamos" através de nossa sensibilidade (Safra, 2006). O autor refere que “(...) o analista intui o que se passa, não por telepatia, mas pelo fato de seu corpo estar sendo continuamente afetado pela forma de ser do paciente" (Safra, 2006, p.48).

Assim, reúno duas perspectivas clínicas, o método fenômeno-estrutural e a concepção comunitária em Sobórnost. O primeiro, ao compartilhar o que foi criado, reconhecendo gestos motores e verbais que possibilitam a expressão e a análise dos fenômenos fundamentais para compreender a visão do mundo do paciente, na dimensão expressiva e relacional na qual se dirige à forma em sua movimentação e dinamismo vivo. A segunda, que compreende a linguagem como fluxo histórico e que revela o sofrimento dele, paciente, e também da comunidade que o acompanha.

\subsection{Um exemplo de um encontro no Ateliê de Pintura de Livre Expressão}

Descreverei a seguir a vivência ${ }^{67}$ em um ateliê realizado no contexto de um Centro de Atenção Psicossocial - CAPS II , no qual participaram seis pacientes ${ }^{68}$ : cinco $^{\circ}$ profissionais em especialização; uma residente em psiquiatria, duas terapeutas ocupacionais, dois psicólogos ${ }^{69}$; e duas profissionais da equipe fixa: uma psicóloga que coordena o grupo (terapeuta) e uma terapeuta ocupacional (coterapeuta). Procurarei mostrar os acontecimentos tal como foram vivenciados neste grupo; Após essa exposição, apresentarei um estudo de caso $^{70}$ dentro de um outro ateliê, mostrando como é possível acompanhar de perto uma pessoa mesmo que inserida em um grupo. Serão trazidos os aportes de Michel Henry em relação à $\operatorname{Arte}^{71}$.

\footnotetext{
${ }^{67}$ Parte desta sessão foi publicada em http://www.ciec.org.br/Artigos/Revista_5/andres.pdf

${ }^{68}$ Os nomes dos pacientes foram modificados no texto.

${ }^{69}$ Os profissionais em especialização terão seus nomes fictícios seguidos do símbolo $\alpha$.

70 Página 59.

${ }^{71}$ Página 79.
} 
O primeiro momento do grupo é destinado à confecção dos desenhos. Na maior parte do tempo desenhamos em silêncio. Alguns comentários vão aparecendo. llustraremos uma parte da conversa com Celso, paciente que sempre participava da atividade com entusiasmo.

Enquanto desenhávamos ele comentava que naquele dia faria algo muito colorido, pois sempre desenhava em preto e branco por ter muitas dificuldades com as cores. O terapeuta comentou que de fato muitas vezes é difícil lidar com as cores, mas o que seria do mundo sem elas? O comentário foi motivado pela percepção de que Celso demonstrava ao longo de seu acompanhamento uma grande dificuldade em lidar com seus afetos. Conta que sempre acordava antes que os parentes por não se sentir bem em conviver com eles. Achava que não tinha sintonia com eles. Naquele dia, um de seus parentes acordou cedo e falou com ele, o que o deixou muito deprimido. Comentamos sobre o fato de vivermos em um mesmo mundo e, ao mesmo tempo, termos mundos tão diferentes dentro de nós, e falamos sobre afinidades e diferenças.

Aos poucos cada participante desenhava e, ao finalizar, colocava suas produções gráficas em um quadro de cortiça. Os pacientes retornavam ao seu lugar aguardando o momento da verbalização, do diálogo sobre os desenhos produzidos de modo livre. Descreverei em detalhes os desenhos dos pacientes e brevemente os desenhos dos profissionais para que o leitor possa compreender os comentários no momento da verbalização. Quando todos já tinham colocado seus desenhos no quadro, verificamos o seguinte:

Celso desenhou na posição horizontal da folha três objetos nomeando-os ao lado: Comprimido (desenhado com a cor verde-claro), Cápsula (roxo com vermelho) e Drágea (marrom). Maria desenhou na folha em posição vertical um rosto azul que está chorando, ligado por uma seta a um relógio verde com a seguinte sequência de números no mostrador: $12,1,2,3,8,7,6,7,8,9,10,11$ e 12 . Uma seta menor ligava o relógio a outro rosto vermelho que está sorrindo.

Beatriz faz uma moldura com a régua na folha, em posição horizontal, e dentro desenhou uma paisagem. No céu que coloriu levemente com uma mistura de amarelo, vermelho e laranja há um sol representado por um círculo amarelo sem raios. Nuvens 
brancas, um avião, gaivotas pretas e um objeto voador não identificado (óvni) pequeno em cor roxa. No meio da folha, três montanhas desenhadas em dois tons de verde, mesma cor do chão, com uma pequena árvore marrom sem folhas que parece seca. Abaixo e à direita, dando a impressão de ser o primeiro plano, uma grande árvore marrom com folhas verdes que parecem estar brotando. Na árvore, um pequeno beijaflor verde, detalhe por onde começa a descrever seu desenho no momento da verbalização. O chão é pintado em dois tons de marrom. Os traços são leves assim como as cores.

Cristina desenhou com a folha na posição horizontal um jogo da velha. 0 jogo 'deu velha' (sic), ou seja, ninguém ganhou. É a primeira vez que utiliza o giz de cera. As cores são fortes: riscos laranja e símbolos cor de vinho.

Luiz, com o papel na posição horizontal, desenhou várias folhas de diferentes formatos e tonalidades de cor verde com riscos pretos ao fundo que dão a impressão de estarem voando ao vento. É a segunda vez que participa do grupo e não aceitou deixar seu desenho em uma pasta com seu nome. Disse que ainda não quer ter uma pasta com seu nome no armário para guardar seus desenhos como os outros participantes. Dobra-o e o leva consigo no final da sessão.

José desenha uma praia com vários detalhes na posição horizontal da folha. No primeiro plano fez casas, prédios, um cachorro com um balãozinho escrito ' $a u$ - $a u$ '. Desenhou então uma avenida à beira-mar com um ciclista, um carro, uma pessoa correndo e duas placas: 'cuidado ciclovia' e 'prática esportiva futebol voleibol'. Na areia uma cabine onde se lê 'Posto 10 - salva vidas'. No mar uma ilha de cada lado da folha e dois surfistas. José tinha a peculiaridade de iniciar sua produção assinando com seu apelido e datando do lado direito da folha antes de começar o desenho.

Os profissionais da área da saúde mental: Silvia- $\alpha$ desenhou uma cachoeira com árvores nos dois lados, céu azul com uma ave e um sol acima; Karen- $\alpha$ desenhou um balão colorido em um céu com pássaros e um sol no meio de nuvens; Carlos- $\alpha$ fez cenas de desenhos de caverna com figuras humanas dançando em roda, mostrando uma caçada e um veado com uma mancha vermelha na barriga simbolizando que estava prenhe; Vanda- $\alpha$ desenhou um mar com dois barcos, céu azul e um grande sol; Rosa- $\alpha$ 
fez uma rede amarrada entre dois coqueiros e abaixo um coco com um canudinho. 0 terapeuta desenhou um arco-íris entre duas nuvens. A coterapeuta desenhou um grande sol nascendo com aves no céu e um gramado verde com flores.

Após todos exporem seus desenhos no quadro de cortiça e do posicionamento de todos em um semicírculo de frente ao quadro, o coordenador do grupo convidou um a um a comentar o que fizeram e sobre os outros desenhos que the chamaram a atenção, iniciando o segundo momento do grupo que chamamos verbalização.

Celso iniciou dizendo que gostava muito dos desenhos de Cristina devido às cores fortes e definidas. Falou que seu desenho é seu dia a dia, seus medicamentos, o que 'manipula' no seu dia a dia. Comentou que gostou do desenho da terapeuta e que ela sempre faz desenhos bonitos e que também gostou da árvore do desenho de Beatriz. O terapeuta comentou que achou interessante ele ter usado as cores no desenho e que percebia o quanto ele estava envolvido em seu tratamento, o que era essencial para sua melhora. Falou também que, embora tenha dito anteriormente ter dificuldade com as cores, gostou exatamente do desenho de Cristina, sempre muito colorido, o que demonstrava sua capacidade em lidar com essa dificuldade. O terapeuta disse ser essencial sua observação sobre a árvore de Beatriz, pois percebeu que ele estava em um momento importante, que muitas coisas dentro dele estavam 'brotando' e que estava satisfeito em poder acompanhar essa evolução. Ele concorda que melhorou muito, mas que ainda sente certa insegurança em fazer coisas fora do CAPS. 0 terapeuta fala que faz parte de seu desenvolvimento ir se experimentando em novas atividades e que precisava esperar o momento em que se sentirá mais confortável, reiterando que todos estariam a seu lado nesses novos passos.

Cristina afirmou que fez o jogo da velha em que ninguém ganhou, deu velha. Falou que gostou dos coqueiros com a rede, do arco-íris e do balão. O terapeuta perguntou o que ela estava pensando quando fez o desenho e ela disse não ter associado a nada, apenas quis fazer e fez. O terapeuta comentou que percebeu que ela havia utilizado pela primeira vez o giz de cera e que as cores estavam fortes e marcantes como havia comentado Celso. 
José diz que começará falando do sol do desenho da coterapeuta. Falou que 'está raiando um novo dia, dizendo bom dia'. Falou que gostou do balão: 'volta ao

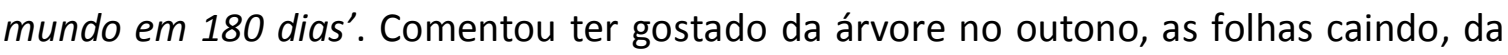
praia e da cachoeira. Contou que fez uma praia onde corria todas as manhãs. Disse que o arco-íris está 'bem expressivo'. Voltou a falar de seu desenho, descrevendo que as casas estão de frente para o mar, que tem o posto de salva-vidas e comentou que tinha 23 anos nessa época, tinha muitos planos que não conseguiu realizar. 'Como hoje é dia 23 eu queria retratar esses sonhos. O sonho continua, mas muita coisa se perdeu' (sic). 0 terapeuta comentou que achou interessante a associação da idade que ele tinha na época em que frequentava essa praia e o dia em que estávamos e que os sonhos daquele tempo podem não ser os mesmos, mas que podia sonhar outras coisas hoje e que a lembrança daquele momento não se perdera. Comentou que os sonhos muito 'idealizados' são difíceis de acontecer. O terapeuta disse que talvez agora, após a passagem do tempo, ele percebera que talvez tenha que pensar em coisas mais possíveis de acontecer, para que seus sonhos se transformassem em planos, em projetos e que possam se concretizar. Ele agradeceu e concordou. Luiza comentou que fez um monte de folhas e que todos os desenhos estão bonitos. O terapeuta disse que gostou muito de seu desenho, as diferentes formas das folhas, as diferentes tonalidades que utilizou e a impressão de que pareciam estar em movimento. A postura cabisbaixa de Luiza modificou-se nesse momento, ela levantou a cabeça sentando-se em posição ereta na cadeira. Sorriu e disse não querer comentar mais nada.

Maria comentou que fez dois rostos: o de cima chorando que representava o dia anterior em que estava triste. O relógio representou o tempo, que tem que dar tempo ao tempo para melhorar. Contou que mesmo tendo ficado nervosa conseguiu tomar a medicação dentro do que havia sido especificado, não precisando aumentar por conta própria por achar que não seria suficiente para enfrentar aquele momento. Disse que colocou o relógio mais perto do rosto feliz, pois achava que assim estaria mais próxima do momento em que seria mais feliz do que triste. A cor verde do relógio significava a esperança e a paciência. Comentou que 'para tudo há um tempo determinado. Parar de perseverar a gente não pode'(sic). O terapeuta perguntou qual o motivo do relógio estar marcando três horas e mostra que a numeração parece não ter uma sequência lógica, 
dando a impressão de que o relógio marcava horas para frente e para trás. Ela se surpreendeu, pois não havia percebido esses detalhes. Associou então que a hora marcada é o horário em que vai à igreja, lugar em que se sentia muito bem. $O$ terapeuta comentou ter percebido que ela utilizou a palavra perseverar, que poderia estar associada a sua constante luta em melhorar, no entanto, também podia significar uma luta para deixar as coisas no mesmo lugar, motivo pelo qual o relógio parecia ir para frente e para trás.

Maria concordou e disse ter muita dificuldade frente às mudanças, mesmo aquelas que pareciam ser para melhorar. O terapeuta observou que o medo do desconhecido é algo que pode ser compartilhado com todo ser humano, mas que no momento em que nos arriscamos e o enfrentamos podemos nos surpreender e nos sentir melhor. Reiterou que o grupo estava a seu lado para auxiliá-la nesse momento. Celso disse que compreendera o que ela estava sentindo e que a apoiava.

Beatriz começou a descrever os detalhes de seu desenho. 'É só um desenho. Um beija-flor, um avião, um óvni, pássaros' (sic). Comentou que gostou do desenho de Cristina, pois no final ninguém ganhara. Gostou do tufão de folhas de Luiza. A cachoeira desenhada por Silvia- $\alpha$ remeteu a cidade de Foz do Iguaçu. O desenho do Carlos- $\alpha$ parecia desenho das cavernas, primitivos. Beatriz gostou do desenho da Vanda- $\alpha$, já que parecia haver uma 'textura' no mar. Falou que achava que Celso melhorara vendo seu desenho com cores. Ao ver o balão lembrou de outro paciente do CAPS. O desenho da Rosa- $\alpha$ deu-Ihe a impressão de que havia alguém dormindo dentro da rede.

Silvia- $\alpha$ contou que desenhou um lugar que visitara no feriado. Disse que gostou das folhas ao vento de Luiza, da paisagem de Beatriz e da ideia do desenho de José.

Karen- $\alpha$ disse que fez um balão com um menininho feliz dentro, pois via agora o mundo de um ângulo diferente. Achou interessante o desenho da Beatriz e ficou impressionada com a definição das linhas do desenho de Cristina, pelo uso de giz de cera. Gostou do significado do desenho de Maria. 
Rosa- $\alpha$ contou que quis retratar um momento tranquilo necessário no dia a dia . Comentou que achou os desenhos muito coloridos, paisagens, que o painel havia ficado muito bonito.

Carlos- $\alpha$ comentou que desenhara um sítio arqueológico, um desenho rupestre, dos povos antigos, uma dança circular e que desenhara um animal com a mancha vermelha na barriga por ter lido que era um sinal de que o animal estava prenhe. Comentou ter gostado muito do desenho de Maria e que as mudanças não aconteciam de uma hora para outra.

Vanda- $\alpha$ falou que desenhou o dia seguinte do feriado numa cidade praiana. Comentou ter gostado do desenho do Carlos- $\alpha$ e da paisagem de Beatriz.

A coterapeuta contou que desenhou o sol nascendo e o início da manhã representando nosso encontro. Disse que sua intenção era passar tranquilidade. Comentou que no desenho de Beatriz chamou a atenção o fato de haver muitas coisas acontecendo e que os outros desenhos estavam muito interessantes.

O terapeuta comenta que fez o arco-íris inspirado no comentário inicial de Celso sobre as cores, e que achava o arco-íris uma das coisas mais bonitas da natureza. Oabservara que o grupo havia trabalhado bastante naquela manhã e que os desenhos haviam ficado muito bonitos e significativos. Agradeceu então a participação e presença de todos no Ateliê, encerrando a sessão.

O Ateliê faz parte de muitas outras atividades grupais desenvolvidas no CAPS UNIFESP. Oferece aos pacientes, praticamente impossibilitados de viver em harmonia com suas dificuldades pessoais e também com suas famílias e com a sociedade, novas possibilidades de convívio e de expressão.

A técnica é logo superada pela escuta compreensiva e o diálogo compartilhado entre mundos tão distintos e ao mesmo tempo semelhantes. Nesse sentido, estamos posicionados em comunidade de destino, como descreve Safra (2004). Temos o objetivo primeiro de compreender a realidade que cada um experimenta e acompanhar as vivências que se apresentam semana a semana. Essa ação de compreensão empática é de suma importância para esses pacientes, que não raras vezes relatam uma falta de 
acolhimento importante por quem convive com eles. O trato é afetivo, mais que racional. Safra (2006, p.30) afirma que "a dimensão afetiva é uma forma de compreensão". Trabalhar nesta perspectiva é estar aberto ao outro, afetivamente, empaticamente e em devoção.

Ao optar pela noção de Sobórnost, não é tanto a técnica utilizada que nos interessa, mas o modo como se manejam situações difíceis que pacientes com sofrimentos extremos nos apresentam. Trabalhamos abrindo espaços para acolher o mistério, o incompreensível, testemunhando o sem sentido e o ainda não vivido, a esperança dos pacientes, o que a concepção de Sobórnost revela de modo contundente.

Em um tempo no qual a técnica é fruto da tecnologia, o tempo é vivido sempre como escasso para fazer tudo o que se tem a fazer. A aceleração do tempo é um impedimento a deter-se com calma, tranquilidade e serenidade no cotidiano, onde o espaço do ambiente de uma metrópole não se harmoniza com as necessidades fundamentais de cada ser que exprime o seu espaço interior.

Observamos que o uso do desenho pode auxiliar, pois facilita a "com-vivência" de um tempo distinto ao cronológico, um tempo que se ancora no vivido e que facilita o uso da linguagem distinta da cotidiana Acreditamos que os pacientes podem estar inaugurando dentro de si experiências antes poucas vezes sentidas nas relações.

Se cada um dos pacientes puder utilizar as marcas deixadas por estas experiências, por este procedimento intermediário de acesso aos peculiares modos de ser, as experiências podem se fixar como memória, como lembrança e poderão ser usadas, quando menos perceberem; e, quem sabe, quando mais necessitarem?

Ao trabalharmos no vértice da comunidade de destino, cada paciente e participante do grupo é compreendido na singularização da vida de muitos, de seus familiares, das gerações anteriores, podendo indicar pressentimentos daqueles que virão. Do ponto de vista transgeracional, os participantes põem-se em direção ao que ainda não é. Ao ouvirmos os participantes formularem as questões do seu destino, estamos ouvindo o sofrimento de um e de todos. 
Esse diálogo entre gerações ou segmentos sobre as questões do destino humano é realizado por meio dos desenhos e da linguagem. Como expressa Safra (2004), a linguagem se apresenta como poesia e revela uma ação - como os desenhos! Os cuidados que os terapeutas oferecem também são uma moradia para o ethos humano.

Observo que o Ateliê é uma atividade que propõe uma criação compartilhada, realizada em um ambiente disponível para acolher e compreender o que está sendo trazido e experimentado. Esse atendimento clínico em grupo busca favorecer o aparecimento de vivências que podem ser organizadoras. Partindo em um primeiro momento da imagem que é transformada em palavra e daí em associações, seguimos um caminho de interesse conjunto de cada gesto humano.

No momento em que todos nós - pacientes e profissionais - nos debruçamos em uma tarefa comum que é proposta - desenhar e conversar sobre o que foi feito há espaço para o singular e para o que há de comum entre nossas existências.

Pode-se observar nessa forma de trabalho que o profissional não se coloca em uma postura de que sabe algo a mais do que o paciente ou mesmo de que tem uma melhor compreensão sobre o sofrimento que é trazido. Estamos todos juntos procurando uma forma de ajudar aquele que sofre, utilizando nosso conhecimento integrado naquilo que nos faz humanos.

Se os terapeutas têm esperanças o encontro gerará frutos. As sementes florescerão e nosso trabalho terá sua validade - observada na humanização do contato direto com aqueles que sofrem fechamentos de si, angústias de aniquilação e, principalmente, terror pelo que impossibilita o vir a ser.

\subsection{Estudo de um caso ${ }^{72}$ com depressão: acompanhamento de quatro anos}

Anteriormente apresentei uma compreensão clínica do ateliê de pintura a partir do conceito comunitário de sobórnost, desenvolvido por Safra (2004). Expus em

\footnotetext{
72 Publicado em Revista Eletrônica On-line. Antúnez, A.E.A.; Freitas, K.V; Santoantonio, J.; Amparo, D.M.; Franco, R.R.C. (2012). Análise fenômeno-estrutural de um caso de depressão utilizando desenhos: acompanhamento psicológico em ateliê de pintura e expressão. Revista Psicopatologia Fenomenológica Contemporânea 1(1), 34-63, julho de 2012. Nesta tese, apresenta-se parte desse trabalho.
} 
seguida como acontece um atendimento em grupo dentro de um centro de atenção psicossocial. Neste momento apresentarei um caso acompanhado em grupo, mostrando o potencial que esta atividade clínica grupal oferece ao acompanhar a evolução individual de uma paciente ao longo do tempo.

Apresento a análise fenômeno-estrutural dos desenhos de uma pessoa diagnosticada pelo psiquiatra com depressão e transtorno de ansiedade generalizada TAG - ao longo de quatro anos. Trata-se de uma mulher de 47 anos que começa a apresentar dificuldades de relacionamento em seu trabalho. Procura ajuda em um hospital universitário, é diagnosticada e encaminhada à Clínica Psicológica Durval Marcondes do IPUSP para realizar psicoterapia. Não encontrando vaga naquele momento para atendimento, se interessa por uma pesquisa ${ }^{73}$ clínica: Ateliê de Desenho de Livre Expressão - procedimento intermediário no acompanhamento terapêutico em grupo.

O intuito de acompanhá-la durante anos em atendimento de uma hora e meia em grupo, teve o objetivo de verificar a utilidade dessa modalidade clínica de atendimento em grupo e se aproximar de seu modo de ser e de se expressar, conhecendo assim quem é e como reage a esta modalidade clínica ao longo do tempo.

O método usado é qualitativo e se refere a um estudo de caso de acordo com a análise fenômeno-estrutural associado ao trabalho clínico de atendimento em grupo. 0 primeiro busca conhecer, por meio da linguagem verbal e da expressão de imagens no desenho, os mecanismos essenciais da linguagem, sendo os principais: o mecanismo de ligação e corte, a vivência espacial e temporal e a qualidade do contato vital ou desvitalizado com a realidade. O segundo busca compreender o paciente a partir de seu idioma pessoal e da sua semântica peculiar. Assim, um método observa e revela o vivido, o outro implica uma ética no encontro humano, encontro intersubjetivo, onde a solidariedade e a amizade ontológicas são fundamentais no cuidado e acompanhamento de alguém, a partir de um registro ontológico, relativo ao ser em si mesmo, em sua dimensão ampla e fundamental. Observamos que ao longo de quatro anos - dois anos a mais da proposta inicial - já que pacientes solicitaram continuidade

\footnotetext{
${ }^{73}$ Pesquisa com apoio do CNPq. Processo número 400163/2007-1.
} 
na participação do grupo após os dois primeiros anos - a paciente pôde expressar, por meio dos desenhos e dos comentários em relação aos mesmos, facetas de sua história que jamais haviam sido dialogados com alguém.

No início desenhava conteúdos da natureza e se impressionava porque não conseguia desenhar figuras humanas que observava que outras pessoas faziam mas, com o passar do tempo, alcançou essa possibilidade. Poder expressar suas vivências interiores permitiu que compreendesse seu próprio tempo e ritmo, sua biografia associada aos momentos atuais. Desenha com cores, formas muito bem definidas, contornos realizados cuidadosamente, envolvendo-se na atividade. Os desenhos mais recorrentes se referem às arvores grandes, fortes, cortadas (mecanismo de corte), onde em seus galhos grossos, nascem folhas ou há ninhos com pássaros (mecanismo de ligação). Tanto racionalidade como sensibilidade estão presentes em seu modo de ser.

Discutimos em conversas semanais que, ao compreendermos as rupturas que se revelavam nos desenhos tais como aparecem em sua vida, abrem-se possibilidades de crescimento e amadurecimento. Assim, após dois anos de trabalho, seus sintomas estavam em remissão, solicitando o prosseguimento dos atendimentos no Ateliê. A paciente esteve um ano e meio sem uso de medicação e com acompanhamento psiquiátrico de controle mais espaçado.

A depressão é um quadro bem conhecido na população e é considerado um transtorno que gera grande sofrimento. $O$ tratamento costuma associar a intervenção medicamentosa e a psicoterapia. Nosso intuito não é nos aprofundar na descrição sintomatológica na qual se baseia a maioria dos estudos atuais, já que sabemos que o paciente, mesmo sem saber muitas vezes nomear o que sente, não se vê realmente compreendido em sua existência e subjetividade com a simples explicação diagnóstica. Queremos nos aproximar da pessoa que sofre a dor de uma tristeza que permanece, da falta de ânimo e vitalidade em sua vida como um todo, da falta de sentido no que faz no seu dia a dia, não apenas nas evidências comportamentais. Como proporcionar um encontro com aquele que se vê aprisionado em seu sofrimento a não ser nos aproximando dessa prisão? 
De acordo com Barthélémy ${ }^{74}$ (2006), o que importa na aproximação fenômenoestrutural em psicopatologia é, mais do que o estudo de inumeráveis casos, a compreensão intuitiva e profunda de alguns casos particulares. Assim, nos interessa conhecer como essa senhora vive as dificuldades que a afetam, como as descreve e como vive suas experiências. Mais do que sua depressão, interessa-nos sua própria vida.

Esse trabalho é o prosseguimento de um estudo ${ }^{75}$ anterior (Antúnez \& Santoantonio $\left.^{76}, 2010\right)$, no qual foi utilizada uma breve análise da linguagem de algumas pranchas do método de Rorschach e do teste de Apercepção Temática, bem como o resultado de uma prova de inteligência em três momentos distintos, antes de iniciar o Ateliê, após um e dois anos. Seguimos a apresentação de alguns desenhos selecionados pela importância que têm na evolução dessa paciente.

No primeiro ano de trabalho a paciente desenhava árvores grandes, com galhos cortados, nos quais nasciam pequenas folhas. A natureza sempre se apresentou como sendo de grande interesse para ela. Seus traços finos, bem delimitados, mostram formas preenchidas por muitas cores. Chamava a atenção o modo calmo ou até vagaroso como fazia seus desenhos. Os outros componentes do grupo já haviam terminado e ela continuava desenhando, não conseguia terminar na média temporal do grupo.

No primeiro tempo do Ateliê, aquele em que todos desenham, estabelecia-se um silêncio. Este silêncio lhe era muito desconfortante. A paciente perguntava por que ninguém falava, todos continuavam em silêncio. Eu apenas comentava que todos estavam concentrados na tarefa. Após dois anos, ela mesma já tolerava bem trabalhar dessa forma sem se incomodar tanto. No terceiro ano, ela já experimenta permanecer em silêncio, o que para ela foi uma vitória.

\footnotetext{
74 Barthélémy, J.M. (2006). Importance et extension de l'approche qualitative dans la méthode phenóméno-structurale en psychopathologie. Bull. Soc. Sci. Méd. 2, 249-264.

${ }^{75}$ Aprovado pelo Comitê de Ética em Pesquisa com Seres Humanos no IPUSP em 04/12/2006.

${ }^{76}$ Santoantonio, J \& Antúnez, A. E. A. A. (2010). Ateliê de desenho e Rorschach: estudo fenômenoestrutural. Paideia. jan.-abr., Vol. 20, No. 45, 117-122.
} 
No segundo momento do Ateliê, quando se conversa sobre a produção de imagens, a paciente mostra muita capacidade de simbolização, já que seus desenhos sempre representam algo de que ela necessita ou desejava falar. Ao olhar os outros desenhos ela se perguntava o motivo de não conseguir desenhar figuras humanas, porém, com o passar dos anos, ela começou a desenhar anjos e depois, pessoas. Mas não qualquer pessoa: ela começou a se representar no desenho.

Na perspectiva do Ateliê de Pintura de Livre Expressão (Santoantonio \& Antúnez, 2010), não interpretamos os desenhos sem a presença do seu criador, o que nos interessa é a revelação por parte da paciente dos motivos que a levaram a fazer tal desenho, de modo que a expressão verbal desvela o segredo que a imagem guarda. Qualquer interpretação fora desse contexto seria pura manifestação da percepção do observador, não do paciente. Apresentaremos a seguir alguns desenhos com a verbalização da paciente ${ }^{77}$ :

(1) Desenho do muro com a frase: Eu mereço ser feliz

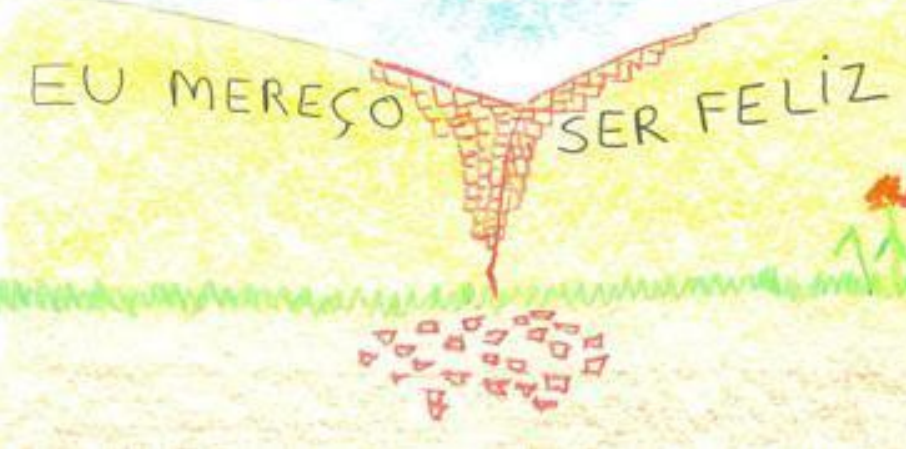

“Esse muro é a minha vida. Minha mãe dizia e diz que a nossa família veio para sofrer... Mas eu não quero acreditar nisso. E eu tenho sentido que eu também mereço ser feliz, mesmo com os problemas e dificuldades do dia a dia. Com a sua ajuda, Andrés, e com esse nosso grupo, eu estou conseguindo derrubar esse muro aos poucos, para ver o que

\footnotetext{
77 A quem agradeço a oportunidade de expor parte do fruto de nossos encontros, com seu consentimento. A ela, minha gratidão.
} 
tem do outro lado e esse muro também é a vida, e eu creio que do outro lado desse muro devem ter coisas boas".

(2) Desenho do muro com as frases: Você é uma peste igual ao seu pai... Eu preferiria que você tivesse um câncer... Nenhum homem presta... É melhor nem tentar... Você só atrapalha... A nossa família veio pra sofrer...

"Nesse muro eu escrevi frases que eu ouvi e ouço da minha mãe desde quando eu era pequena. Como essas frases me fizeram e me fazem mal.... É por isso que muitas vezes eu sinto medo de tentar fazer alguma coisa, acho que não vou conseguir. Eu nunca vi o meu pai. Quando eu era pequena e minha mãe estava nervosa e dizia que eu era uma peste igual ao meu pai, hoje eu penso: se eu era igual ao meu pai, ele não deve ser tão ruim, pois eu também tenho coisas boas em mim... Na frase sobre o câncer, eu a ouvi quando eu the disse que estava grávida".

Os dois primeiros desenhos são representações gráficas que assumem a mesma função da folha de papel em branco: o muro é o pano de fundo para expor e registrar um pensamento que é carregado de sofrimento. Por intermédio de palavras a paciente revela valores emocionais externos que perturbam o seu equilíbrio. 
A expressão concreta das palavras pichadas no muro registra o desconforto interno atual e um desejo atemporal de conforto interno que é entendido pela paciente como felicidade.

Nesses desenhos a paciente apresenta sua percepção da relação com a mãe. A imagem que ela faz dela mesma traz a presença da imagem e memória que tem de sua mãe. Em especial, no segundo desenho, observa-se o registro de uma mãe vilã e culpada pelo destino da filha, que também pode desenvolver algo bom dentro de si, mesmo diante dessa adversidade.

Nos diálogos em grupo ela pôde ir aos poucos se discriminando das falas de sua mãe que permaneceram em sua memória. A paciente nunca havia conversado essas questões com alguém e, no grupo, encontrou um espaço de interlocução e acolhimento. Com o passar do tempo, tanto as imagens e os sofrimentos que carregava puderam ser expressos ao seu próprio ritmo. Essa possibilidade revelou a importância e força das reflexões que, uma vez compartilhadas, promovem novos sentidos para si.

O mecanismo de corte aparece na imagem do primeiro desenho, na cisão do muro que separa e protege, bem como nos estilhaços no chão. Apesar da dureza do muro e da vida, a paciente não a considera como sendo apenas investida de sofrimento, ou seja, ela diz "nossa família veio para sofrer... Mas eu não quero acreditar nisso. E eu tenho sentido que eu também mereço ser feliz". Há sempre uma força que palpita em sua personalidade, não há apenas sofrimento, mas há também a felicidade, o prazer, a satisfação, mecanismo de compensação fenomenológico. Ao mencionar ao terapeuta: "com a sua ajuda (...) eu estou conseguindo derrubar esse muro...", verificamos como a "ajuda" - mecanismo de ligação - permite que ela possa "derrubar" - usar o mecanismo de corte - barreiras que não permitiram que ela pudesse viver outras facetas da sua existência. Sua linguagem verbal mostra que tais mecanismos (ligação e corte) coexistem e se alternam, aproximando-se da possibilidade de integração.

O desenho dois mostra a importância deste grupo de trabalho, cujo objetivo terapêutico é mais amplo que apenas observar desenhos e verbalizações, mas sim se 
colocar em disponibilidade para ser usado pelo paciente, como ele possa e como nós pudermos. Expressar vivências que estavam aprisionadas em seu ser mais íntimo permitiu mais que uma descarga, mas um colocar em movimento seus traumas. Um mês após a realização desse desenho ela comenta que ficou pensando sobre essas coisas e percebeu que sua mãe foi realmente dura com ela e com seu pai. Ao falar sobre o desenho se remete ao pai e consegue questionar o que a própria mãe lhe dizia, pois ela se colocava no lugar dele, ao pensar de si mesma "se eu era igual ao meu pai, ele não deve ser tão ruim, pois eu também tenho coisas boas em mim.." Assim, ela percebe que não é apenas habitada pelo "ruim", mas também pelas "coisas boas". A frase "sobre o câncer, eu a ouvi quando eu lhe disse que estava grávida" traz uma carga dramática impressionante. Quando ela revela à mãe sua fecundidade ao carregar uma Vida dentro de si, a mãe lhe diz que "preferia que você tivesse um câncer". O "câncer" poderia estar agindo aqui como uma cisão com a própria vida. Ao conversarmos sobre esses assuntos, um mês depois, é a capacidade de perdoar o que nos chama atenção, possibilidade conquistada na alteridade.

(3) Desenho com vários sacos de lixo, materiais de limpeza, vassouras, rodo e uma janela com uma planta e um gatinho:

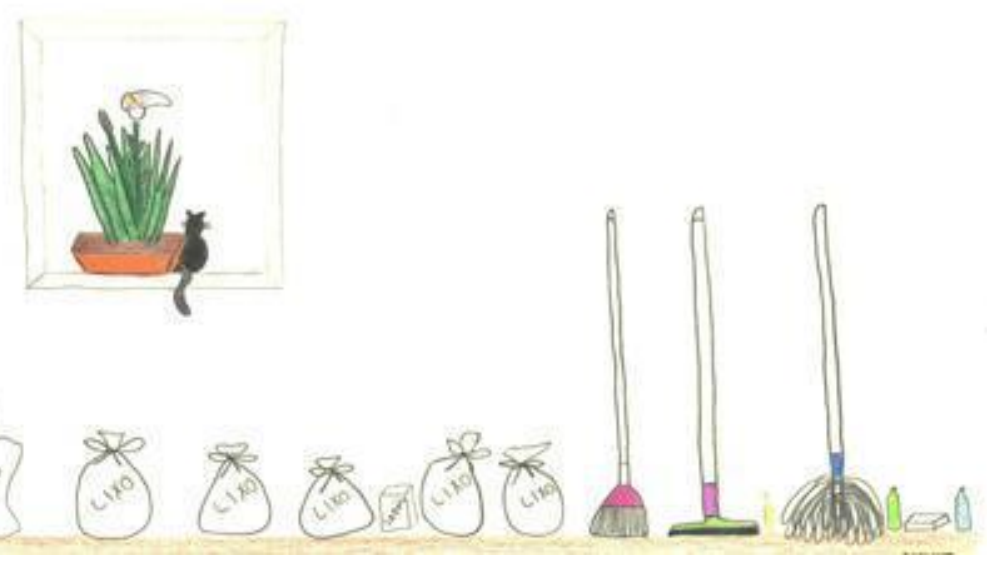


"Eu estou tentando arrumar minhas coisas, o meu quarto. Consegui limpá-lo e joguei muitas coisas que não serviam. Aquele vaso é uma flor que eu tenho, e essa flor abre e no mesmo dia fecha. Sempre que tem uma flor, eu estou em $X$ (outra cidade) na casa da minha mãe, eu nunca consigo ver a minha flor aberta. Mas esta semana eu estava em casa aqui em São Paulo e consegui ver minha flor. Esse gatinho é o Chiquinho, nosso gatinho que mora com a minha mãe".

No terceiro desenho, com vários sacos de lixo, materiais de limpeza, vassouras, rodo e uma janela com uma planta e um gatinho, a paciente expressa seus pensamentos, sentimentos e ações. As cores são discretas, a organização espacial é bem simétrica, a ausência da cinestesia é reforçada pelos objetos de limpeza encostados na parede e pelo gato que olha pela janela. Aparece a possibilidade de ver algo bom que nunca foi possível antes: o desabrochar da flor e de facetas de si mesma.

A presença do mecanismo de corte assume um papel importante e eficaz na organização desse desenho. Os sacos de lixo bem fechados, atados e cheios, sinalizam que nada transbordou ou vazou, delimitando muito bem a fronteira do que está dentro do saco de lixo e que não serve mais, por isso pode ser descartado. A organização espacial e temporal é nítida e sentida imediatamente pela paciente que finaliza seu registro verbal de forma agradável e afetiva, referindo-se à flor e ao gatinho Chiquinho.

Há uma união de aspectos relacionados à satisfação entre o que existe em sua casa (flor) e na casa de sua mãe (gato) incluídos na mesma imagem. A mãe aqui pode também apresentar aspectos bons. A importância da natureza e do animal parece se relacionar à Vida que apresentam e ao silêncio que revelam. Já o contato com o humano materno é carregado de dor.

Esse desenho mostra também suas intenções de organizar seu quarto. Ela mora sozinha e por vezes conta ao grupo que mantém seu quarto desorganizado, que não consegue organizá-lo. É a organização espacial que tenta resolver, talvez na relação que tem consigo mesma e os conteúdos a respeito de sua mãe. São interessantes as 
noções de abertura e fechamento que expressa, ao estar próxima de sua mãe é o fechamento que se impõe mas, ao estar distante e só, a flor se abre! É justamente essa vivência da distância espacial que permite a ela rever sua vida, se discriminar de sua mãe. Quatro anos depois, a paciente retorna ao interior para cuidar da mãe, necessitada de cuidados intensivos, e revela que algo mudou, que não sentia mais aquele ódio por ela, que não esquece o que ela lhe falava, mas que agora podia ver como ela também deve ter sofrido em sua vida.

(4) Desenho com pasta, escova de dente fio dental e um presente:

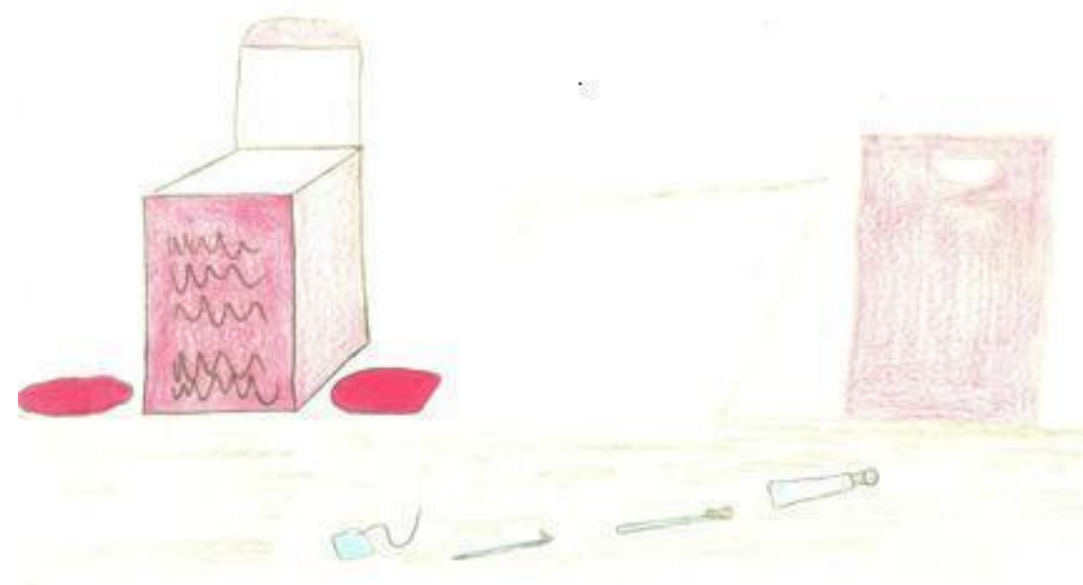

"Bem, eu morro de medo de ir ao dentista. Quando eu tinha dez anos, eu ia ao dentista sem medo, mas naquele dia eu falei para a minha mãe que eu não queria ir. Quando cheguei lá, não conseguia deixar o dentista tratar os meus dentes. Minha mãe me levou ao banheiro, me deu uma surra, até que o dentista interferiu e disse que ela não deveria fazer isso, que seria pior. Desde esse dia então eu comecei a ter pavor de ir ao dentista. Meus dentes pioraram, e aos 13 anos, tive de ser internada no Hospital das Clínicas, tomar uma anestesia geral e eles arrancaram vários dos meus dentes, pois não tinha muito mais a ser feito. Desde então uso prótese dentária. Mas nesta semana eu estava na casa da minha mãe com a minha filha, e ela me incentivou para que eu fosse ao dentista. Eu tentei ir, falei ao dentista que eu estava com muito medo, contei a 
minha história, fiz o tratamento e no fim, ele me deu um presente - uma caixa de sabonetes cor de rosa, e me disse: "Parabéns, você conseguiu! Aliás, eu sabia desde o início que você iria conseguir!"

No quarto desenho, com a pasta, escova de dente, fio dental e uma caixa de presente, a paciente mescla uma lembrança positiva e vivida no presente com uma evocação desagradável do passado. A paciente tenta eliminar o desconforto do passado, aproximando as imagens (caixa de sabonete) a uma nova experiência vivida de conquista e superação.

A produção desse desenho mostra a necessidade de confiar em alguém. Dois grandes medos aparecem, um de ir ao dentista e o outro, da violência sofrida pela mãe. Precisou ser anestesiada para cuidar dos dentes, para não sentir dor. Anos depois, nos conta que o dentista foi cuidadoso com ela, apoiando-a e reconhecendo seu enfrentamento.

O atendimento clínico em grupo, no ateliê, permitiu à paciente falar sobre esses fatos que aconteceram em sua vida para alguém interessado. Não havia muito que dizer, nem ao menos interpretar, a própria expressão e acolhimento lhe era essencial e saiu da sessão bem mais aliviada que no início do encontro. Ao compartilhar essa experiência pôde ser acolhida e reconhecida em seu sofrimento, não ocorrido apenas naquela época, mas que ela porta em si, de modo que, depois da expressão, eu passei a carregar a memória dessa experiência vivida por ela.

(5) Desenho onde tem uma cama e uma mulher dando a luz a um bebê... 


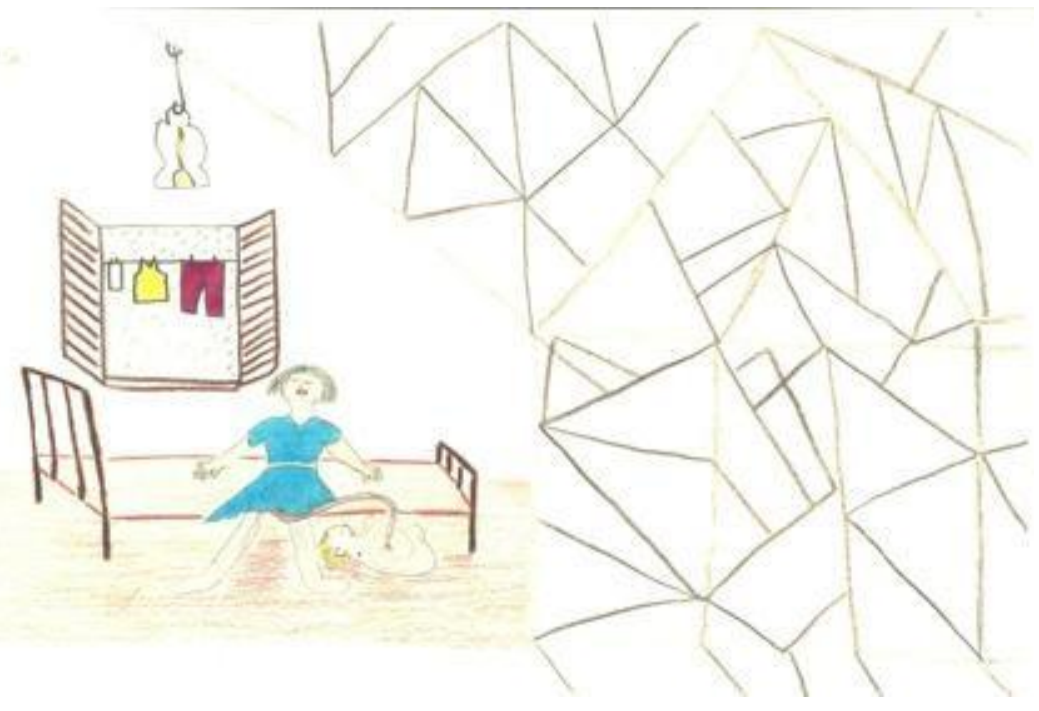

"Eu desenhei a minha mãe e eu. Eu nasci em casa. Minha mãe me contou que ela estava sozinha em casa quando eu nasci. Eu fiquei no chão por muito tempo, até que apareceu alguém para ver por que minha mãe não tinha ido trabalhar na roça naquele dia. Quando me viram no chão, foram chamar uma parteira rapidamente. Quando ela chegou, cuidou de mim e da minha mãe. Tinham roupas no varal, ia começar a chover e aí minha mãe se levantou e foi tirar a roupa do varal".

Nesse desenho, onde ha uma cama e uma mulher dando à luz um bebê, a imagem é carregada na intensidade das cores e a presença de traços abstratos que se ligam à imagem sem lógica ou razão plausível. O tempo passado e o presente se confundem, o mecanismo de corte e ligação se alterna e a paciente sente um intenso desconforto interno. O sentimento de desamparo, solidão e falta de continência marcam a imagem do nascimento. A mãe é capaz de pensar na roupa que irá molhar caso chova, mas não no bebê que acabou de nascer. O cuidado fica delegado a outra pessoa, à parteira, que se ocupa concretamente da tarefa. $\mathrm{O}$ afeto aparece no colorido das roupas, enquanto desenhava com calma muita coisa se passava dentro dela, contato com essas lembranças e preparação de como iria expressar o que the ocorria naquele momento. A cena que nos conta é de uma narrativa da mãe, que "estava sozinha em casa quando eu nasci. Eu fiquei no chão por muito tempo, até que apareceu alguém" para ajudar. A parteira cuidou de ambas e a mãe "se levantou e foi 
tirar a roupa do varal". A preocupação em tirar a roupa do varal the deu forças para se levantar mas, pelo que aparece, não tinha forças para cuidar.

(6) Desenho de um banheiro, uma mulher e uma criança:

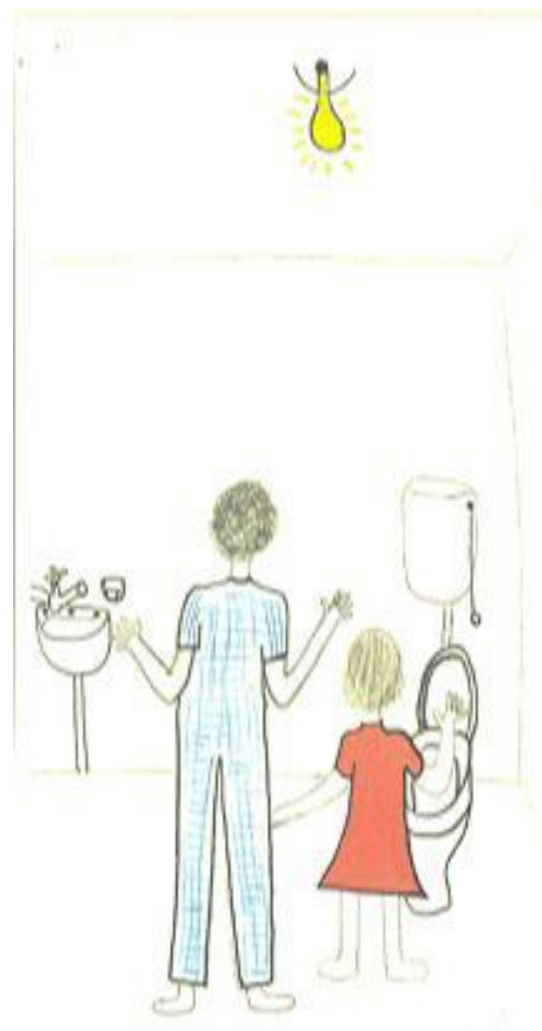

"Nesse desenho fiz eu e minha filha. Quando ela era pequena e ela fazia o número 2, dávamos tchau para o cocô, juntas...".

Na tentativa de eliminar o desconforto gerado no quinto desenho, ou mais especificamente no que essa memória mobiliza na vida de nossa paciente, ela tenta anular o impacto atordoante da imagem de seu nascimento. Faz o desenho de um banheiro, de uma mulher e uma criança, mãe e filha, que serve como um alívio e uma possibilidade de fazer algo juntas (mecanismo de ligação), mãe e filha, mudando o destino de suas histórias, em que a criança não se vê mais sozinha diante de algo importante, o que dá fôlego à paciente e leva a uma estabilização e recuperação do perdido. O novo se impõe, não só como um fato novo, mas resolve uma situação anterior. Nesse desenho a paciente aproxima a imagem da sua própria experiência de 
ser mãe. Observa-se, portanto, que o registro desagradável do dia do seu nascimento é substituído pelo registro agradável dela enquanto mãe, que acompanha, se ocupa e cuida de sua filha. Aqui observamos a manifestação do mecanismo de compensação fenomenológico para dar conta de experiências difíceis.

\section{(7) Desenho de um casal com uma criança e uma casa:}

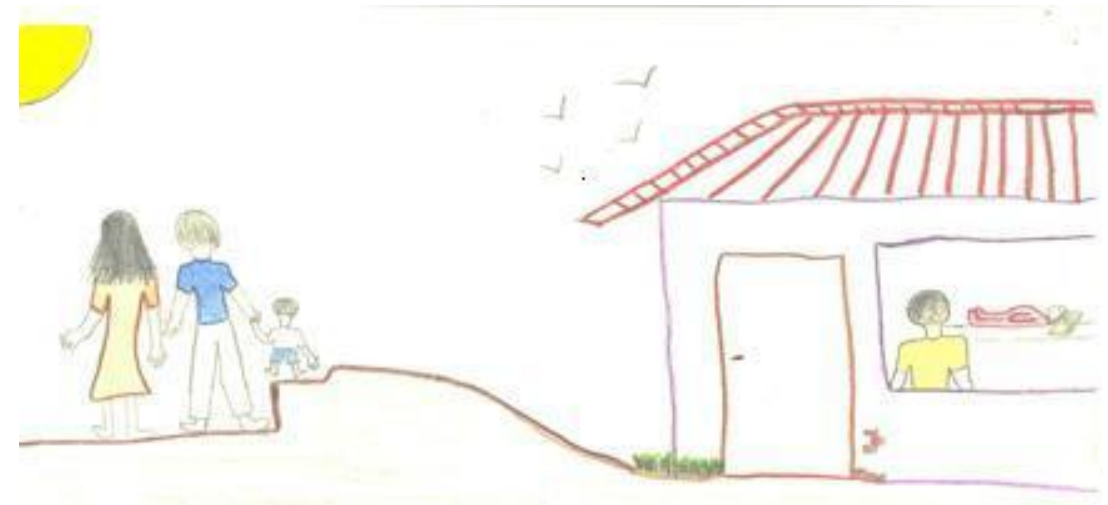

"Eu quis retratar o seguinte: Foi quando o meu pai foi embora com a melhor amiga da minha mãe e levou o meu irmão, que a minha mãe amava demais. Na casa ficamos minha mãe com 23 anos de idade e eu com apenas um mês de vida".

O ultimo desenho dessa série, um casal com uma criança e uma casa, ilustra a cinestesia que se alterna com o estático e o imóvel. O movimento do pai que se distância pelo caminho afora com outra família e se contrapõe à mãe e filha que ficam paradas e sós em casa. A filha deitada na cama representa a sua impotência diante do fato. O sentimento de abandono e rejeição também é presente no desenho.

A sequência dos desenhos quatro, cinco, seis e sete, revela a dificuldade de expressão emocional que é substituída por ideias ligadas às experiências corporais. A necessidade vivenciada de se refugiar em experiências da infância funciona como uma primeira tomada de consciência sobre o processo de adoecimento de si mesma. Para ela, compreender e reviver, por meio dos desenhos, os valores emocionais externos 
que perturbam seu equilíbrio interno, é o inicio do processo de apropriação de seu estado de saúde atual.

(8) Desenho de uma montanha, uma corda e uma pessoa:

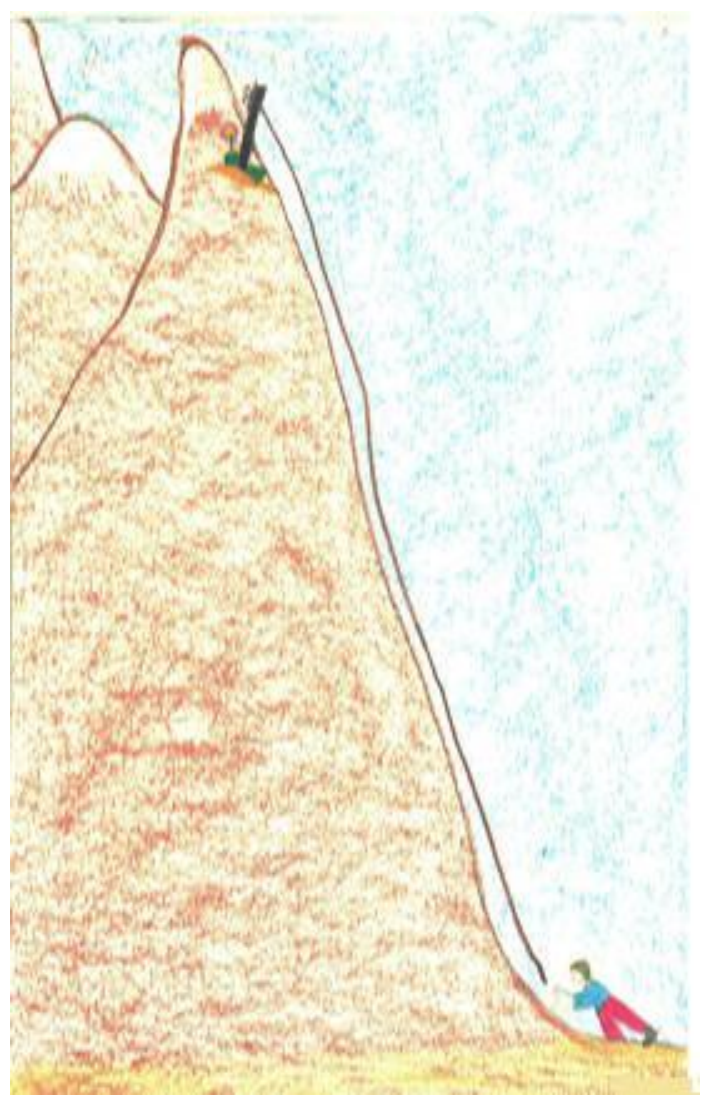

"Bem, essa montanha é a vida. Essa pessoa aí em baixo sou eu e essa corda é você, Andrés. Você é muito importante para mim. Com você, eu me sinto segura".

Ao completar três anos de atendimento, a paciente teve que se ausentar por um mês do Ateliê de Desenho, pois havia sido contratada em um novo emprego. Descontente com sua atividade nova, ela pede demissão. Ao retornar ao grupo, desenha os mesmos traços deste, no entanto, ela - a personagem que segura a corda - está a meio caminho desse morro e verbaliza a ajuda e apoio que sente nesse momento. A corda ou o terapeuta é a representação da ligação necessária entre o 
peso de seu sofrimento que precisa ser carregado para poder atravessar um grande obstáculo e poder olhar e seguir seu caminho.

(9) Desenho de um ramo de planta, com um casulo, uma lagarta e uma borboleta:

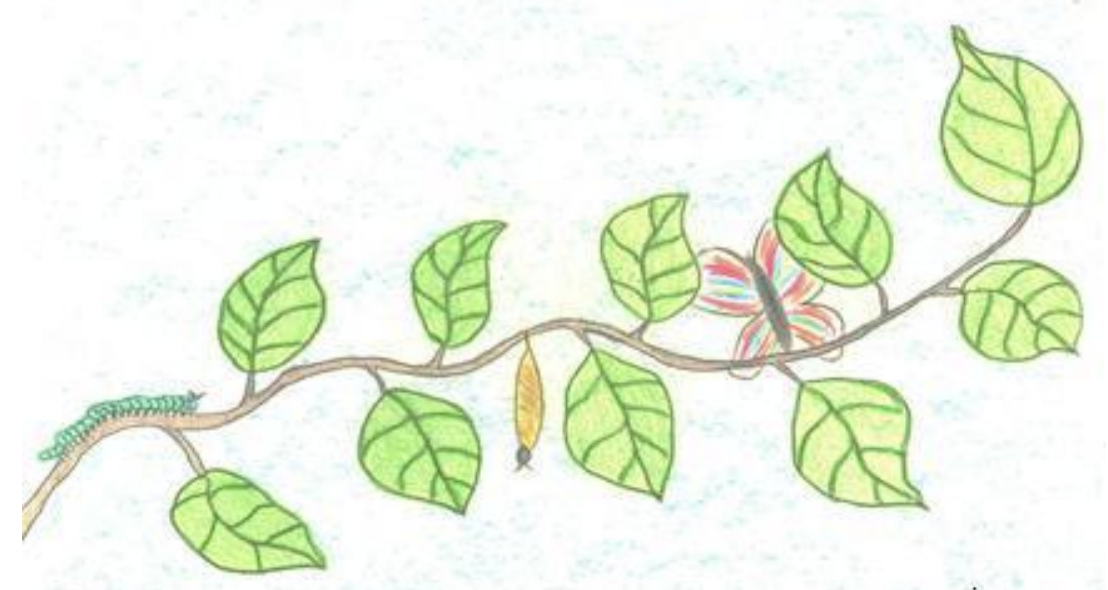

"Nesta semana, um colega nosso de trabalho faleceu. O Sr. J. era muito querido e companheiro de todos. Ele era o nosso representante no sindicato dos funcionários, era prestativo e sempre tinha palavras de incentivo para todos. Todos nós e os professores ficamos muito tristes. Ele foi fazer um exame no hospital, para ver se estava com câncer ou não, e após o exame, sem antes saber o resultado, começou a passar mal e teve uma parada cardíaca. Esse desenho significa a vida, as fases da vida e é uma homenagem minha para ele".

Nos desenhos 8 e 9, o concreto e o sensorial são mais suavizados e o pensamento abstrato aparece com mais força.

No desenho de uma montanha, uma corda e uma pessoa, o mecanismo de ligação é bem nítido e funciona de forma adaptada e conectada com a experiência da realidade. A cinestesia e a presença das cores trazem uma harmonia na estética do 
desenho. A paciente compreende a sua fragilidade psíquica e ao mesmo tempo demonstra as forças internas ativadas e que lutam contra a fragilidade estrutural.

Quando verbalizou isso no grupo eu recebi um impacto em meu corpo, fui tomado pela surpresa e pelo conhecimento do valor que tenho para esta paciente. A possibilidade de fazer eco e ter ressonâncias de ambas as partes mostram como o potencial guardado dentro de cada pessoa pode movimentar a vida.

No último desenho, um ramo de planta, com um casulo, uma lagarta e uma borboleta, a paciente representa o processo de transformação, também carregado de cinestesia e sensorialidade. O seu discurso é associado com a evolução da vida que pode ser traduzido como a evolução de seu percurso nela.

A sequência dos desenhos é um dado bastante significativo pra compreender a personalidade da paciente que lentamente se conecta com a sua própria história e experiência vivida.

Nos desenhos quatro, cinco, seis e sete, observam-se associações da infância e da relação mãe-filha com saltos de um registro para outro. O desconforto mobilizado por lembranças do passado é substituído por imagens e percepções mais concretas e sensoriais.

Dessa forma os desenhos demonstram uma evolução gradual que pode ser percebida na qualidade e organização dos desenhos e do discurso associado a cada desenho. Assim, a análise fenômeno-estrutural é um método de investigação que compreende o modo como a pessoa se expressa, seja de forma verbal ou gráfica, revelando o valor da experiência, trazendo à tona a percepção subjetiva diante do sofrimento existente.

Como pudemos observar, os desenhos mostram as preocupações e os interesses com os detalhes, sendo realizados com ritmo lento, com cuidado e atenção. As cores são suaves e presentes, indicando como expressa seus afetos na atividade de desenho livre. Nos desenhos há pouca expressão de movimento, denotando uma racionalidade predominando sobre a sensorialidade. Esta existe e se expressa em forma de sofrimento e de desamparo, que foram diminuindo, ao mesmo tempo em 
que desenvolvia possibilidades associativas entre os acontecimentos depressivos e sua história, do que não se apropriava no início do acompanhamento psicológico em grupo.

Em suas verbalizações, a paciente relacionou suas vivências com as imagens, experimentando também a possibilidade de se colocar no lugar do outro, dirigindo-se a uma abertura em direção ao porvir, à alteridade e ao reconhecimento do outro. Por meio dos desenhos nos deparamos com surpresas ao longo desse processo, decorrentes de uma ação terapêutica, através de uma compreensão empática e de ações solidárias ao modo de ser do outro.

Por meio dos desenhos e das associações que os acompanham nos cuidados terapêuticos, a paciente gradativamente apropriou-se da possibilidade de reconhecer o outro e integrar suas experiências vividas, retomando aspectos de sua história passada, atual e suas expectativas futuras.

Um dos mais recentes mostra duas pessoas em cima de um morro olhando para o outro lado, somos eu e ela. Compreendo que ela está podendo lidar com a sua vida e a de sua mãe, na intersubjetividade familiar, estando mais segura de suas escolhas; como a de voltar a residir no interior, para cuidar de sua mãe. Cuidando de si, pode cuidar do outro.

Essa investigação-clínica ao longo do tempo indica os seguintes achados:

Os mecanismos de ligação e corte se encontram também nas vivências depressivas, não só nas epiléticas e esquizofrênicas, mas em qualquer estrutura humana. Observamos em seus desenhos que, a cada ruptura ou cisão, o mecanismo de ligação aparece, coesão apreendida pela análise qualitativa (Minkowska, 1956).

A análise da linguagem verbal, tanto quanto a observada no Rorschach por Minkowska (1956), pode ser apreciada na linguagem relacional diante da produção de 
desenhos, tal como Minkowski ${ }^{78}$ (1965) estudou minuciosamente nos discursos de seus pacientes.

No ateliê de pintura de livre expressão pudemos acompanhar a sucessão de imagens ao longo do tempo, como ocorre no método de Rorschach. Os desenhos acompanham a evolução estrutural (Helman ${ }^{79}$, 1983). Toda estrutura tem movimento, não é estática como se entende no senso comum. Os desenhos mostram o campo do imaginário da paciente e, na sua linguagem expressiva, a fonte dos estudos fenômenoestruturais (Helman ${ }^{80}$, 1998). Desenhar livremente permitiu que a paciente ordenasse as coisas em seu estilo pessoal. Há um contato cada vez mais dinâmico com a realidade por parte da paciente; no início sentia depressão, hoje ela compreende o porquê da depressão, pois ela luta para manter uma relação mais dinâmica com a realidade, que agora Ihe fornece uma condição mais viva, acompanhada e reconhecida à sua vida.

No ateliê é possível acompanhar o processo de criação quando ele aparece, mas esse processo precisa se dirigir a alguém (Ternoy, 1997), pois tal energia tem suas raízes relacionadas à necessidade de expressão e de comunicação. Os desenhos espontâneos mostram as raízes de sua vida afetiva; só foi possível conhecer sua afetividade pelo esforço de compenetração e compreensão terapêuticas (Minkowski ${ }^{81}$, 1999).

A paciente dá sentido ao que faz, corroborando Ternoy (1999), que afirma que ser é fazer e dar sentido ao que foi feito. O traço nessa paciente representa importantes facetas de sua vida, não só suas imagens, mas aquilo que ela é (Picasso, 1935). Seus desenhos indicam o uso de cores adequadas, com tom afetivo de seus aspectos sensoriais e a falta de movimento e a precisão geométrica, seu tom racional (Minkowska, 1956; Helman, 1959)

\footnotetext{
${ }^{78}$ Minkowski, E. (1965). Recueil d'articles 1923-1965. In: Eugène Minkowski et Zéna Helman (Orgs.). Cahiers du groupe Françoise Minkowska. $\mathrm{n}^{\circ} 15$.

${ }^{79}$ Helman, Z. (1983). La vision en images dans la psychopathologie structurale. Bulletin dePsychologie, v. XXXVI, n. 362, p. 811-819.

${ }^{80}$ Helman, Z. (1998). Psychopathologie phénoméno-structurale et méthode de Rorschach: l'évolution d'un courant, ses développements actuels. Bulletin de Psychologie, v. 51,n. 434, p. 93-99.

${ }^{81}$ Minkowski, E. (1999). Traité de Psychopathologie. Paris: P.U.F. (Trabalho original publicado em 1966).
} 
Concordo com Barthélémy ${ }^{82}$ (2009) que afirma que a psicopatologia guarda uma coesão e coerência internas surpreendentes ao mesmo tempo em que todo ser humano tem capacidades inatas de adaptação. O foco clínico-investigativo vai de encontro à essência da pessoa e de como ela vive o sofrimento que a afeta (Barthélémy, 1997).

Pudemos verificar uma sensibilidade ao mundo dos afetos que vai sendo integrada por meio dos desenhos e do compartilhar as experiências em grupo. Dessa forma, a interrelação por meio da interlocução é central no método fenômenoestrutural no qual as evoluções são compreendidas pelo acesso à subjetividade compartilhada e a paciente pode seguir seu caminho para vir a ser quando alguém apreende aquele que se expressa (Ternoy ${ }^{83}$, 1987).

O ensinamento essencial que pude apreender ao longo de 13 anos trabalhando com Ateliê de Pintura de Livre Expressão é que cada desenho traz em si um segredo, que só pode ser revelado pela expressão verbal do criador. Cada participante é motivado a desenhar ou pintar algo. Podemos inferir qualquer comentário ou interpretação, mas sempre nos surpreendemos ao ouvir os pacientes. Nesse momento há um mistério revelado pela expressão verbal, que nos surpreende e nos ajuda a compreender o paciente a partir de seu idioma pessoal (Safra, 2006).

O caso apresentado mostra como uma paciente pode recuperar sua memória ao longo do tempo de modo absolutamente espontâneo e pessoal, como dizia Minkowska ${ }^{84}$ (1956) em relação ao que a linguagem dada ao Rorschach expressava. Ao encontrar interlocução para suas vivências, a paciente foi se surpreendendo quanto às reflexões que ela mesma fazia. O coordenador do grupo acompanhava atentamente

\footnotetext{
${ }^{82}$ Barthélémy, J.M. (2009). Comunicação pessoal. Curso de pós-graduação A psicopatologia fenômenoestrutural: aproximação teórica, clínica, psicopatológica e terapêutica; Programa de Pós-graduação do Departamento de Psicologia Clínica do Instituto de Psicologia da Universidade de São Paulo. http://www.iptv.usp.br:80/portal/Id.do?instance=0\&id=usp1FDbPYTI9BXmQUU0L8017MTaNSgrLjNpwnz VrrqeBWw.\&type=video

83 Ternoy, M. (1987). L'espace pictural de groupe. Rorschach et psychopathologie phénoménostructurale. Expression et psychopathologie. In Colloque Octobre. France: Recueil no. 3; pp.12-20.

${ }^{84}$ Minkowska F. (1956). Le Rorschach - à la recherche du monde des formes, France: Desclée de Brouwer; 1978.
} 
suas verbalizações e também dialogava com ela de modo ativo, expressando suas opiniões sobre o que ela mesma trazia, a cada momento em que se revelavam no encontro intersubjetivo.

\subsection{Os desenhos e as pinturas a partir de Michel Henry}

Acompanhando duas senhoras com vivências depressivas em ateliê de desenho livre pudemos observar na criação da imagem e na verbalização como a revelação verbal se modifica em uma paciente e em outra se mantém enigmática. Michel Henry em sua obra Ver o Invisível sobre Kandinsky afirma que a essência da arte é abstrata. 0 tema de uma obra não é o que representa, mas é seu pathos, que pertence às cores e às formas. Não é possível nenhuma sensação de forma e cor que não se afete e se impressione a si mesma. A vida está presente na imagem segundo sua essência própria. Vemos o que é próprio da criação, seu estilo e sua estética. As pacientes nos mostram um mundo e representam sua vida invisível e suas tonalidades nos desenhos. Assim refletimos uma evolução e uma incógnita na depressão e compreendemos a depressão, sem causa, como um sentimento invisível.

Na sua obra Ver o Invisível, Henry ${ }^{85}$ (2008) se aprofunda na análise da pintura de Kandinsky que, segundo Martins ${ }^{86}$ (2010, p.70), serve os propósitos de Michel Henry pelo fato de suas leis, seu abstracionismo, abandonarem em absoluto a figuração na arte e remeterem à vida subjetiva. Em A essência da arte, Michel Henry mostra que nos interessamos mais pela vida que pelo mundo, e a propriedade extraordinária que a define: sentir-se a si mesma, experimentar-se a si mesma (Henry, 2008, p.142).

"O tema de uma obra não é o que representa, um dado objetivo, seja a natureza ou a vida, sejam acontecimentos ou sentimentos. O tema de uma obra é seu pathos, mas este pertence às cores e às formas, é o próprio pathos de cores e formas". (Henry, 2008, p.144).

\footnotetext{
${ }^{85}$ Henry, M. (2008). Ver lo invisible - Acerca de Kandinsky. Madrid: Ediciones Siruela.

${ }^{86}$ Martins, F. (2010). Presença portuguesa na redefinição da fenomenologia e filosofia, hoje. In: Martins, F; Pereira, A. Michel Henry: o que pode um corpo? Lisboa; Universidade Católica Editora. p.70
} 
De acordo com Henry (2008, p.145), a arte é um modo da vida e "a vida está presente na arte segundo sua essência própria" (...) "Qual é a essência da vida? Não somente a experiência de si, se não, como sua consequência imediata, o crescimento de si. Experimentar-se a si mesmo, ao modo da vida é chegar a si mesmo, entrar em possessão do próprio ser, crescer na gente mesmo, ser afetado por um 'plus' que é o 'plus de si mesmo' (..) é uma maneira de gozar de si, é o gozo. Por isso a vida é um movimento: o movimento eterno que implica o passo do Sofrimento à Alegria - na medida em que a experiência que a vida faz de si é um Sofrer primitivo - , esse sentimento de si que a entrega a si mesmo, no gozo e na embriaguez de si".

A arte para Henry é a realização desse movimento eterno, pois a vida não é um estado, senão que vem segundo o processo de sua incansável chegada a si, e por isso a arte é necessária. "A arte é o devir da vida, o modo em que esse devir se realiza" (Henry, 2008, p.145). É na perspectiva do devir que o paciente que desenha ou pinta pode vir a se realizar ao seu próprio modo.

Na clínica, a capacidade de desejar depende de um eu desenvolvido, mas a partir de Henry temos outra possibilidade de compreensão, que inclui o afeto, que não depende do desejo como efeito pois o desejo é ele mesmo integralmente afetivo, e em sua carne é já Sofrimento (Henry, 2008, p.146).

O ateliê tomado como modalidade de atendimento clínico em grupo intenta não produzir uma obra de arte, mas realizar e expressar um processo de criação. Em Henry (2008, p.147) “a arte aparece como realização da essência da vida". Assim, é pela imagem que buscamos a revelação da essência da vida daquele que acompanhamos.

Ao concordamos com Henry que o ser humano vive uma impossibilidade de não ser ele mesmo, "de separar-se de si, de colocar-se à distância, de escapar de si, a obrigação que se lhe impõe de ser o que é até o final e para sempre, de esgotar todas as suas possibilidades e viver", a arte aparece como a resposta aportada pela vida, pelas "exigências que se derivam de sua mesma natureza, as suas próprias prescrições, a sua Necessidade Interior" (Henry, p.147). Antes do desejo, é a necessidade que se revela. 
Toda imaginação usada pela paciente em seus desenhos tem em Henry uma compreensão interessante: "a imaginação é o próprio historial da subjetividade, a expansão de seu pathos, o movimento pelo qual cada sonoridade desperta em si mesma a outra, e logo a outra. Assim vão surgindo sucessivamente, para cumprir o processo de sua cultura, todas as potencialidades escondidas na alma humana, o tesouro de suas ideias inatas, o infinito de sua capacidade de sentir e acessar a felicidade" (Henry, 2008, p. 148).

Para Henry toda pintura é abstrata e mantém uma essência eterna. O tema essencial da arte e seu interesse verdadeiro é a vida. "No início toda arte é sagrada, sua única preocupação é o sobrenatural. Isto quer dizer justamente que se preocupa com a vida, não do visível, mas do invisível. Por que a vida é sagrada? Porque a vivemos em nós como o que não projetamos nem desejamos, como o que nos atravessa sem que sejamos sua causa; a nós, que não somos nem fazemos nada mais que ser impulsionados por Ela. Esta passividade em nós da vida a respeito de se é nossa subjetividade patética; o conteúdo invisível, abstrato, da arte eterna, da pintura" (Henry, $2008^{87}$, p.150).

São as qualidades sensíveis que Henry mostra que foi deixada de lado pela ciência moderna para só reter do mundo suas formas ideais "responsáveis do conhecimento geométrico e matemático, isto é, precisamente rigoroso, objetivo e científico" (Henry 2008, p.150). Assim se suprimiu a pintura, "cujos elementos são todos qualidades sensíveis. Ao mesmo tempo em que estas, é a vida - onde formas e cores encontram sua existência original em sensações - a que é eliminada" (p.150). Na pintura os pressupostos do cientificismo não cabem.

Na obra de Kandinsky há a crítica ao "realismo" e uma desconfiança a respeito da ciência. Para Henry (p.151) a pintura faz ver em um mundo: “o que representa não é já propriamente o mundo, é, explícita, deliberada, incansavelmente, a vida, a vida invisível. $E$, consequentemente, suas tonalidades: a força, a alegria, o amor, o perdão, a purificação, o dom; a afirmação da vida por ela mesma e contra a morte: a fé, a certeza, a confiança em si mesmo. E seus contrários, que existem em forma de afetos:

\footnotetext{
${ }^{87}$ Nossa tradução.
} 
o medo, a dúvida, a inveja, o tédio, o orgulho, a crueldade, o desamparo, a injúria, a gula, o sofrimento" (Henry, 2008, p.151). Certamente, afirma Henry, "não percebemos nenhum desses sentimentos diretamente e em si mesmo porque, igual que a vida que o habita e faz dele o que é, um sentimento é invisível".

Assim, os desenhos realizados no ateliê mostram "as determinações invisíveis da subjetividade as que funcionam de entrada como principais reitores da construção da obra" (Henry, 2008, p.152). As pinturas são abstratas e ele se pergunta "o que significa ver e o que é exatamente o que se vê? Ver quer dizer, segundo os princípios da abstração, experimentar o pathos da cor que se vê, ser a realidade desse pathos, ser a Vida" (Henry,2008,p.155)

Apreciamos os desenhos realizados no Ateliê, mas nos perguntamos parafraseando Michel Henry: “O que significa ver e o que é exatamente o que se vê? Poderíamos acrescentar: como se pode ver a vida, a vida, que é o invisível? Ver quer dizer, segundo os princípios da abstração, experimentar o pathos da cor que se vê, ser a realidade desse pathos, ser a Vida" (Henry, 2008, p.155).

\section{Capítulo 6: Acompanhamento terapêutico e afetividade}

O AT se originou nas práticas que visaram transformar o tratamento psiquiátrico, contribuindo com uma prática singular e fundamental. Essa modalidade de intervenção clínica não deve ser vista como secundária, pois é a prática que busca compreensão das necessidades da vida do paciente em seu ambiente.

O Acompanhamento Terapêutico (AT) é uma prática clínica herdeira do movimento antipsiquiátrico inglês, da psiquiatria democrática italiana e da psicoterapia institucional francesa. Surge no campo da Saúde Mental. É um modelo de intervenção que ocorre no cotidiano de uma pessoa e não nos espaços tradicionais de tratamento. Nas décadas de 60 e 70, no Brasil e na Argentina, muitos psicanalistas trabalharam em hospitais psiquiátricos e comunidades terapêuticas. Desta forma, criaram novas funções para os agentes de saúde mental denominadas atendentes psiquiátricos e em outros lugares, auxiliares psiquiátricos. As funções desses agentes foram os embriões daquilo que mais tarde foi denominado amigo qualificado e, 
posteriormente, acompanhante terapêutico. Isto ocorreu na medida em que o trabalho foi se dando mais no dia a dia do paciente deixando as instituições (Antúnez, Barretto \& Safra $\left.{ }^{88}, 2011\right)$.

O Acompanhamento Terapêutico nos leva a testemunhar a maneira como os problemas contemporâneos afetam os modos de subjetivação do ser humano. Foi necessário o surgimento de uma modalidade de trabalho que implicava ofertar ao paciente relação, lugar, mundo, para ajudá-lo a superar o seu adoecimento. O trabalho se inspira nas necessidades éticas fundamentais do ser humano. Nessa perspectiva, o adoecimento é visto não só como decorrente de dinâmicas intrapsíquicas, mas também como decorrente do mal estar no mundo social e cultural em que vivemos.

A investigação de Barretto $^{89}$ (1998) sobre a ética no acompanhamento terapêutico traz facetas significativas da intervenção nessa modalidade de trabalho. Ele fundamenta o AT como um campo do experienciar cuja técnica de intervenção é o manejo da situação. Para isso levasse em conta a necessidade do paciente, a sua história e a cultura na qual se insere, possibilitando-Ihe estar com o outro em uma relação viva e humana.

Quando Minkowski faz um relato da relação estabelecida com um paciente com esquizofrenia, nos apresenta seu mundo pessoal. Quem lê é afetado por seu texto e a partir dessa experiência pode vir a compreender aquele que escreve. Estamos diante da possibilidade de acessar o mundo de vida daquele que chega até nós, pelo modo como somos afetados pelo outro, pelo modo que ele é.

A disponibilidade para compreensão é inerente à condição humana e o ser humano tem necessidade de ser compreendido e reconhecido em sua singularidade. 0 lugar clínico é fundado em uma posição ética e hermenêutica (Safra ${ }^{90}, 2006$, p.134). Nessa perspectiva, nos interessa abordar uma situação descrita por Minkowski buscando acessar o seu modo de compreensão do caso para dialogar com um modo

\footnotetext{
88 Antúnez, Barretto, Safra (2011). Acompanhamento terapêutico: contribuições de Minkowski. In: Acompanhamento terapêutico: casos clínicos e teorias. São Paulo: Casa do Psicólogo ${ }^{\circledR}$.

${ }^{89}$ Barretto, K.D. (1998) Ética e técnica no Acompanhamento terapêutico. Andanças com Dom Quixote e Sancho Pança. São Paulo: Unimarco Editora.

${ }^{90}$ Safra, G.(2006). Hermenêutica na situação clínica. O desvelar da singularidade pelo idioma pessoal. São Paulo: Edições Sobornost.
} 
de se realizar a prática clínica em acompanhamento terapêutico, tomando Minkowski como paradigma.

Ele apresenta seu primeiro relato de uma compreensão fenomenológica em psicopatologia. Trata-se de um atendimento a um senhor de 66 anos de idade, que apresentava uma esquizofrenia melancólica. O que tornou este atendimento próximo ao Acompanhamento Terapêutico é que Minkowski acompanhou esse senhor durante dois meses, dia e noite, ininterruptamente. Esse atendimento fez com que Minkowski descobrisse de forma inusitada as diferenças das vivências de tempo entre ele e seu paciente.

$\mathrm{O}$ atendimento nos remete a um acompanhamento intensivo, vinte e quatro horas por dia. No registro empático atentamos a como o terapeuta acompanha o discurso do paciente, como realiza em seu campo imagético o que foi descrito, como se move em sua corporeidade permitindo a compreensão da subjetividade do outro, e como acolhe o outro e as necessidades dele.

A psicopatologia fenomenológica de Minkowski ${ }^{91}$ (1970) possibilita penetrar profundamente no sutil mecanismo da personalidade humana e explicar os fenômenos essenciais que compõe a vida. Seu interesse se dirigia ao fenômeno do tempo, para quem o tempo requer uma análise mais profunda das noções como as de simultaneidade, sucessão, duração de um acontecimento que se desenvolve, ou também, noções de coincidência, presente, passado, futuro; e por outra parte, fenômenos psíquicos estreitamente relacionados com a noção de tempo, como se apressar, esperar, recordar, desejar, querer.

Ele introduz a noção de ímpeto vital (élan vital) e pessoal, que orienta a vida em direção ao futuro e não se manifesta ao exterior por meio do movimento voluntário senão mediante a obra pessoal em todos os seus matizes; e tende também a um ideal. O Ímpeto pessoal, futuro, ação e ideal estão estreitamente ligados entre si na vida humana; o intelecto é o que distingue tais noções uma das outras para localizá-las em

\footnotetext{
${ }^{91}$ Minkowski,E. (1970). Estudio psicologico y analisis fenomenologico de un caso de melancolia esquizofrenica. In: Minkoski, E; Von Gebsattel, V.E ; Strauss, E.W. Antropologia de la alienación. Caracas, Venezuela: Monte Avila Editores. (Originalmente publicado em 1923).
} 
diferentes conceitos. O problema do tempo desemboca, assim, no estudo da estrutura da personalidade humana.

Assim descreve a experiência com o paciente: Um caso fortuito, antes bem, as vicissitudes da vida, me obrigou a passar dois meses à cabeceira de um doente. Estava constantemente, dia e noite, com ele. Segue (Minkowski, 1970, p.18): A ocasião de acompanhá-lo dia após dia, não em um instituto psiquiátrico nem em uma casa de saúde, senão em um ambiente ordinário. A maneira de resistir às solicitações que todos habitualmente cedemos, a faculdade de adaptar-se às exigências da vida cotidiana, a variedade dos sintomas e seus matizes particulares aparece muito mais nítida em tais condições. (...) não podemos conservar uma atitude médica 24 horas por dia; acabamos por atuar a respeito do doente igual que outras pessoas que o rodeiam. Compaixão, doçura, persuasão, impaciência e fúria se sucedem assim alternadamente. (...) É como se duas melodias radicalmente desarmônicas fossem executadas simultaneamente e se estabelecesse, além do mais, uma certa equivalência entre as notas de um e do outro.

Desde os primeiros dias de vida em comum com o paciente, algo atraiu a atenção de Minkowski. O doente declarava que a sua execução capital aconteceria na noite seguinte. O jovem médico angustiado, não podia dormir e permanecia desperto toda a noite; se consolava dizendo que no dia seguinte ele poderia comprovar o infundado de seus temores; mas a mesma cena se repetia nos dias seguintes. Depois de três ou quatro dias, o doente ainda não havia mudado sua atitude.

Minkowski (1970) percebeu que ele, diante dos fatos havia chegado a uma conclusão a respeito do futuro, enquanto o paciente os havia deixado transcorrer sem ter extraído nenhum ensinamento para seu futuro. E constata que tal propulsão em direção ao porvir faltava completamente nesse paciente. Safra (2006) assinala que é parte da condição humana posicionar no futuro um sentido que significa cada gesto no presente. O agora é transfigurado pelo fim (Telos), que se aloja no horizonte futuro.

No caso apresentado observamos que o paciente vivia o seu futuro como fechado. Desse modo, tendia a viver o seu presente no registro do Mesmo. Minkowski nos convida a considerar que a conduta do doente estaria determinada pelo fato de que o enfraquecimento do ímpeto até o amanhã não seria momentâneo, mas permanente. Compreende-se, que no gesto em direção ao futuro existe um elemento 
de expansão, por meio do qual transpassamos os limites de nosso eu, deixamos uma marca pessoal sobre o devir e criamos a obra que se separa de nós. Isto se relaciona a um sentimento positivo que acompanha toda ação cumprida e toda decisão tomada.

Sem essa possibilidade o paciente de Minkowski (1970, p.30) tem o seu cotidiano sem vida e sem sentido. Certa vez, disse: Olhe essas rosas, minha esposa teria achado lindas, mas para mim não são outras coisas senão que um monte de folhas, pétalas, espinhos e hastes.

A noção de tempo se reduziu à noção de sucessões de dias iguais e o universo ficou hostil. O paciente distanciou-se de toda comunhão de ação e de ideias com seus semelhantes e assim os nexos de suas ideias se romperam. Há nesse tipo de situação a perda do sentido de comunidade. Em casos assim a modalidade clínica denominada acompanhamento terapêutico torna-se fundamental, pois o clínico entra no campo de experiência do paciente possibilitando o reestabelecimento do campo comunitário, que devolve ao paciente o nexo entre os homens e entre as ideias. Oferta de lugar comunitário que pode vir a ser o ponto de partida para o gesto que constitui o porvir.

Parece-nos que o paciente de Minkowski não encontrou a experiência que tenha sido oferta do outro para que se constituísse a experiência de comunidade. Ele se disponibilizou para o paciente, no entanto, isso não garantiu que o paciente pudesse encontrar a confiança que possibilitasse um sentido de si mesmo aberto ao futuro. Podemos observar que Minkowski, em seu trabalho com o seu paciente, foi afetado no registro afetivo e empático. Neste último, Minkowski acompanha o discurso do paciente e realiza em seu campo imagético o que era descrito pela narrativa repetitiva do paciente. Minkowski se move em seu corpo-imagem, permitindo a compreensão da subjetividade do outro. O médico se depara com o aprisionamento do outro e com a repetição do dia a dia do paciente. Ambos, clínico e paciente, vivem uma só repetição na relação. No registro ontológico (Safra, 2006) o terapeuta e o paciente estabelecem um nós comunitário. Todo não acontecimento na vida de alguém, estanca seu percurso de vida. Minkowski tinha razão ao descrever o seu paciente como estando em uma prisão sem futuro. 
Faceta importante para o Acompanhamento Terapêutico é apresentado por Minkowski (1970, p.31): Minha companhia o ajuda em certa medida, porque sei o que ele sabe e isso Ihe permite falar abertamente comigo; se estive ausente, ele necessita comunicar-me os descobrimentos que fez durante minha ausência. Há um saber do paciente e do terapeuta acontecendo entre eles. Essa experiência permitiu a Minkowski adentrar mais do que o habitual em contato com o psiquismo do doente.

Essa experiência pode ser tomada como um paradigma do fazer clínico e ético do Acompanhamento Terapêutico, pois nos ensina a acolher o outro em sua singularidade, na dimensão temporal do acontecer humano, que abre a experiência do convívio como espaço de diagnóstico e de terapêutica. Pensamos que na releitura dos escritos de Minkowski temos elementos importantes para a reflexão sobre o adoecimento e a clínica na atualidade.

\subsection{Acompanhamento terapêutico à luz da fenomenologia da vida de Michel Henry}

Tenho estudado os afetos, a afetividade, os sentimentos ao longo de minha carreira profissional. Primeiro em minhas investigações com o método do psiquiatra e psicanalista suíço Hermann Rorschach ${ }^{92}$ com seu método das manchas de tinta, a sessão sobre os afetos, baseada em critérios estatísticos e qualitativos. Com o tempo percebi que não aguçaram ainda mais minhas inquietações.

A Vida permitiu que conhecesse Florinda Martins, por intermédio dos psicanalistas brasileiros Gilberto Safra e Karin Wondracek, e por meio deles, Michel Henry e seus estudos originais sobre a fenomenologia da Vida (FdV). O afeto é a essência da Vida. Surpreendi-me, encontrava algo que palpitava e palpita em meu coração, desde meus quatro anos de idade. Nunca havia pensado que na filosofia encontraria uma obra que fosse de encontro às minhas necessidades e meus interesses mais profundos.

Minha trajetória pessoal, iniciada na psicanálise (por meio da psicologia), se encontra hoje mais próxima à $\mathrm{FdV}$, como jamais antes ousaria pensar que pudesse

\footnotetext{
${ }^{92}$ Rorschach, H. (1947). Psychodiagnostic. PUF: Paris (Trabalho originalmente publicado em 1921).
} 
ocorrer. A primeira sensação que tive é que Michel Henry colocava em palavras o que eu apenas sentia no corpo, sem representação possível, sem representação mental, eu sinto no corpo a Vida.

Da psicoterapia me dirigi para o Acompanhamento terapêutico, a partir da necessidade de pacientes e profissionais da saúde. Toda perspectiva fenomenológica que me auxilia a refletir profundamente o que acontece na relação com meu paciente e ilumina determinados aspectos obscuros, me serve. Se eu sinto qualquer distância da prática que vivo na relação humana com alguém, a refuto. Isso não ocorreu com a relação que estabeleço com a FdV. Há algo tão complexo quanto o pensamento vivo de Michel Henry. Ele me aproxima da Vida tal como a sinto e a vivencio. Isso por si só, me faz investir no diálogo íntimo e possível entre a FdV e a Clínica.

Ao começar os estudos de Michel Henry e Florinda Martins é fato a dificuldade que o psicólogo percebe diante da linguagem filosófica e porque não dizer teórica, porém surpreendentemente Viva. Nós psicólogos temos pacientes a cuidar, é nossa subjetividade viva diante de outra subjetividade, na qual o nós é a intersubjetividade.

Mas há algo tão vivo nessa perspectiva que todo esforço é válido, útil para tornar a clínica ainda mais afetiva, dinâmica e viva. Afinal, nenhum ser humano pode ser reduzido a qualquer teoria, seja ela qual for, psicanalítica, psicológica ou filosófica mesmo a de Michel Henry. A obra de Henry possibilita-me aberturas a dimensões jamais antes pensadas, mas certamente, sentidas! Razão viva, razão sentida, razão afetiva.

O Acompanhamento terapêutico (AT) é uma atividade muito próxima ao médico de família, quem sabe ao clínico de família? O AT me ajuda a refletir e reposicionar a clínica em diversos pontos, talvez um dos mais importantes seja que nenhuma teoria dá conta da complexidade humana tal como ela é e se revela, em movimento e no cotidiano.

No Colóquio Internacional Michel Henry (2012), Florinda Martins ${ }^{93}$ afirmou que “não há afeto inconsciente, tenho sempre consciência de meus estados afetivos. Posso

\footnotetext{
${ }^{93}$ Comentários de Florinda Martins à conferência de Karin Wondracek em 19/04/2012, Centro de Estudos em Filosofia, Universidade Católica Portuguesa, Lisboa, Portugal. http://cefi.fch.lisboa.ucp.pt/destaques/coloquio-internacional-michel-henry.html
} 
não pensar, refletir, decidir, mas jamais deixar de sentir!" Henry recupera o humano na filosofia? Não sei, mas me parece que ele recupera o humano na Vida.

O 'Acompanhamento Terapêutico (AT)' é um tipo de atendimento psicológico a pacientes com problemas psiquiátricos e psicológicos que acontece em um ambiente distinto a uma sala de consultório particular ou de uma instituição de saúde. O atendimento psicológico acontece na rua, em um shopping center, em um parque, no ônibus ou no metrô ou mesmo na própria casa do paciente. O 'acompanhante terapêutico (at)' atende a pessoa acompanhada e também a sua família. Na cidade de São Paulo (37 milhões de habitantes pelos dados do IBGE - Instituto Brasileiro de Geografia e estatística), muitos psiquiatras e psicoterapeutas solicitam Acompanhamento Terapêutico aos seus pacientes, pois percebem que as técnicas clássicas não dão conta de uma série de dificuldades e sofrimentos atuais. Universidades particulares e públicas começam a incluir nos currículos de graduação em psicologia essa especialidade. Frente a esta realidade social e clínica surge a necessidade de se conhecer e fundamentar essa prática clínica (Antúnez ${ }^{94}, 2011$ ).

Tal prática é ainda bastante nova nos meios universitários e por isso deve ser investigada em seus fundamentos. Para tanto, realizamos com este artigo uma reflexão à luz de Michel Henry sobre o alcance e limites dessa prática, assim nos indagamos: quais são as possibilidades dessa modalidade clínica? Qual é o poder de seu alcance? O que pode o AT na contemporaneidade?

Quando psicólogos se dispõem a acompanhar pacientes nessa perspectiva do AT, as teorias psicológicas auxiliam a entenderas experiências vividas que acontecem no contato interpessoal. Nesse sentido, a experiência clínica no Acompanhamento Terapêutico desconstrói teorias psicológicas pré-concebidas e facilita entrar em contato com a intersubjetividade. Esta inclui a presença e o contato com os fatores ambientais, no espaço onde acontecem os problemas, os sofrimentos, as agonias e as violências humanas.

O acompanhante terapêutico (at) tem a possibilidade de participar durante certo tempo da vida do paciente. O at convive com ele, com sua família, em casa, em

\footnotetext{
${ }^{94}$ Antúnez, A.E.A. (2011). (Org.) Acompanhamento Terapêutico. Casos Clínicos e Teorias. São Paulo: Casa do Psicólogo.
} 
outro lugar qualquer, lá onde a vida acontece e, antes de ser contada e narrada, como ocorre em uma sala de atendimento, é vivida e sentida no campo da afetividade.

O campo da afetividade é caro a Michel Henry e o afeto é um conceito essencial na clínica do AT. Para Henry o afeto é a evidência da vida, lá onde ela acontece como doação de si na vida. Ao supor uma ipseidade do pathos, onde a afetividade se revela a si como um si, observamos que muitos pacientes vivem uma fenomenalidade dos impasses de uma vida impessoal, na qual o inconsciente é apenas uma das figuras do sofrimento humano.

Cada paciente tem em seu âmago, vontade de viver. No Acompanhamento Terapêutico a teoria não se impõe, mas sim a relação humana. Desse modo dá-se fora a priori do registro da representação. É a vida na sua singular manifestação de si, no seu pathos, que se revela. Florinda Martins afirma que "o inconsciente e a representação estão no fundo da própria ipseidade da vida afetiva" (Martins ${ }^{95}$, 2009, p.11). Assim, o acompanhante terapêutico acompanha a ipseidade da vida afetiva de pacientes que se isolam do mundo e de si.

Em "Recuperar o Humanismo", Martins ${ }^{96}$ (2002) mostra como é que a fenomenologia em Henry recupera os temas "pessoa" e "ipseidade" em sua faceta humana, ao denunciar as teorias cuja compreensão do "ser humano" perde a afecção primordial da vida, fixando-se em construções transcendentais distantes desta doação afetiva em si de si.

Compreender o Acompanhamento Terapêutico a partir daquilo que se revela em si, como afetividade pura, pode reposicionar a psicoterapia, tal como Michel Henry faz em relação às fenomenologias de Husserl e Heidegger e às fenomenologias da segunda geração. Na experiência vivida pode-se sentir e valorizar a singularidade do outro, sem necessariamente nomeá-lo ou interpretá-lo, mas contemplá-lo em sua complexidade como fenômeno estudado, sem restringi-lo a dimensão biológica ou

\footnotetext{
95 Martins, F. (2009). Apresentação. In: Henry, M. Genealogia da psicanálise - o começo perdido. Curitiba: UFPR. pp.09-33.

96 Martins, F. Recuperar o Humanismo - Para uma fenomenologia da alteridade em Michel Henry. Prefácio: Michel Henry. Principia, Publicações Universitárias e Científicas: Cascais, 2002.
} 
psíquica. O que aparece em primeiro plano é a experiência de estar com e sentir com, que revela aspectos fundamentais dos encontros (Safra, 2006).

Acompanhar alguém se torna terapêutico quando possibilita vivências relacionais que muitas vezes nunca foram sentidas na relação com alguém significativo, pois por vezes o acompanhado foi privado de cuidados e interesse por parte do outro. O AT acontece na intropatia, que é condição para uma ética clínica vivencial em sua origem e manifestação. Dessa forma, o Acompanhamento Terapêutico revela-se como base da ação clínica e busca uma terapia para o sofrimento humano, não apenas para a psique.

Não cogitamos qualquer cura no Acompanhamento Terapêutico, mas oferecemos uma ação humana de devoção e solidariedade ao outro a partir de encontros significativos que possam auxiliar o outro a se conhecer melhor e conviver em seu ambiente. Estar com alguém acompanhado de um sentir com pode oferecer ao outro um encontro consigo mesmo, para que venha a se apropriar de um saber, que lá está, a espera para se desenvolver. O acompanhante terapêutico se oferece para que o acompanhado encontre a si mesmo e se sinta real. Acreditamos que a partir desta perspectiva o paciente possa destinar sua vida de modo diferente como o que tem feito até então (Safra, 2006).

Com as concepções de Michel Henry sobre a afetividade, se abre um vasto campo em psicologia clínica para estudarmos o que é mais original nos fundamentos de um acontecer clínico, que é o encontro puramente afetivo. Tal encontro humano com nossa própria vida está na base de toda instância cognitiva e comportamental, mas antes acontece na corporeidade onde a afetividade se revela antes de qualquer outra manifestação, o que coloca o ser humano em contato com sua violência originária na passibilidade da fenomenologia da vida como desenvolve Rolf Khün ${ }^{97}$ (2010).

É com a fenomenologia da Vida que focalizamos a vida humana, pois ela nos dá acesso ao ser e à vida, percorre um caminho que abandona o universo das abstrações

\footnotetext{
97 Kühn, R. (2010). Ipseidade e práxis subjectiva - Abordagens fenomenológicas e antropológicas segundo o pensamento de Michel Henry. Edições Colibri: Lisboa.
} 
e aparências e o distanciamento de si. O corpo é a prova imediata das impressões do ser e da vida; e nesse corpo o acompanhante terapêutico recebe a revelação em si e na empatia nasce a intersubjetividade.

“Para Michel Henry, só na adesão à vida se pode acolher as dificuldades e transmutá-las em acréscimo e fruição de si: só na vida se dá essa passagem do sofrer em fruir, mas também do fruir em sofrer" (Martins, 2009, p.23). Em Henry, a possibilidade de atualizar a potencialidade na qual se é dado a si mesmo é condição de existência. É nesta possibilidade última, afirma Florinda Martins, que se enraíza também toda possibilidade terapêutica. O poder do AT estaria no campo de um testemunhar-intervindo, em meio à esperança de que um movimento seja possível nessa passagem da dor à fruição.

No Acompanhamento Terapêutico a atenção do acompanhante não só se dirige ao discurso verbal de seu paciente, mas principalmente ao seu modo de ser, às comunicações não verbais, ao desconhecido, ao diferente, ao semelhante, ao outro, ao indizível e ao mistério. $O$ interesse não recai em um problema específico de interesse para o terapeuta, mas sim a atenção se dirige a todo ser diante de nós, àquele que acompanhamos, mas que também nos acompanha. A atenção se dirige ao sentir do próprio acompanhante e do outro, sente-se o próprio sentimento. Interessa-nos tudo o que se revela no paciente durante a relação. De acordo com Martins (2009, p.25) "a vida revela-se como sofrimento, mas não é apenas sofrimento o que experenciamos na vida. Nela experenciamos alegrias, mais ou menos intensas, desejos".

Desse modo, o AT é um campo onde se pode acompanhar o sofrimento que palpita entre dois, mas também celebra as alegrias e motivações que surgem na relação, desmistificando assim que o terapeuta só atenta para a dor, mas também valoriza as alegrias inerente à Vida.

De acordo com Cardoso 98 (2010, p.9) "há fenômenos, como por exemplo a alegria e o sofrimento, que são radical e irredutivelmente invisíveis, já que eles se dão na esfera da imanência subjectiva: não se vêem, experimentam-se na relação imediata de si consigo". Nesse sentido, o acompanhante terapêutico tem a possibilidade de

\footnotetext{
98 Cardoso, A. (2010). Apresentação. In KÜHN, R. (2010). Ipseidade e Práxis Subjectiva. Abordagens fenomenológicas e antropológicas segundo o pensamento de Michel Henry. Lisboa: Edições Colibri.
} 
presenciar alegrias e sofrimentos na relação terapêutica e em um lugar e ambiente que o paciente vive e com-vive. A passagem efetiva de uma tonalidade de dor a prazer e vice-versa, é a raiz da fundação de todo ato clínico ou terapêutico. Por isso, o Acompanhamento Terapêutico testemunha e se relaciona com a auto afecção de si originária, na raiz da relação humana e do mundo dos afetos.

O sofrimento, a angústia, o desespero, a depressão e a dor são subjetivos. A dor é minha dor (Monte \& Antunes ${ }^{99}, 1994$ ), e pode ser companheira de alguém. É uma vivência de si mesmo, o que Michel Henry denomina de ipseidade, que coloca a fenomenologia da vida nos antípodas das denominadas crises do sujeito, já que não é uma questão de identidade que se vivencia; pelo contrário, o eu, como diz Henry, vivencia-se a si mesmo mais do que nunca no desespero ou na depressão. Acompanhar alguém é viver um co-pathos, que implica uma relação de si consigo e com a vida, é aquilo que Henry chama pathos originário: a relação originária do sofrer e do fluir. Para Martins (2009, p.27) "é nessa modalização originária da Vida do sofrer/fruir que está o fundamento de qualquer terapia". Assim, a fenomenologia da Vida se aproxima e nos ajuda a compreender a vida com, o estar com nossa vida em contato com a vida do outro. Henry ${ }^{100}$ (2003, p.155) afirma: "é em virtude dessa dialética paradoxal escondida nos arcanos da vida que, na presença das mais graves doenças que afectam não só o corpo mas a própria vida, uma terapia é sempre possível".

De acordo com Karin Wondracek (2010), a dádiva da vida é o fundamento comum e o suporte de toda relação humana. Já que todas as relações se tecem. 0 sofrimento não é um afeto causado por um acontecimento estranho a si, mas revela o modo originário de eu ser nesta situação concreta em que me encontro.

O Acompanhamento Terapêutico, tal como o romance $O$ filho do rei que faz uma crítica ao automatismo das psicoterapias (Martins, 2009), propõe mais que um olhar, mas uma ação clínica transcendental para além dos diagnósticos, como afirma Khun (2010, p.73): “todo olhar clínico enquanto olhar transcendental do médico ou

\footnotetext{
99 Monte, M; Antunes, A. (1984). De mais ninguém. Letra de música. CD Cor de rosa e carvão. Gravadora EMI.

100 Henry, M. (2003). Souffrance et Vie in Phénoménologie de la Vie, TI, Paris, PUF.
} 
terapeuta visa, por detrás das diagnoses ou operações, um ser único no seu sofrimento e na sua esperança, quer dizer, na sua verdade transcendental".

Assim, o Acompanhamento Terapêutico reposicionado a partir da fenomenologia da Vida permite "uma nova abordagem da realidade terapêutica a partir do próprio vivido fenomenológico, e não só a partir de uma teoria 'metapsicológica' prévia" (Khun, 2010, p.74).

Com intuito de estabelecer as bases indispensáveis para uma análise da práxis terapêutica Khun (2010, p.39) mostra uma "nova metodologia fenomenológica, compreendida como um saber prático da vida e dado por esta". O Acompanhamento Terapêutico também questiona e dialoga com outros saberes instituídos, como o saber psicanalítico e o saber psiquiátrico. Porém, o real interesse no Acompanhamento Terapêutico recai no saber que brota da relação humana com nosso acompanhado.

De acordo com Khun (idem): "Este saber refere-se - ou melhor constitui, a efectuação fenomenológica como um saber que se conhece a si mesmo praticamente na sua realização". O acompanhante terapêutico não sabe mais do que o próprio paciente. Khun (2010, p.70) afirma que "o que resta, assim, no plano da prática terapêutica cotidiana, não é, em definitivo, um saber técnico dos "métodos terapêuticos" ou "educativos", mas uma intropatia que obedece às leis vivas da troca afetiva real e cuja meta-genealogia Michel Henry narrou sob a forma fictícia no seu romance "O filho do rei", que constitui, a este respeito, ao mesmo tempo, um livro fenomenológico. Efetivamente, aquele que "educa" e que "cura" não sabe mais da Vida do que aquele que sofre" (grifo meu). De modo que na intropatia efetiva não cabe nenhuma dominação sobre outrem.

A clínica do Acompanhamento Terapêutico vai de encontro ao humano e não à técnica. Nesse sentido, ainda é possível trocar as necessidades afetivas segundo as suas modalizações interiores próprias. Com efeito, os outros lugares tradicionais de uma reciprocidade ou comunidades vivas, tais como a arte e a ética encontram-se no presente marginalizados, se não já destruídos (Khün, 2010).

Os limites do AT aparecem em situações de impasse. Não é raro encontrarmos ats acompanhando pessoas e sentindo que uma evolução está acontecendo, aparece 
nos diálogos, nas reflexões posteriores e também no seio da relação, quando um impasse aparece. Tal impasse por vezes são impostos pela própria família, que não compreendendo a importância desse procedimento terapêutico o finda com a brusca interrupção do "tratamento". Sabemos a partir da clínica, que o amadurecimento de um componente da família atinge de maneiras diretas ou indiretas os componentes familiares.

Certa vez realizei um AT a um jovem que pensava pela primeira vez em suicídio, a família se assustou e aceitou a recomendação da psiquiatra do trabalho de AT. O jovem não saia de casa, não mais estudava e não queria trabalhar, o isolamento já estava estabelecido. Para o pai, seu filho deveria namorar, estudar e trabalhar. O AT durou dois anos, duas vezes por semana. O rapaz estava mais motivado, aproveitando muito a relação com o terapeuta, quando o at foi surpreendido ao ouvir na secretária eletrônica de sua residência um recado do pai: "avaliei a situação e como após esse trabalho meu filho não voltou a namorar, estudar e trabalhar, eu resolvi tentar outro "tratamento". Nunca mais tive acesso ao jovem e sua família, o mesmo ocorreu com a psiquiatra. Aquelas evoluções não puderam ser compreendidas pelo pai do moço, ele queria mais, ele queria resultados práticos e óbvios, daquela forma, seu filho não era aceito. Anos mais tarde, encontro a psiquiatra que me conta que o paciente havia retornado aos seus cuidados, o motivo disso é que o rapaz - apesar de saber da competência do psiquiatra que o vinha acompanhando - entrou em confronto com os pais, solicitando que retornasse à antiga psiquiatra, alegando que esta era mais carinhosa, cuidadosa e afetiva. Pela primeira vez ele havia confrontado seus pais para alcançar algo próprio.

Em supervisão a um aluno da graduação em psicologia, o mesmo conta que acompanhava um adolescente com determinada síndrome genética. $O$ at foi convivendo com o rapaz e a relação se tornou bastante viva para ambas as partes. A mãe do menino não deixava que o mesmo saísse de casa, o medo dela é que ele fosse raptado. Qualquer gesto de autonomia do menino era rechaçado pela própria mãe. $O$ at começou a tentar dialogar isso com ela, mas não houve nenhuma recepção para essas reflexões. Não havia qualquer abertura da mãe para outras possibilidades que envolvessem a ameaça de que os riscos que pensava poderem ocorrer, se realizassem. 
A mãe parou o trabalho. Meses depois, o aluno se depara com o menino nos corredores da Universidade, se cumprimentam e o menino diz "tenho saudades de nossos encontros". Outro exemplo que marcas significativas foram tatuadas na alma desse menino, mesmo que a responsável por ela tenha retirado o mesmo da relação com o at.

Essas vinhetas clínicas mostram que o poder do AT pode esbarrar na incompreensão desse tipo de trabalho pelos pais ou responsáveis. Terapeutas e psiquiatras percebem a importância desse trabalho, mas nem sempre é possível demonstrar isso aos pais. São fatos que merecem ser minuciosamente estudados e investigados. O poder do AT talvez resida nas possibilidades e potencialidades que podem ser recuperadas ou em outros casos criadas e desenvolvidas.

No Acompanhamento Terapêutico há espaço para o sofrimento e também para a alegria, no momento em que aparecem inseridos na cultura, na família, no ambiente nos quais o paciente vive. O Acompanhamento Terapêutico não trata de tornar consciente algum material recalcado, mas saber das possibilidades de o sujeito poder aderir a si mesmo, às suas formas de Vida de modo potencializante, modalizando o sofrer em fluir (Martins, 2009).

Nessa faceta essencial da vida, acompanhar alguém restitui a vida nela mesma. Acompanhamos e somos acompanhados, companheiros que se acolhem e vivem o encontro humano da terapêutica da Vida. Segundo Safra ${ }^{101}$ (2004, p.147), "solidariedade e amizade significam um princípio ético fundamental, só possível quando estamos realmente humildes (voltados ao húmus-terra), situação que ocorre ao estarmos nus de qualquer onipotência. Então compreendemos que nossa biografia é diferente da de nosso paciente, mas somos companheiros de viagem pelas intempéries da existência. Posicionados desta forma, estaremos em comunidade de destino, condição fundamental para o nascer, para o caminhar pela vida e para o morrer de qualquer ser humano"

No Acompanhamento Terapêutico as ações humanas têm uma potencialidade de abertura para uma esperança possível. "Se as clínicas se tornarem lugares de tal

\footnotetext{
${ }^{101}$ Safra, G.(2004). A po-ética na clínica contemporânea. Aparecida/São Paulo: Idéias e Letras.
} 
cultura e donde nada de vivo é previamente excluído por decreto teórico e abstracto, pode-se efectivamente continuar a reconhecer aí a presença efectiva desta Vida" (Kuhn, 2010, p.71).

A reflexão sobre a dialética dos afetos proposta por Michel Henry e recuperada por Florinda Martins em seus cursos ministrados em 2010 e 2011 nas Faculdades EST, em conferência na USP em 2010 e no curso ${ }^{102}$ de pós-graduação ministrado na USP em 2012, mostra como se torna visível na clínica do AT os sentimentos que tomam conta das cenas e guiam as condutas clínicas dos ats, que revelam como intervém a partir do que sentem em sua corporeidade, em sua interioridade. A reflexão teórica posterior os auxilia a compreender o invisível, mas sentido na pele e no coração.

Assim, todo o complexo trabalho de Michel Henry sobre a afetividade como essência da fenomenalidade da Vida tem suas leis próprias, não reduzíveis às leis racionalista das ciências naturais e do pensamento que domina a cultura ocidental. 0 AT vem dar as mãos ao auto afetar-se na Vida, a auto afecção de si mesmo.

A concepção de homem em Michel Henry é de um ser encarnado na sua ipseidade. A Vida se revela na carne. Para o AT é importante a vivência fenomenológica em seu aparecer e como aparece, Florinda Martins (2012) apresentou no curso A fenomenologia da Vida em Michel Henry e as psicoterapias, a dialética dos afetos (e não dos egos) na qual os terapeutas podem se guiar. A afetividade tem suas próprias leis, não reduzíveis às leias da uma concepção representacional.

Assim, a fenomenologia da Vida abre possibilidades de compreendermos a dialética dos sentimentos no Acompanhamento Terapêutico (AT). Os ats sentem a presença do acompanhado, pois cada um é afetado de dentro de si e no contato com o outro. E do afeto somos Vida.

O movimento na dupla ação, acompanhante e acompanhado, não supõe apenas a mediação do pensamento. No sentir-se e no mover-se acontece a revelação da vida e penso que essa revelação poderá ter sentido se testemunhada por alguém significativo. $O$ at não joga com as palavras do acompanhado, mas faz uma

\footnotetext{
${ }^{102}$ Curso de Pós-Graduação: Fenomenologia da Vida de Michel Henry e as psicoterapias. Programa de Pós-graduação em psicologia Clínica. Apoio: Pró-Reitoria de Pós-graduação da USP.
} 
interlocução com a essência da Vida, a afetividade. Nesse sentido, não é na dialética dos egos do ponto de vista representacional ou verbal que acontece a relação terapêutica, pois a partir de Henry o ego é compreendido como um sentir-se a si mesmo ${ }^{103}$. A afetividade está no centro da vida humana, na essência de duas ipseidades. Acompanhamos o movimento da afetividade da própria vida relacional. Para que o acompanhado possa em algum momento transformar o sofrimento que 0 paralisa, bloqueia ou angustia, necessita do outro, para que o sentir-se a si mesmo seja reconhecido. É como afirmou Candida Teixeira ${ }^{104}$ para aderir a si mesmo é necessário o outro, as necessidades humanas não passam apenas pelo biológico, o ser humano tem sede e fome, não só de água e comida, mas de amor.

$\mathrm{Na}$ obra organizada sobre a prática e as teorias do Acompanhamento Terapêutico - AT - na cidade de São Paulo (Antúnez, A.E.A, 2011), observamos como o AT é uma modalidade clínica que se exerce fora de um consultório particular ou de uma instituição de saúde mental, mas trabalha com elas. Os acompanhantes terapêuticos - ats - são chamados por médicos psiquiatras, psicoterapeutas, psicanalistas, equipes de saúde mental para intervir em determinados casos, desde um isolamento social, crises psicóticas, crises de pânico, estresses pós-traumáticos, síndromes genéticas, envelhecimento etc.

Podemos verificar no desenvolvimento dos capítulos a importância da área da afetividade nos mesmos. Os estudos da fenomenalidade da Vida afetiva em Michel Henry nos mostra como é possível refletirmos profundamente esta prática do AT, buscando seus fundamentos. A relação humana se impõe e as reações corporais dos ats se revelam dados imprescindíveis, para compreender a alteridade, via vivência clínica na intersubjetividade. Seguem comentários dos capítulos, deixando que se expressem por si mesmos.

É na obra de Eugène Minkowski, psicopatólogo russo-polonês que Antúnez, Barretto e Safra fazem uma compreensão pautada na ética do encontro humano. A experiência de Minkowski é tomada como paradigma do fazer clínico e ético do AT,

\footnotetext{
${ }^{103}$ De acordo com conferência de Anne Devarieux no Colóquio Internacional Michel Henry, Lisboa, 2012.

${ }^{104}$ Mesa-redonda no Colóquio Internacional Michel Henry, Lisboa, 2012.
} 
pois nos ensina como acolher o outro em sua singularidade, assinalando a dimensão temporal como elemento fundamental do acontecer humano. De modo a abrir uma experiência de convívio como espaço de diagnóstico e de terapêutica. Minkowski acompanhou durante dois meses, dia e noite, um paciente com esquizofrenia melancólica. Essa experiência mostra um modo de ser do paciente que o aprisiona em si mesmo, poder do sentimento; e o sentimento de poder do psiquiatra, que vê seu futuro aberto, enquanto o paciente, fechado em si. Não podemos escapar a nós mesmos. Tal sofrimento humano mostra que nenhuma terapia é possível, tal como Henry escreve no Romance $O$ Filho do Rei.

Carla Gonçalves expõe como escreveu um livro artesanal sobre a vida de uma paciente a partir da relação que estabelecia com ela. O psicanalista Mauricio Porto desenvolve um texto sobre o biopoder e o AT. O autor mostra como o at acolhe $a$ dimensão trágica da vida e do vivo, sem desencanto nem desamparo (p.53).

Oliveira \& Tufolo mostram um AT que durou dezesseis anos, a um paciente de quarenta anos que tinha um histórico sofrido desde os vinte anos, que incluía desistência de estudos universitários em economia, perda do pai e uso de drogas. O at expõe: Percebo que a minha presença era fundamental diante do que ele vivia e sentia, reconhecendo a existência de um ser humano com toda sua dignidade (p.62); só a experiência própria de uma vivência verdadeira pode colocar o terapeuta em ressonância com o outro (p.63). O homem como um ser vivo pleno de possibilidades $e$ sentimentos (p.63). Esse trabalho mostrou que o paciente não foi mais internado e a vida mostrou que ele pode ser (p.64).

Baptista tece considerações sobre as especificidades do AT no envelhecimento com uma senhora de 85 anos, de descendência italiana, que não mais se reconhecia, perdeu a mobilidade, tinha medo e não se senta feliz. Frequentaram aulas de pintura em cerâmica e sentia sua vida melhor (p.78). Com o AT seu cotidiano se transformou, sentia-se melhor, fez novas amizades. Transformação de sofrer em fruir!

Bezerra mostra a importância do trabalho em equipe do at em uma reflexão psicanalítica, desde Freud a Lacan e Winnicott, sempre aproveitando o que cada um 
desses psicanalistas a ajudava a compreender algo que via e sentia nessa prática clínica.

Logatti acompanhou Rita, analfabeta de 62 anos que apresentava comportamentos infantilizados, com pais falecidos e uma irmã. A at chega a conclusão que não é, portanto, pela via da razão que caminha a linguagem do AT e de outras formas de intervenção terapêutica (p.106), mas sim pela via da linguagem da poiesis (..) tanto na terapia quanto nas piadas, nos poemas e nos contos, a compreensão ocorre de forma natural, sem a necessidade de uma explicação racional (p.106). Na compreensão, não tentamos tomar posse do sentido e permanecer com ele para sempre, pois o sentido se desvela e se encobre. A explicação caminha somente na via intelectual, e cobra um sentido claro e fixo (p.107).

Fujihira expõe o trabalho do at com a deficiência de síndrome de Down, como experiência de pessoas que almejam a visibilidade, em um mundo que tende a não querer vê-las! Com eles acompanha as suas curiosidades sexuais, o interesse pelo namoro. A at levou um rapaz e uma moça a um congresso brasileiro sobre prevenção de doenças sexualmente transmissíveis. A autora considera que a clínica do AT, além de intervir num registro funcional (secretariando, interpretando e traduzindo a ambivalência), atua num registro existencial (ontológico), pois possibilita a experiência de vivenciar e reconhecer novas facetas do si mesmo em meio humano (p.118). A at acompanhou esses jovens a participarem de um evento e serem respeitados como pessoas, não excluídos, e conclui toda vez que voltamos de eventos assim, desembarcamos com uma bagagem bem maior do que havíamos levado: encontros vividos que tem marcado a vida de muitos! revelando que esses encontros também modificam o at.

Telles de Deus desenvolve aspectos do manejo na análise e AT a uma paciente psicótica de 28 anos. Piné também mostra que na proximidade do encontro, o AT corre os riscos dos impasses na experiência clínica. Não podemos deixar de reconhecer que tanto o acompanhante quanto o analista "sentem" nas sessões, e essa proximidade no encontro, como uma das dimensões do enquadre, é extremamente valiosa para a condução do tratamento (p.148). 
Vidal e Barretto o conto "Sorôco, sua mãe, sua filha" de Guimarães Rosa. O conto parece nos mostrar que não é a loucura que significa a não vida. A dor terrível é aquela que se faz na solidão. A dor sem a companhia do outro atinge o abismo da agonia. O canto dos outros abraça a nossa dor e a torna passível de ser sofrida. A loucura não exclui a condição humana fundamental de acompanhar e ser acompanhado; a possibilidade de estar com o Outro, de sentir com o Outro. (p.153). Assim, é fundamental a disponibilidade do acompanhante para o encontro e para os afetamentos que o acompanhado the causa. Esta disponibilidade, entretanto, ultrapassa os limites da clínica, e atinge a condição humana em qualquer situação, como é apresentado no conto de Guimarães Rosa (p.157).

Soares da Cruz discorre sobre a experiência de um AT que durou dois anos e meio a um rapaz que não era visto pelos pais! Muitas vezes, era difícil estar com ele, sobretudo em momentos nos quais os afetos eram indiscrimináveis, de medo sem ameaças, e longas meditações em silêncio profundo, de pedidos impossíveis de realizar (p.167). Tratava-se de um rapaz adotado e que não sabia dessa verdade. O at participou do momento dessa descoberta e da revolta do mesmo.

Della Torre mostra um AT a uma senhora e os diálogos com a poetisa Clarice Lispector. O AT surge para Lola como uma possibilidade de viver experiências com alguém. (..) não utilizei nenhuma técnica, mas isso não significava que eu estava desamparada. Eu estava amparada pela ética. A ética é reconhecer a pessoa em sua singularidade e necessidade e, a partir disso, exercer determinadas funções e ocupar posições que contribuam para o caminhar em direção ao devir (p.190).

De Marchi expõe um AT a pacientes psiquiátricos em um curso de Imagem e Fotografia fora do contexto hospitalar. Os pacientes ganharam em segurança, autonomia e melhora na autoestima, reconhecida por eles e por seus familiares.

Possani (p.210) revela os vários caminhos que pode andar um at e a condição empática do ser humano, onde a corporeidade foi ponte. O que se falou, o que se elaborou e o que se integrou deu-se a partir da comunicação empática. E a empatia, aqui, revela-se como acontecimento intersubjetivo. A empatia não ocorre em mim apenas. Quando a comunicação abriga a dimensão empática, ela se apresenta com 
aspectos dos dois seres, dos dois corpos que se comunicam. Não é um fenômeno unilateral. Há dois corpos que se empatizam, mesmo que apenas um seja cuidado (o que é falso, pois os dois são). Conta que ao longo de seu percurso como at, ela compreendeu que "é tarefa do at articular conceitos como corpo, corporeidade, empatia e estética para um posicionamento ético nos atendimentos (p.215).

Na apresentação, Chauí-Berlink comenta que são relatados nesse livro casos que nos emocionam e nos permitem compreender de uma maneira menos racional o fazer e a importância do AT. Somos, por assim dizer, pegos pelo coração. (...) O livro nos dá uma real noção da amplitude de ações de um at, a variedade de casos que podem ser atendidos por esse tipo de atividade e os vários referenciais em que cada acompanhante, em sua singularidade, se baseia para pensar e agir em seu fazer.

Esse livro traz amplas possibilidades de ser usado em uma reflexão da dialética dos afetos proposta por Michel Henry e recuperada por Florinda Martins. Fica visível que na clínica do $A T$ os sentimentos tomam conta das cenas e guiam as condutas clínicas dos ats, que revelam como intervém a partir do que sentem em sua corporeidade, em sua interioridade. A reflexão teórica posterior os auxilia a compreender o invisível, sempre sentido na pele e no coração.

Assim, todo o complexo trabalho de Michel Henry sobre a afetividade como essência da fenomenalidade da Vida tem suas leis próprias, não reduzíveis às leis racionalista das ciências naturais e do pensamento que domina a cultura ocidental. 0 AT vem dar as mãos ao auto afetar-se na Vida, a auto afecção de si mesmo.

A concepção de homem em Michel Henry é de um ser encarnado na sua ipseidade. A Vida se revela na carne. Para o AT é importante a vivência fenomenológica em seu aparecer e como aparece. Na dialética dos afetos os terapeutas podem se guiar. Assim, a fenomenologia da Vida abre possibilidades de compreendermos a dialética dos sentimentos no Acompanhamento Terapêutico (AT). Os ats sentem a presença do acompanhado, pois cada um é afetado de dentro de si e no contato com o outro. E do afeto somos Vida. 
Capítulo 7: Psicoterapia e psicopatologia compreendida a partir dos estudos da empatia e da estrutura da pessoa humana e a psicologia em Edith Stein

Os estudos sobre a estrutura da personalidade humana e empatia têm ampliado a compreensão do paciente cuidado em psicoterapia em minha prática clínica, no ensino e na pesquisa. Esses estudos me convidaram a uma desconstrução da terapia do psíquico. A partir de Edith Stein encontrei uma humanologia, que se revela mais próxima à realidade do vivido, que os estudos em psicologia e psicanálise.

A pessoa humana compreendida em sua dimensão corporal, psíquica e espiritual traz uma contribuição possível à psicologia. O estudo sobre empatia reposiciona o modo de estar com o outro na clínica. Anterior à simpatia e antipatia, a empatia é um modo de conhecimento da vivência do outro e de si a partir do que acontece na intersubjetividade.

O mundo contemporâneo nos mostra dificuldades a enfrentar e toda pessoa tem um potencialidade inerente a desenvolver em determinadas situações. A partir dos estudos fenomenológicos de Edith Stein, o diagnóstico psicológico se volta à experiência vivida entre duas pessoas.

Nesse sentido, todo e qualquer sintoma passa a ser mero coadjuvante diante de como a doença afeta o homem. Edith Stein nos mostrou como é possível romper com os preconceitos de modo ético, a começar pela exposição de sua própria história, vida e obra, repleta de sofrimentos e aproximações entre o modo de ser judaico e o católico. A essência comum a esses distintos modos de ser se situa na humanidade. Pretendo nesta parte expor as contribuições de Stein para a psicologia clínica a partir do estudo do humano.

O rigor fenomenológico é útil ao processo psicoterápico, pois possibilita conhecer uma pessoa a partir de seu vértice pessoal e do sentido de sua existência. Aproximamo-nos do outro em suas potencialidades e recursos e também em seus prejuízos decorrentes da falta da vivência de experiências humanas significativas no cotidiano. 
A análise fenomenológica (Ales Bello ${ }^{105}, 2004$ ) assentada na situação clínica $\left(\right.$ Safra $\left.{ }^{106}, 2006\right)$ reposiciona a clínica psicoterapêutica e possibilita uma compreensão original aos distintos modos de estar e ser das pessoas. Muitos pacientes procuram encontrar no terapeuta uma testemunha para suas aflições ou um interlocutor para auxiliá-los a alcançar um sentido para seu existir. O objetivo de buscar por meio de um método o sentido das vivências de sofrimento é um trabalho que articula concepções filosóficas e psicológicas relacionadas à essência do existir.

Edmund Husserl elaborou e empregou pela primeira vez no tomo II de suas Investigações Lógicas o método fenomenológico. O princípio fundamental deste método é fixar a atenção nas coisas mesmas. Algumas premissas devem ser rigorosamente seguidas, tais como: não fazer interrogações teóricas sobre as coisas, não usar o que se tenha ouvido ou lido sobre o fenômeno a estudar, aproximar-se das coisas livre de preconceitos, para beber da intuição imediata (Stein ${ }^{107}$, 2007). Plenamente de acordo com Stein (2007), se queremos saber quem é o homem, teremos que nos colocar de modo mais vivo possível na situação em que experimentamos a existência humana, o que dela experimentamos em nós mesmos e em nossos encontros com outros homens.

O segundo princípio do método fenomenológico é dirigir-se ao essencial. Em toda ação humana existe uma intuição do que a coisa é por essência, e isto tem dois significados: o que a coisa é por seu ser próprio e o que é por sua essência universal. 0 ato que capta a essência é uma percepção espiritual, que Husserl denominou intuição. Intuição da essência singular e comunitária do ser humano (Stein, 2007).

Ao fixar a atenção nas coisas como elas são e como se apresentam permite ao método fenomenológico aproximar-se do essencial por meio da intuição ou percepção espiritual. Assim, na perspectiva fenomenológica, a concepção de homem é compreendida por meio da estrutura tripartida do ser humano em corpo, psique e

\footnotetext{
${ }^{105}$ Ales Bello, A. (2004). Fenomenologia e ciências humanas: psicologia, história e religião. Bauru, São Paulo: Edusc.

${ }^{106}$ Safra, G. (2006). Hermenêutica na situação clínica. O desvelar da singularidade pelo idioma pessoal. São Paulo: Edições Sobornost.

${ }^{107}$ Stein, E. (2007). La estructura de la personalidad humana. 1.ed. Madrid: estúdios y ensayos. BAC. Filosofia y Ciências.
} 
espírito. A corporeidade é o que nos dá a constituição do ser que nos localiza. O corpo faz referência ao objeto físico e ao espaço. O espaço vivido está na base de todos os conceitos de espaço, distinto do espaço geométrico e idealizado da física (Ales Bello, 2004).

O registro dos atos do corpo é um terceiro momento, que supera a interioridade e a exterioridade, e possibilita ter consciência das coisas. Pode-se controlar o corpo e a psique, porém esse registro do ato de controle não é de ordem psíquica ou corpórea, mas de ordem espiritual (Ales Bello, 2004).

Husserl usava a palavra espírito porque na filosofia que o antecedeu, o que não era corpo era considerado da ordem da alma. Ele analisava a alma em duas partes: (a) uma formada por atos de caráter psíquico, cujo representante é o impulso psíquico não desejado ou incontrolável. Não somos nós as origens desses impulsos, nem nós que os provocamos, mas os encontramos. Se sentirmos um grande rumor, todos terão medo, e o medo não vem desejado por nós, ele é uma reação e acontece, essa é a parte psíquica; (b) a outra parte é a que reflete, decide e avalia, e está ligada aos atos da compreensão, da decisão, da reflexão, do pensar, sendo denominada de espírito. Todo ser humano tem potencialmente essas três características, umas mais, outras menos desenvolvidas que outras (Ales Bello ${ }^{108}, 2006$ ).

Os sujeitos acontecem nesses três distintos graus de presença e realização das suas atividades (Ales Bello, 2006). Primeiro, há pessoas que alcançam alto grau de desenvolvimento da estrutura comum a todo ser humano, ou seja, uma plena atividade corpórea, psíquica e espiritual, e mostram serem sujeitos educados, corpórea, psíquica e espiritualmente. O segundo grau representa um baixo grau de desenvolvimento espiritual e traz dificuldade para refletir, avaliar, decidir e controlarse (é esta dimensão que interessa particularmente à psicologia, especificamente à terapia). O resultado é a dificuldade para controlar os impulsos e as emoções, típico de alguém pouco educado espiritualmente (são os casos dos mais variados sintomas psiquiátricos. Tais sintomas recebem classificações em forma de diagnósticos, como transtornos de personalidade, personalidade antissocial, delinquentes, impulsivos, ou

${ }^{108}$ Ales Bello, A.(2006). Introdução à fenomenologia. Bauru: Edusc. 
mesmo da nosografia psicanalítica tradicional, os casos-fronteiriços, borderlines ou casos-limite). E também há pessoas com impossibilidade de realizar plenamente a estrutura humana, são pessoas com pouca realização da estrutura comum, típica em estados de coma.

Assim, temos a dimensão do corpo que veicula os atos corpóreos, nos quais encontramos os instintos em geral, como a fome e a sede, comuns a todos os seres humanos; a segunda dimensão, composta pelos atos psíquicos, inclui as reações emocionais, os impulsos para beber e comer; e a terceira dimensão é composta pelos atos espirituais, que é constituída pelos atos de reflexão, tomada de decisão, avaliação e controle. Nesse sentido, pessoas que sofrem por apresentarem transtornos psiquiátricos ou problemas psicológicos de tal magnitude que impedem as mesmas de trabalhar, estudar ou mais profundamente de encontrar um sentido para vida parecem se aproximar da segunda dimensão, sendo a terceira uma conquista ainda não pensada, acontecida, e que se encontra em espera.

Segundo Ales Bello (2006) conhecemos essas três dimensões porque temos Consciência, conceito fundamental em fenomenologia. A Consciência não é um lugar físico, nem um lugar específico, nem é de caráter espiritual ou psíquico. A Consciência é um ponto de convergência das operações humanas, que nos permite dizer o que estamos dizendo ou fazer o que estamos fazendo. Somos conscientes da realidade corpórea, da atividade psíquica e de uma atividade espiritual e temos consciência de que registramos esses atos. A distinção destes atos ocorre intuitivamente.

Essa noção de Consciência ultrapassa as noções clássicas em psicologia, na qual a consciência convida - de modo automático -a adentrar no inconsciente da psicanálise. Por trás de todo ato consciente há um inconsciente reprimido, por trás do manifesto pulsa algo latente que tem que ser descoberto. É necessário todo um arcabouço teórico do funcionamento psíquico ou mental para explicar o Homem e para estar diante dele, com objetivos de tratamento. Já a fenomenologia pura permite que reconheçamos o Homem em toda sua magnitude, na compreensão do que se revela, sem necessidades de pré-conceitos, pré-julgamentos para estar 
verdadeiramente com ele, o Homem, tal como é, ou seja, inclassificável e em sua humanidade.

Todos os seres humanos têm potencialmente a mesma estrutura humana, embora não a ativem da mesma maneira e não tenham os mesmos conteúdos, seja do ponto de vista psíquico ou do ponto de vista espiritual. Assumindo essa hipótese, Ales Bello (2006) afirma que as dificuldades ocorrem porque existem diferenças. Cita exemplos, como o de pessoas que podem ouvir e outras não, e aquelas que podem ver e outras não.

Diante dessa concepção de homem, nós psicólogos, podemos conhecer a subjetividade de outro modo. De acordo com Ales Bello (2006) essa elucidação é importante para a Psicologia na aplicação clínica a cada pessoa, tomada singularmente. Isso significa que todo ser humano registra atos psíquicos, como os impulsos que movimentam o homem para fora ou para dentro de si e os psicólogos, com este saber, podem compreender algo que uma pessoa específica está vivendo.

Ales Bello (2006) indaga que no campo da Psicologia, Psiquiatria ou Psicopatologia, ao considerar a complexidade do ser humano, como corpóreo, psíquico e espiritual, é preciso se perguntar: o que é a psique? o questionamento é se a Psicologia, como área de estudo da psique pode ou não cobrir este vasto campo definido como espiritual. Arrisco-me a responder à autora: não. É por isso que a filosofia fenomenológica traz uma contribuição sui generis ao aproximar as distintas disciplinas, que tem em seu objeto de estudo, a psicologia.

Husserl denominou Einfühlung, entropatia ou empatia a possibilidade de proximidade do outro, uma intencionalidade e orientação que conduz a um eu alheio. A intersubjetividade torna a vida comunitária, apesar de cada um permanecer na sua singularidade. Todo ser humano tem a qualidade de perceber, mas o que percebe e como percebe é absolutamente pessoal e singular.

A contribuição fenomenológica na clínica psicológica é a reflexão das coisas físicas ou abstratas que se mostram e como se mostram. Atentar para a empatia é 
reconhecer que por meio dela podemos nos comunicar e receber a comunicação do outro, conhecer as vivências alheias por meio da empatia.

Cada ser humano é examinado pelas suas características pessoais, ainda que haja uma estrutura comum e universal a todos. O que interessa a Husserl é o sentido de existir, bem como o fato do ser humano ter facilidade para identificar sentidos para certas coisas e mais dificuldades para outras. Nem todas as coisas são imediatamente compreensíveis. Nesse sentido, quando uma pessoa está diante de nós, conseguimos acessar e compreender algumas de suas características, outras não (Ales Bello, 2006).

A primeira obra de Edith Stein que se publica é sua tese de doutorado "Sobre o problema da Empatia" (Zum Problem der Einfühlung, 1917), onde analisa, a luz de uma metodologia estritamente fenomenológica, o fenômeno da existência de sujeitos alheios à própria pessoa. Bem como o ato fundante que nos possibilita a percepção de uma existência pessoal distinta à própria. A empatia é definida dessa maneira como a participação efetiva e pelo comum emotiva de um sujeito humano em uma realidade alheia ao mesmo sujeito (Bejas \& Spitzlei ${ }^{109}, 1998$, p.13).

Edith Stein, desde muito pequena, enquanto sua mãe arrumava seus cabelos, lia livros de história. Ela se destacava na escola, porém sofria por que era chamada "a inteligente Edith". Isso a magoava. Ela comenta: "eu acreditava que queriam que tivesse orgulho da minha inteligência. Além disso, parecia-me que, nas entrelinhas, queriam dizer que eu era apenas inteligente; e eu sabia já desde os primeiros anos de vida que é muito mais importante ser bom do que ser inteligente" (Feldmann ${ }^{110}, 2001$, p.13).

Edith fez um curso de enfermagem e trabalhou em 1915 em um hospital militar de epidemias: eram quatro mil leitos para soldados do front dos Cárpatos, doentes de tifo, cólera e disenteria. Segundo Feldman (2001, p.23), "ao lidar com o pesado sofrimento humano, ela certamente aprendeu o que nenhum livro de filosofia e nenhuma discussão altamente intelectual puderam Ihe ensinar". Ela tinha 24 anos.

${ }^{109}$ Bejas, A.; Spitzlei, S.(1998). Introducción y notas. In: Stein, E. Los caminhos del silencio interior. Madrid: Editorial de Espiritualidad.

${ }^{110}$ Feldman, C. (2001). Edith Stein: Judia, atéia e monja. Tradução Eurides Avance de Souza. Bauru, São Paulo: Edusc. 
Porém esse hospital foi fechado e não conseguiu mais uma colocação em serviços de enfermagem.

No ano de 1916, Husserl aceita um convite para passar de Göttingen a Freiburg, e escolheu como assistente a aluna que evidenciava maiores talentos: Edith Stein. Husserl era de opinião de que o mundo exterior só poderia ser "intersubjetivo", ou seja, experimentado por vários indivíduos que iriam pôr-se de acordo quanto às suas percepções. A essa vivência ele chamou de "empatia", sem defini-la mais precisamente.

"Quando, por exemplo, um amigo procura-me", comenta Edith Stein, "e eu percebo sua amargura, isso é mais do que uma simples percepção exterior. A experiência torna-se consciência alheia e a vivência alheia manifesta-se repentinamente em minha própria vivência. Certamente, nunca um estado de espírito alheio, uma circunstância psíquica alheia me foi revelado de forma tão íntima, tão direta e tão original como minha própria vivência. E é possível experimentá-los porque são dados não apenas as próprias ideias ou impressões, como também as coisas (um pressuposto básico dos fenomenólogos)". E vai mais a fundo, ao afirmar o seguinte: "na medida em que considero como 'minha semelhante', uma vida espiritual alheia, aprendo também a observar a mim mesma como objeto, isto é, de um ponto de vista exterior a mim. Tais 'empatias', se relacionadas a mim mesma, podem ser um corretivo útil para escapar da possibilidade de engano que está presente na percepção interna. É possível que outro me 'julgue com maior precisão' do que eu mesma o faria e me revele com clareza para mim mesma. Ele nota, por exemplo, que estou procurando obter aplausos quando pratico uma boa ação a alguém, enquanto eu mesmo penso que o estou fazendo por pura compaixão. Dessa forma, a empatia e a percepção interna trabalham de mãos dadas, possibilitando que conheça a mim mesma" (Feldmann, 2001, p.35).

Edith sofria por causa do abismo existente entre as questões acadêmicas e as necessidades reais dos seres humanos. Feldman (2001, p.81) comenta: "Quem é capaz de aceitar a si próprio sem ilusões e com todas as fraquezas e incapacidades, é também capaz de tratar o próximo de forma caridosa e com um amor verdadeiro". 
É nesse espírito que nos posicionamos na clínica psicológica diante de nosso semelhante, não na caridade, mas na solidariedade, não na paixão, mas no amor e compaixão. Façamos uma breve reflexão a partir do estudo da entropatia (Stein ${ }^{111}$, 2005). Um paciente conta sobre determinada vivência de agonia, o terapeuta não pode sentir do mesmo modo a agonia que ele sente, mas presencia uma série de fenômenos que se configuram na corporeidade do terapeuta, mais especificamente na sua memória. O terapeuta não sente da mesma forma a agonia do paciente, mas ele tem um registro e um saber sobre o que é agonia, a partir de suas próprias experiências e conhecimentos. Neste momento o terapeuta tem uma intuição do que é a agonia. Assim, à medida que uma pessoa expressa sua história ao terapeuta, este poderá compreender a essência de sua agonia.

Nesta vertente que une fenomenologia e clínica, a agonia relatada a alguém é uma tentativa de encontrar um sentido para si. O assunto e os fenômenos imagéticos estão presentes nas vivências entre o terapeuta e o paciente durante o encontro, fazendo parte essencial do campo intersubjetivo. Como o terapeuta manejará a situação clínica, dependerá da relação que estabelecerá com a pessoa, no processo de continuidade e descontinuidade da condição humana.

Do mesmo modo, qual a essência da raiva? Uma repulsa, um ódio, um impulso, uma revolta? Vivências universais. Entretanto, para cada sujeito o conteúdo é singular. Como a agonia, a raiva, os vários sintomas são parecidos e comuns a muitos, os conteúdos não, pois são singulares. É isso que torna a clínica um espaço peculiar para que o sujeito possa se encontrar, refletido no olhar do outro, assim ele se sentirá Real (Safra $\left.^{112}, 1995\right)$.

O paciente que conta sua agonia passa a doar ao terapeuta parte de sua história, que passa a ser habitada na memória do terapeuta. Tal experiência ao ser relatada, não deve ser entendida como repetitiva ou estereotipada, mas deve ser acolhida como gesto genuíno à espera de significados ou sentidos. Mesmo em uma

\footnotetext{
${ }^{111}$ Stein, E. (2005). Escritos filosóficos. Etapa fenomenológica. Obras Completas II. Editorial Monte Carmelo, Madrid, 2005.

112 Safra,G.(1995). Momentos mutativos em psicanálise. São Paulo: Casa do Psicólogo.
} 
pessoa que sofre com determinada psicopatologia severa, o potencial humano para encontrar alguém que a ajude a percorrer as intempéries da existência humana (Safra, 2004) pode estar adormecido ou em espera, mesmo que nunca se realize.

Se o terapeuta nunca sentiu sintomas semelhantes não quer dizer que não possa acessar essas experiências humanas por meio dos relatos de seus pacientes. Esses relatos não tocam apenas a mente do terapeuta, mas o tocam em toda sua corporeidade. Cada paciente marca o terapeuta de modo único. O terapeuta nessa perspectiva não detém um saber que o paciente não tem. O saber entre eles é construído a cada sessão e daí aflora material clínico para ser dialogado. O terapeuta é um interlocutor que oferece continuidade e cuidado diante da complexidade humana que quer se expressar, arando terreno para o desenvolvimento da área espiritual.

Com o tempo, a paciência e a tolerância, os sintomas poderão ser transformados em companheiros dominados pelo eu, isso per si, seria a cura almejada de uma psique que passa a ser refletida e elaborada pela área espiritual. O paciente ganharia novas interpretações para os sinais que nascem em sua interioridade, mesmo que justificados como vindos do exterior.

Diante dessas premissas da escola filosófica realizamos uma articulação não só teórica, mas experiencial com a clínica terapêutica. Há mais de uma centena de psicólogos clínicos na cidade de São Paulo que trabalham no registro empático e ontológico do ser humano. Acreditamos que a experiência de vida oferta um Saber sobre a condição humana, por vezes, não reconhecida ou apropriada pelo paciente.

Gilberto Safra nos apresenta belíssimas contribuições nesta clínica e utiliza a obra de Edith Stein no contexto da psicologia clínica e psicanálise. A partir da Estrutura da pessoa humana (1933), Edith Stein denomina ciência ideográfica para abordar a singularidade do ser humano. Safra (2006, p.15-16) comenta: "Edith era bastante lúcida para a questão de que a antropologia inerente às diferentes teorias poderia vir a adoecer o ser humano, questão que tenho observado na situação clínica ao longo dos anos. Ela alerta para o fato de que cada perspectiva epistemológica propõe uma concepção antropológica que pode aviltar o modo de ser humano e, portanto, pode vir a adoecê-lo em seu ser. Edith foi testemunha e vítima do que ocorria na Europa com o 
crescimento do nazismo e, para ela, esse fenômeno acontecia, entre outras razões, sustentado pelo equívoco no modo de abordar o ser humano e o mundo".

Há pacientes que se sentem adoecidos pelas perspectivas racionalistas e iluministas que norteiam, segundo Safra (2006, p.16-17) "grande parte das teorias em psicologia e organizam o mundo em que vivemos". Ele cita uma passagem da obra $A$ estrutura da pessoa humana que indica um distinto modo de compreender o outro ser humano: "Se o conhecimento é uma captação espiritual de um ente, é lícito dizer que conhecemos o modo de ser próprio de um homem: este modo de ser nos mostra através de múltiplas formas expressivas nas quais o "interior" se "exterioriza" e nós compreendemos essa linguagem. O modo de ser próprio de uma pessoa se expressa em formas que podem seguir existindo separadas dela: em sua letra, no estilo que se reflete em suas cartas ou em outras manifestações literárias, em todas as suas obras, e também nos efeitos que produziram em outros homens".

É importante trabalharmos na intuição e na compreensão empática, não como funções mentais, mas como funções corporais, já que - segundo Safra (2006) - se intui e se empatiza por meio de nossa sensibilidade. Essa concepção é muito nova no campo psicológico e psicanalítico e difícil de ser assimilada por aqueles que estão acostumados a reproduzir o mesmo ou se posicionar em um lugar que thes parece melhor ou superior a outros a partir de um excesso de racionalidade, intelectualismo e um apego em demasia às teorias metapsicológicas.

No estudo sobre os problemas da empatia, Safra (2006, p.46) cometa que Edith Stein: "se propõe a fazer uma investigação fenomenológica do sentido de si, daquilo que se é como pessoa. Por meio desse caminho fenomenológico, Stein afirma que temos a memória de experiências que não vivemos diretamente. Ela mostra que há movimentos psíquicos, organizações de experiências alojadas em nós mesmos, que não realizamos por nós mesmos. Ou seja, há inúmeras experiências em nós mesmos que existem porque tivemos a possibilidade de acompanhar a experiência de uma outra pessoa. Edith nos oferece alguns exemplos: 'ao ouvir a descrição de uma cena repugnante vivida por alguém, podemos, pela forma como essa pessoa a descreve, viver uma experiência de repugnância que é fruto de um percurso em que nos 
deixamos levar, acompanhando o que esta pessoa nos apresenta a partir de sua sensibilidade' ". É aqui que ela fundamenta o fenômeno da empatia, afirma Safra (2006).

Esses estudos colocam a clínica em uma convivência que não só ajuda o outro, mas há um verdadeiro crescimento e amadurecimento do próprio terapeuta que se coloca em abertura para o novo, para o estranho, para o desconhecido, em processos terapêuticos que demandam aliança, ética, confiança, solidariedade, continuidade e estabilidade.

Essas questões são discutidas por Stein para mostrar que, por meio do corpo, estamos continuamente acompanhando as experiências de outras pessoas. Somos frequentemente banhados pelas descrições plásticas e pelo modo como a corporeidade do outro nos fala. É nesse fenômeno que Edith Stein fundamenta o fenômeno da empatia, bem diferente da compreensão meramente racionalizada ou excessivamente intelectualizada da vida humana. "Para essa autora a empatia é a possibilidade que temos de acompanhar o circuito da sensibilidade de um outro. Edith afirma que podemos acompanhar dois circuitos: o circuito da sensibilidade e o circuito da articulação do pensamento do outro. Jamais se alcança a experiência originária da sensibilidade do outro, assim como também jamais apreendemos pelo conhecimento quais seriam os motivos, os valores últimos de alguém. Podemos intuí-los, mas não saber desses valores diretamente. A possibilidade de acompanhar a expressão descritiva plástica ou o modo como a corporeidade do outro aparece permite que realizemos com o nosso próprio corpo o mesmo circuito descrito ou apresentado. Dessa maneira, podemos compreender os sentimentos dos nossos analisandos através do que nos apresentam, se também os acompanharmos por meio de nossa sensibilidade corporal. O nosso corpo nos fala por meio de imagens (a imagem referese a formas sensoriais que se desenham na corporeidade de uma pessoa) que são evocadas em nossa corporeidade pelo modo como o paciente se apresenta" (...) "o analista inclui o que se passa, não por telepatia, mas pelo fato de seu corpo estar sendo continuamente afetado pela forma de ser do paciente" (Safra, 2006, p.47-48). 
Trabalhamos diante da manifestação do Real, no que está para além de qualquer possibilidade de simbolização, e assim acolhemos o irrepresentável. De acordo com Safra (2006) o homem, sendo ontologicamente um ente em precariedade, está sempre aberto à compreensão do ser e busca responder às questões da sua origem e de seu fim.

A função do terapeuta é de auxiliar o outro na apropriação de seu saber. Para isso o terapeuta necessita colocar seus interesses pessoais à sombra (Safra ${ }^{113}, 2007$ ), para estar em abertura, solidariedade e disponibilidade para o outro, para que a experiência de nós possa ocorrer. A cada encontro há um desvelamento da memória do humano por meio da experiência de sentir com, de estar junto existencialmente. É assim que o sentido de toda experiência se abre ao outro (Safra, 2007).

O mundo contemporâneo tem sido marcado pelo imediato, pelo automatismo, pela técnica, e não pela experiência, não pelo sentimento. Diante dessa realidade o espírito humano se fragmenta. Esta perspectiva de trabalho terapêutico trata de um reposicionamento da clínica psicológica como elemento ético-ontológico que possibilita a dupla terapeuta-paciente se sentirem enraizados na experiência humana. O terapeuta acolhe o vivido, o vivo e principalmente, o anseio pelo devir ou seu impedimento, o Real e o mistério da existência humana.

Nesta abordagem terapêutica é fundamental o conceito de compreensão empática como forma de saber e de conhecer o outro, além do reconhecimento ético das necessidades do paciente, da atenção ao modo como o paciente guia o terapeuta para que este acesse aspectos essenciais de sua personalidade. Cada paciente tem um saber de suas experiências e é o processo terapêutico que visará que ele possa se apropriar deste saber, para poder alcançar o domínio do eu e de sua própria biografia, para colocar em marcha seu vir a ser (Safra ${ }^{114}$, 1999).

A psicoterapia situada no registro ético-ontológico poderá acolher a dor de seu paciente no registro de seu aparecimento, sustentar e compartilhar experiências

\footnotetext{
${ }^{113}$ Safra, G. (2007). Profoco. Curso de Formação Continuada. Abril, 2007. Transferência: o estar diante, o estar em, o estar com. São Paulo: Edições Sobornost, DVD1, 2, 3, 4.

${ }^{114}$ Safra, G.(1999). A face estética do Self. Teoria e Clínica. São Paulo: Unimarco Editora.
} 
vividas, revividas e aquelas do porvir, em revelação fenomenológica pura. Ao acompanhar terapeuticamente alguém não raras vezes percebemos que no início dos encontros as queixas sintomáticas são os principais assuntos, mas com o passar do tempo, da continuidade e da relação interpessoal, tais sintomas não mais se tornam o centro das atenções. A atenção vai se direcionando a outros campos de sua existência, de acordo com a singularidade do paciente e da vivência experimentada na interrelação.

Há pessoas que não alcançaram a possibilidade de sofrer, vivendo suspensas em um estado de agonia (Safra, 1999). Sofrer implica em devir, em destinar o vivido. Assim, a clínica que se norteia por esta vertente fenomenológica pura poderá auxiliar o paciente a alcançar a potencialidade de sua vida reflexiva, a responsabilidade e a liberdade, a tomar decisões mais adequadas e encontrar significados para seu viver em atos de realização consciente. Em outras palavras, a acessar e desenvolver sua dimensão espiritual.

Se a forma de se inscrever no mundo não pôde ser realizada pela comunicação com alguém significativo, certamente tenderá a acontecer de forma impulsiva e desorganizada, expressando o desespero sem nome, vivido pelas pessoas que não tiveram aqueles acontecimentos em suas vidas. Ao lidar com humanos, estamos diante de seres que buscam intensamente com os meios disponíveis, a possibilidade de humanizar-se (Safra, 1999). Assim, todo ser humano necessita acontecer no registro singular e coletivo, isso é fundamental na realização do si - mesmo. Na ausência de um desses registros, há um sofrimento pela vivência de não existência e de não realização de si.

Do ponto de vista fenomenológico, o terapeuta não se guia pelos sintomas, nem mesmo deseja que desapareçam, mas auxilia o paciente a encontrar um sentido para suas vivências, desde que se estabeleça um vínculo de confiança significativo. As vivências psicopatológicas têm para cada paciente um significado, mesmo que seus comportamentos sejam universalmente parecidos. O que interessa nesta vertente é como cada indivíduo vive a doença e/ou sofrimento que os afetam. Por vezes, esses sintomas, são sinais de alerta para que se possa iniciar uma relação humana, uma 
verdadeira interlocução baseada em uma relação ética que vise compreensão e reconhecimento, uma comunicação e convivência humana almejada.

Os pacientes que apresentam alguma psicopatologia ou intenso sofrimento emocional têm dificuldades em encontrar sentido para suas vivências. O ser humano que vive essas experiências com frequência busca alguém para ajudá-lo a enfrentar tal vivência que o assalta por dentro, mesmo que justifique como vindo de fora. Muitas pessoas apresentam um estreitamento da vivência passível de encontrar significado na existência, um aprisionamento em experiências que ainda não encontraram um sentido humano. Não há possibilidade de abertura, mas um aprisionamento em si mesmo. Não uma expectativa de devir, mas um congelamento, um bloqueio, uma barreira. Todo ser humano tenta elaborar as diversas situações e etapas da vida na presença de outrem, da sua comunidade e da sociedade na qual está inserido. Não acessar a dimensão espiritual leva o ser humano a impedimentos que estancam o uso da liberdade e do livre arbítrio.

Nessa reflexão fenomenológica e clínica concluo que os estudos fenomenológicos sobre a estrutura da pessoa humana e empatia de Edith Stein associados à clínica de Gilberto Safra tornam-se úteis e necessários para fundamentar uma clínica do cuidado, para além da psique, que permite mergulhar, parafraseando a escavação arqueológica, uma escavação humanológica. O percurso rumo à essência dos diversos modos de expressão humana, auxiliando os pacientes a descobrir e estimular os potenciais adormecidos de seu ser. No mundo contemporâneo, a partir dessas concepções já não cabe estudar a psique humana ou analisar a psique, mas torna-se necessário ir ao encontro de um estudo do humano, que possa unir não só o corpo, a psique, mas a antropologia, a filosofia, a psicologia, a psicanálise, a literatura, a arte, a pintura, a música e a poesia, numa verdadeira humanologia.

Que a estrutura da pessoa humana compreendida pela empatia volte a erguer a humanidade que no mundo contemporâneo sofre as consequências das próprias ações (des)humanas. O poema 115 "Assim é minha vida" é o fiel reflexo do terapeuta assentado no paradoxo humano e com ele me despeço: "Meus deveres caminham com

\footnotetext{
${ }^{115}$ http://www.fotolog.com.br/filo_10/30190010/ (Nossa tradução)
} 
meu canto / Sou e não sou: é esse meu destino. / Não sou se não acompanho as dores. / Dos que sofrem: são minhas dores. / Porque não posso ser sem ser de todos. / De todos os cavalos e oprimidos. / Venho do povo e canto para o povo: Minha poesia é cântico e castigo. / Me dizem: pertences à sombra. / Talvez, talvez, mas a luz caminho. / Sou o homem do pão e do peixe. / E não me encontrarão entre os livros, mas com as mulheres e os homens: eles têm me ensinado o infinito" (Pablo Neruda).

\subsection{A corporeidade em Stein}

A corporeidade na fenomenologia de Edith Stein é importante para a clínica por ser o próprio instrumento de auxílio psicológico, com todo repertório que temos. Ao discorrer sobre a corporeidade, Edith Stein divide o tema em duas partes. A primeira explora o corpo como uma coisa material (figura, constituição material, movimento e manifestações acústicas). Em seguida, discorre sobre o homem como organismo vivo (configuração desde dentro, movimento orgânico, a linha de separação entre o organismo e o animal, o processo vital para além do indivíduo e o vegetal do homem).

De acordo com Stein (2007), ao considerar o homem meramente em sua corporeidade ou como coisa material é considera-lo de modo abstrato, no qual prescindimos artificialmente de muitas coisas que pertencem ao fenômeno completo do homem: da vida, da alma e do espírito, que nos falam através de seu exterior. Essa consideração nos ajudará a compreender o homem em sua peculiaridade corporal. Pois o corpo é, como corpo, especificamente distinto de outros.

O homem tem uma estrutura que corresponde a uma figura determinada e fechada em si mesma. Cada homem é um exemplar de sua espécie, massa homogênea. O corpo humano tem essa peculiaridade, uma figura determinada, fechada em si mesma, indivisível, que se denomina individualidade.

A peculiaridade do ser humano em relação aos animais e vegetal leva Stein (2007, p. 40) a afirmar que "observamos sua característica, estrutura em membros, variada, simétrica e em conformidade com estritas leis". Para o homem é essencial a posição vertical e a nudez, como uma relativa falta de cobertura da figura básica e a relativa visibilidade da estrutura interna do corpo por meio da figura superficial. Essa legalidade da figura não é a de exemplares totalmente iguais de uma espécie, mas 
guarda uma menor ou maior proximidade a uma figura normal. E esta figura normal não é a mesma para toda espécie homem. Há diferenças na estrutura de um menino, de um jovem e de um adulto.

Sobre a constituição material, o conceito de órgão se orienta ao funcionamento das partes do corpo, da fisiologia. Há uma base morfológica no movimento e nas transformações do corpo e de suas partes. No movimento e na transformação se expressa a vida, a alma e o espírito. O corpo segue suas próprias leis. Dá como exemplo o tropeçar. Alguém tropeça e cai diante de um obstáculo ao seu movimento, que se impõe desde fora, mas tenta manter seu próprio movimento, diferente dos choques dos corpos meramente materiais.

A interrupção do movimento livre no espaço pode ocorrer quando algo se impõe fenomenalmente desde fora. Mas Stein alerta que também pode ser afetado desde dentro. O corpo como um todo tem suas leis próprias, como cada órgão. Exemplo: as mãos têm uma mobilidade especialmente alta e diferenciada. E discorre sobre o rosto, tão útil à clínica que coloca frente a frente, duas faces humanas: " $O$ rosto supera a todas as demais partes do corpo pela facilidade e multiplicidade de seus movimentos. Nele assistimos um movimento quase contínuo das partes, que muitas vezes não se fazem patente como tais partes, senão mais bem como modificações do todo. A estas se juntam outras modificações: mudança radical da cor do rosto, ou modificações deste mesmo e do tamanho ou do brilho dos olhos. Se a cabeça já por sua posição desempenha o papel preponderante no conjunto da estrutura do corpo humano, esta multiplicidade de possibilidades de mudança lhe presta ainda mais relevância" (Stein, 2007, p.42).

Até aqui tratamos do modo visível de manifestar-se o corpo humano. Agora nos aproximaremos das manifestações acústicas do mundo do corpo através dos demais sentidos. "Como base para a penetração espiritual das coisas, depois do visível vem o audível o que maior relevância possui" (Stein, E., p.43). Sons e ruídos, diferentemente da cor e da forma, nos comunicam algo de sua natureza material. O homem pode se fazer audível desde dentro. O material acústico é muito variado. Desde dentro o que interessa a Stein é que o corpo humano, igualmente que outros corpos, acontece por 
meio de um material sensorial muito variado. O corpo está mais além do dado puramente sensorial, pois o corpo humano percebe mais que um corpo meramente material. Seguindo as pistas que nos proporcionam as manifestações do corpo mesmo, Stein se volta ao homem como organismo vivo.

O homem como organismo vivo trata da configuração desde dentro, que leva o corpo a atravessar mudanças em sua configuração. Este configurar-se desde dentro é um peculiar modo de ser dos seres vivos. O processo de configuração tem um telos, ou seja, aponta para um fim. O fim é a estrutura plenamente configurada com todos os seus membros. Há diversos órgãos no organismo. $\mathrm{O}$ organismo vivo aponta para além de si mesmo. De modo que a percepção do mundo é matéria formalizada, a formalização é um processo vital. A forma é o que comunica existência. A força vital é finita. Com o tempo ocorre a decadência e a força diminui. A forma vital, a alma, faz do corpo humano um organismo. Quando nele não há vida, só é uma coisa material como outras muitas.

O movimento orgânico neste processo que denominamos vida é atividade e a atividade é movimento. Há movimentos internos e movimentos que vão de dentro para fora. Cada movimento tem suas leis próprias, de sua forma interna. Na medida em que a formalização ocorre, o corpo possui domínio sobre si mesmo. Mas nunca cessa de ser um corpo material e de estar submetido às condições do acontecer material.

A linha de separação entre o organismo e o animal faz do homem simultaneamente coisa, planta, animal e espírito, tudo isso de forma unitária. Stein (2007) alerta que falar de alma nos vegetais ou animais é designar um princípio vital interno e não que eles possuam a mesma alma que os homens.

O processo vital ou élan vital aponta para além do indivíduo, mas para a espécie. A unidade da espécie, não é meramente coletiva, mas genética. Que o indivíduo aponte à espécie não só tem o sentido de que se configura a si mesmo como exemplar da espécie, mas também desde si mesmo cria novos exemplares dela. 0 exemplo da flor mostra que ao abrir-se é a mais pura revelação, pois sai do estar fechada em si mesma, com caráter tranquilo e pacífico. 
O vegetal do homem mostra que o homem conserva das plantas 0 característico do corpo humano: a posição vertical. Como na flor, o rosto humano é revelação de si mesmo. O processo orgânico no qual o corpo vai se configurando tem seu paralelo no âmbito anímico-espiritual: o homem está inscrito em sua integridade em um processo de desenvolvimento. O homem e o animal estão abertos para dentro e para fora.

O vegetal no homem nem sempre se dá com a mesma intensidade. Comparece com mais pureza na criança que no adulto e no jovem. Para Stein (2997), não fazemos uma mera imagem poética quando gostamos de comparar as crianças com as flores: esta comparação tem um fundamento objetivo. Nas crianças encontramos um desgrudar-se e revelar-se ainda relativamente simples e ingênuos, como certo descansar em si mesmos. Por isso mesmo, ante elas temos a impressão do inocente, do pacífico e do desprendido de si mesmo. Há o especificamente vegetal, animal e o especificamente humano.

O tato, segundo Husserl, é o sentido por meio do qual registramos os confins do nosso corpo, que permite a orientação no espaço. O tato nos dá a sensação do nosso corpo e do corpo externo ao mesmo tempo. A conexão e a distinção entre nosso corpo e o corpo diverso. É através do registro dos atos do tato, da visão, da audição, do olfato, que podemos dizer que temos um corpo. Nós partimos dos atos e, através deles, chegamos à conclusão que existe um corpo em relação com o mundo externo. As coisas físicas são conhecidas através da corporeidade. Essa análise da corporeidade foi feita por Husserl em todo seu desenvolvimento. Trata-se da mesma análise que Merleau-Ponty faz em relação à corporeidade. Husserl conclui que podemos dizer que temos um corpo baseando-nos na análise dos atos registrados por nós, das sensações corpóreas que registramos (Ales Bello, 2006).

De acordo com Ales Bello (2006) o momento preliminar a tudo aquilo que nós fazemos é a corporeidade, pois nos dá a constituição do ser que nos localiza. No espaço vivido está a corporeidade e está em um espaço que permite o movimento, assim, evitamos obstáculos. Damo-nos conta de nossa corporeidade por que temos as 
vivências relativas às sensações corpóreas. Entre a interioridade e a exterioridade, há um terceiro elemento que é o registro dos atos, aquilo que possibilita ter consciência.

No meio psicanalítico, ao falar sobre a importância dos objetos e das coisas, Safra (2004) se refere à hilética descrita por Stein ${ }^{116}$ (2000). Toda coisa é passível de ser compreendida naquilo que veicula como possibilidade de estar no mundo, não só por uma apreensão fenomenologicamente hilética, mas pelo fato de que quem fez o objeto deixou nele certa maneira de estar no mundo, uma concepção de vida e um estilo de ser.

O termo hilética foi profundamente trabalhado por Stein (2000). Neste conceito, não usamos as coisas para criar uma metáfora, mas há nas coisas mesmas uma metáfora que se funda na experiência hilética. Seu exemplo mais claro é o granito, ele traz ao ser humano em seu registro hilético, a experiência de estabilidade e perenidade.

Nesse sentido, a corporeidade apreende o sentido e essência das coisas. Diante de um lago, é comum uma experiência de calmaria ou descanso, diante de um mar agitado, da força e perigo de sua grandeza. O mesmo ocorre diante de uma pessoa. Antes mesmo de sentarmos para dialogar, sentimos se a pessoa está bem ou mal, calma ou agitada, apreensiva ou feliz e assim por diante. O corpo fala antes da linguagem expressa verbalmente e nos revela muito do outro.

Safra (2006) se aprofunda em parte da obra de Edith Stein, encontrando ali preocupações semelhantes às dele, a de compreender a singularidade do outro pela hermenêutica de seu idioma pessoal. Como citamos anteriormente, a intuição e empatia passam a não ser compreendidas como funções mentais, mas funções corporais: intuímos e empatizamos através de nossa sensibilidade. "Por meio do corpo, estamos acompanhando continuamente as experiências de outras pessoas. Somos frequentemente banhados pelas descrições plásticas e pelo modo como a corporeidade do outro nos fala" (Safra, 2006, p.47).

\footnotetext{
${ }^{116}$ Stein, E. (2000). Philosophy of Psychology and humanities, Washington, D.D., ICS Publications. (In: Safra, 2006, A hermenêutica na situação clínica)
} 
De acordo com Safra (2006, p.48), "na situação clínica podemos acompanhar o discurso do analisando ao mesmo tempo em que somos afetados em nossa própria corporeidade pelo modo como o paciente organiza seu horizonte de vida. (...) $\mathrm{Na}$ atualidade o corpo, tal como é veiculado culturalmente, nos remete muito mais ao funcional do que ao existencial. Há um grande número de pacientes e analistas que estão desconectados de um corpo vivo. Se esta dimensão existencial não puder ser acolhida na análise, o corpo continuará sendo um instrumento funcional”.

Para Safra (2006) há dois elementos que podem ocasionar interferência no processo de comunicação com o paciente, por parte do analista. O primeiro é o analista que não tem o seu psiquismo alojado em seu corpo, ele pode acompanhar o discurso do paciente, mas não se deixar afetar pelas organizações plásticas que emergem na sessão. $O$ segundo, o analista pode se posicionar de modo defensivo, por uma crise de identidade que busca inserção social ou prestígio, em detrimento da pessoa que ele é, o que o leva a objetificar seu paciente e perder as possibilidades de comunicação subjetiva, longe da sensibilidade, próximo do distanciamento.

Portanto é importante não só pensarmos na corporeidade do outro, mas como vivemos e sentimos a nossa própria corporeidade, a corporeidade do terapeuta. Ao alojar o psiquismo em nosso corpo deixando-se afetar pelas organizações imagéticas que emergem do contato com o paciente e ao buscar a comunicação real e subjetiva na sensibilidade humana será possível revelar um saber que brota na relação humana.

A corporeidade compreendida como corpo ou coisa material e o homem como organismo vivo traz os alicerces dos estudos de Stein (2007) sobre a estrutura da pessoa humana, compreendida em sua forma tripartida: corporeidade, psique (emoções e impulsos) e espírito (capacidade de refletir, elaborar e tomar decisões). Tais estudos fenomenológicos são úteis às ciências humanas e a partir dessa compreensão fenomenológica é possível refletir e aprofundar os conhecimentos e experiências vividas na prática clínica. 


\subsection{Uma compreensão fenomenológica das desordens psiquiátricas ${ }^{117}$}

As vivências humanas de ansiedade, entre elas o pânico, a fobia, as obsessões podem se orientar pela reflexão fenomenológica sobre o ser humano e pela clínica assentada no registro ético e ontológico. O rigor fenomenológico é útil ao processo psicoterápico, pois possibilita conhecer uma pessoa a partir de seu vértice e idioma pessoal e do sentido, ou falta dele, dado às experiências humanas em seu cotidiano.

A análise fenomenológica e a ética-ontológica assentada na situação clínica reposicionam a clínica psicoterapêutica e possibilitam compreensões originais aos distintos modos de estar e ser das pessoas em psicoterapia. O paciente procura encontrar no psicoterapeuta uma testemunha para suas aflições e/ou um interlocutor para auxiliá-la a alcançar um sentido para seu existir.

Do ponto de vista de Edmund Husserl, o foco de estudo fenomenológico do ser humano é a essência do existir e não a existência em si mesma (Ales Bello, 2006). 0 objetivo de buscar por meio do método fenomenológico o sentido ou a essência da vivência de ansiedade é um trabalho que articula concepções filosóficas e psicológicas relacionadas à essência do existir.

A Ética é compreendida como o reconhecimento de si refletida pelo olhar e cuidado do Outro. A Ontologia é compreensão da condição humana, cuja visão de homem é a de um ser ontologicamente em precariedade, sempre aberto à compreensão, que busca responder às questões da sua origem e de seu fim (Safra, 2006).

O método clínico utilizado se orienta para além do psíquico, mas se dirige aos fenômenos imagéticos (Safra, 1999), à ética do encontro (Safra, 2004) e ao conhecimento do outro a partir de seu idioma pessoal (Safra, 2006). Nesta abordagem terapêutica é fundamental o conceito de compreensão como forma de saber e conhecer o outro, além do reconhecimento ético das necessidades do paciente, da

\footnotetext{
${ }^{117}$ Baseada na publicação: Antúnez, A.E.A. (2011). Ensaio para uma compreensão fenomenológica da vivência de pânico e fobia humana. In: Roberta Payá. (Org.). Intercâmbio das Psicoterapias - Como cada abordagem psicoterapêutica compreende os transtornos psiquiátricos. 1 ed. São Paulo: Roca, v. 1, p. 144-148.
} 
atenção ao modo como o paciente guia o terapeuta para que este acesse os núcleos de sua personalidade.

A intuição na clínica psicológica é a capacidade de apreender e compreender os símbolos que apresentam o modo de ser de alguém. Compreender alguém pelo registro ético-ontológico é procurar conhecimento que brota na relação, nos fenômenos imagéticos que o terapeuta cria espontaneamente diante do contato com o paciente e seus conteúdos. A intuição na clínica é tratada como um saber. Cada paciente tem um saber de suas experiências e é o processo terapêutico que visará que ele possa se apropriar do mesmo, para poder alcançar o domínio do eu e de sua própria biografia, colocando em marcha seu vir a ser.

Ao ter confiança e crença metodológica busca-se a verdade do paciente. Oferta-se o bem como ação que enriquece àquele que acompanhamos. O vínculo é marcado pela solidariedade diante do reconhecimento das agonias alheias, de modo que o espaço de experiência se transforma em lugar de cognição. Concordo com a afirmação de Safra (2004), que o viver humano não pode ser plenamente dito; entre o dizer e o indizível emerge a fala poética, na qual a palavra não se fecha, mas se abre para o não dito. Ater-se à técnica em primeiro lugar joga o paciente em direção ao conceituável, roubando-lhe o indizível e os mistérios de seu ser. Ele se torna homem coisa e não mais ser, não mais presença. É essa presença, sentida na continuidade de um processo psicoterápico que ampliará os potenciais adormecidos no âmago de cada ser.

A psicoterapia é uma atividade clínica que situada no registro ético-ontológico poderá acolher a dor de seu paciente no registro de seu aparecimento, sustentar e compartilhar experiências revividas, vividas e aquelas do porvir, em revelação fenomenológica pura. Aproximando-se assim, não de uma teoria que acolha o funcionamento mental paciente, mas do outro como ele é e vive seu sofrimento.

Frente a alguém ou a um poema apoiamos um pé na revelação e outro no não saber. Aceitar e tolerar o não saber é uma condição ética. Nesta, é fundamental estar posicionado no não saber para que a revelação da singularidade possa aparecer em algum momento do processo. Nesta clínica, o terapeuta está diante de seu paciente 
não só como um outro subjetivo, mas como Outro, que poderá estar representando para o paciente, seus ancestrais, seus descendentes, a humanidade, um representante da cultura (Safra, 2004). Há sempre um desespero vivido na expectativa de um encontro que transforme o insuportável em uma experiência que possa vir a ter um sentido, uma forma e possa vir a ser um sofrimento e não só uma dor, agonia ou aflição.

É preciso ter confiança no método empregado e no benefício do contato com esta realidade, a do contato interpessoal entre terapeuta e o sujeito. Ao acompanhar terapeuticamente alguém não raras vezes percebemos que no início dos encontros as queixas sintomáticas são os principais assuntos, mas com o passar do tempo, da continuidade e da relação interpessoal, tais sintomas não mais se tornam o centro das atenções. A atenção vai se direcionando a outros campos de sua existência, de acordo com a singularidade do paciente e da vivência experimentada na inter-relação, desde que de fato acompanhemos o paciente e não nossos interesses e desejos.

Em 1996 comecei a atender uma senhora que sofria de dores na língua sem causa orgânica verificável. Encaminhada por médicos especialistas em otorrinolaringologia aceitou fazer uma psicoterapia individual. Com os anos de atendimento, as dores desapareceram ou não faziam mais parte das preocupações da paciente. Vivi com ela - ao longo de dezesseis anos - encontros semanais, dois lutos e testemunhei a luta dela por sobreviver com o mínimo de harmonia em seu contexto familiar. A ansiedade que sentia a impulsionava a solicitar auxílio medicamentoso. Após ter tentando substituir a terapêutica medicamentosa por mais sessões semanais, acabei por acatar o pedido da paciente. Ela tinha o direito de procurar por si, mas ela pediu que eu intercedesse. Ela começou a usar ansiolíticos. No entanto admitiu, tanto quanto eu, seu próprio ritmo, pouco alterado pela contenção medicamentosa.

Essa senhora não alcançara a possibilidade de viver suspendendo seu estado diário de agonia. Sofrer implica em devir, em destinar o vivido. Assim, a fenomenologia e a clínica que se norteia por esta vertente poderá auxiliar o paciente a alcançar a potencialidade de sua vida reflexiva, a responsabilidade e a liberdade, a tomar 
decisões mais adequadas e encontrar significados para seu viver em atos de realização consciente.

Se a forma de se inscrever no mundo não pôde ser realizada pela comunicação com alguém significativo, certamente tenderá a acontecer de forma impulsiva e desorganizada, expressando o desespero sem nome, vivido pelas pessoas que não tiveram aqueles acontecimentos em suas vidas. Para lidar com humanos, estamos diante de seres que buscam intensamente, com os meios disponíveis, a possibilidade de humanizar-se (Safra, 1999). Assim, todo ser humano necessita acontecer no registro singular e coletivo, isso é fundamental na realização do si - mesmo. Na ausência de um desses registros, há um sofrimento pela vivência de não existência e de não realização de si.

Fenomenologicamente o terapeuta não se guia pelos sintomas, nem mesmo deseja que desapareçam, mas auxilia o paciente a encontrar um sentido para essas vivências, desde que se estabeleça um vínculo de confiança significativo. As vivências de ansiedade ou depressão têm para cada paciente um significado, mesmo que sejam universalmente parecidos os comportamentos. O que interessa nesta vertente é como cada indivíduo vive a doença que o afeta? Por vezes, esses sintomas, são sinais de alerta para que se possa iniciar uma relação humana, uma verdadeira interlocução baseada em uma relação ética que vise compreensão e reconhecimento, uma comunicação humana almejada.

Podemos ajudar os pacientes a entrar no espaço da pessoalidade. Para Safra (1999) percorrer os territórios do mundo com criatividade é um modo de desconstruir o mundo para torná-lo próprio. Já a impossibilidade de realizar este trabalho faz com que o espaço do mundo seja lugar de estranhamento, de angústia agorafóbica e de ansiedades paranoides. O encontro clínico nos mostra que no transtorno de pânico o indivíduo vive angústias de dispersão e aniquilação. O ser humano tem vivências de espaços fechados desde o aconchego à claustrofobia. Já o espaço aberto é vivido com sentimentos que variam entre a liberdade e a agorafobia. Os quadros somáticos, o pânico e a fobia demonstram a busca desesperada pela humanização de um corpo coisa, que ameaça com o não ser, com as ansiedades impensáveis. 
Os pacientes que apresentam pânico, fobias, obsessões, depressões têm dificuldades em encontrar sentido para suas vivências. A vivência de ansiedade se refere a uma experiência que o ser humano comunica não só com os sintomas corporais, mas antes de tudo, com um temor a ter um colapso, um medo diante da morte, de não conseguir dar continuidade à própria vida.

Já a vivência fóbica mostra um temor direcionado a certo objeto e desperta no ser humano uma ansiedade terrível. A fobia também está intimamente relacionada com a vivência espacial. Se diante de um lugar muito estreito, a ação impulsiva será a de fuga. Em lugar amplo, a busca desesperada por um lugar mais protegido. Se tais relatos são entendidos ou explicados em perspectiva outra que não aquela que o sujeito expressa em seu idioma pessoal, não será possível conhecer a essência do sujeito que vive o pânico ou a fobia de um modo singularizado (Safra, 1999).

O ser humano que vive essas experiências com frequência busca alguém para ajudá-lo a enfrentar tal vivência que o assalta por dentro. A pessoa que expressa o pânico e a pessoa que apresenta alguma fobia, tem um estreitamento da vivência passível de encontrar significado na existência, um aprisionamento em experiências que ainda não encontraram um sentido humano. Não há possibilidade de abertura, mas um aprisionamento em si mesmo.

Todo ser humano está voltado para seu próprio fim. O homem elabora as diversas situações e etapas da vida na presença de outro, da sua comunidade e da sociedade na qual está inserido. Tanto os sintomas de pânico quanto os fóbicos mostram impedimentos que estancam o uso da liberdade e do livre arbítrio, mas é a forma que encontram para lidar com as próprias vidas.

Mas afinal, o que é o pânico? Qual o sentido do pânico? A reflexão a partir do estudo da entropatia mostra, por exemplo, que um paciente, ao contar sobre suas vivências de pânico, o terapeuta não pode sentir do mesmo modo o pânico que ele sente, mas presencia uma série de fenômenos imagéticos que se configuram na corporeidade do terapeuta, mais especificamente na sua memória. Se o terapeuta não sente de fato o pânico de seu paciente, ele tem um registro e um saber sobre o que é pânico, a partir de suas próprias experiências ou conhecimentos; e mais que isso, sente 
a comunicação e a presença com seu paciente. Neste momento o terapeuta tem uma intuição do que é o pânico. Assim, à medida que uma pessoa expressa sua história ao terapeuta, permitirá a este compreender a essência de seu pânico. Trata-se de um modo de captar a vivência alheia em seu aspecto universal.

Nesta vertente fenomenológica e clínica, o pânico relatado a alguém é uma tentativa de encontrar um sentido para si. O assunto e os fenômenos imagéticos estão presentes nas vivências entre o terapeuta e o paciente durante a sessão, fazendo parte essencial do campo vincular. Como o terapeuta manejará a situação clinica, dependerá da relação que estabelecerá com a pessoa, no processo de continuidade e descontinuidade da condição humana.

Do mesmo modo, indaga-se: o que é a fobia? Qual a essência da fobia? Uma repulsa, um medo, um terror, um horror, vivências universais, entretanto para cada sujeito o conteúdo é singular. Como o pânico, as áreas sintomáticas são comuns a muitos, no entanto os conteúdos são singulares. É isso que torna a clínica um espaço potencial para que o sujeito possa se encontrar, refletido no olhar do outro.

O paciente que conta suas fobias passa a doar ao terapeuta parte de sua história, que passa a ser habitada na memória do terapeuta. Tal experiência ao ser relatada, não deve ser entendida como repetitiva ou estereotipada, mas deve ser acolhida como gesto genuíno à espera de significados. Salvo em quadros psicopatológicos severos, e mesmo nesses, o potencial humano para encontrar alguém que ajude a percorrer as intempéries da existência humana pode estar adormecido ou em espera, do que jamais de realizou.

Se o terapeuta nunca sentiu sintomas semelhantes não quer dizer que não possa acessar essas experiências humanas por meio dos relatos de seus pacientes. Esses relatos não tocam apenas a mente do terapeuta, mas o tocam em toda sua corporeidade. Cada paciente marca o terapeuta de modo único. O terapeuta nessa perspectiva não detém um saber que o paciente não tem. O saber entre eles é construído a cada sessão e daí aflora material clínico para ser trabalhado. O terapeuta é um interlocutor que oferece continuidade e cuidado diante da complexidade humana, arando terreno para o desenvolvimento da área espiritual. 
Assim, o pânico diante do medo de um colapso e o medo fóbico diante de algum objeto ou situação põe em risco o ser. Com o tempo, paciência e tolerância, os sintomas poderão ser transformados em companheiros dominados pelo eu, isso per si, seria a cura almejada de uma psique que passa a ser refletida e elaborada pela área espiritual. O paciente ganharia novas interpretações para os sinais que nascem em sua interioridade em contato com o exterior.

\section{Capítulo 8: Considerações finais}

O saber em psicologia acontece não só a partir de conceitos metapsicológicos ou representações teoréticas, mas também acontece na compreensão empática, na corporeidade, na carne. Em um segundo momento raciocinamos, refletimos, pensamos em. Os saberes vão se tecendo entre as práticas e as teorias psicanalíticas, psicopatológicas, psiquiátricas e fenomenológicas. Por essência a fenomenologia deixa pré-conceitos e pré-juízos para conhecer o que está diante de nós, auxiliando o terapeuta a conhecer o outro na intersubjetividade tal como ela se revela.

Desconstruímos saberes a todo o momento, ocorrem momentos mutativos ${ }^{118}$ não só na psicanálise, mas na Vida! Daí a grande desconstrução teórica, que ocorre em minha prática. Ao longo de duas décadas de estudo e atendimentos psicológicos fui descontruindo saberes, dialogando com certas fenomenologias. As contribuições fenomenológicas para a psicologia clínica foram essenciais em meu percurso, desde Eugène Minkowski, Françoise Minkowska e Zéna Helman na perspectiva fenômenoestrutural, que me trouxeram efetivamente uma contribuição sui generis em psicologia clínica, pouco conhecida em nosso país.

Com a filosofia fenomenológica de Edith Stein encontrei descrições profundas do ser humano, a partir da empatia e da noção da estrutura da pessoa humana. A visão fenomenológica de Edith Stein, Angela Ales Bello e Ir. Jacinta Turolo Garcia trazem novas possibilidades para fundamentar fenomenológica e antropologicamente as relações humanas, ao levarem em conta o universal e singular, o cuidado e a educação, os valores e a antropologia humana.

${ }^{118}$ Safra (1995). 
Essas vertentes diferem entre si aqui e acolá, mas em outros pontos se encontram. Como psicólogo clínico não me posiciono radicalmente por uma perspectiva ou por outra, como o filósofo em seu rigor de estudo do pensamento de cada autor. Mas sim, me interessa o que em cada um deles amplia uma faceta clínica nas modalidades de atendimento clínico apresentadas, ajudando-nos a compreender a complexidade de nossos pacientes.

Assim, na busca de um estudo do humano, que denomino humanologia, em psicologia clínica é para o humano que me dirijo, na tentativa de compreendê-lo e ajuda-lo em seu percurso. Aceitar, tolerar, ter paciência, contribui para reconhecer com coragem e esperança - a vulnerabilidade e a precariedade da Vida, assim como descrito por Safra ${ }^{119}$ (2006).

A alegria é Vida, a dor é vida, os fenômenos humanos são manifestações da Vida, do amor, do ódio e assim por diante. Auxiliar a transformar o sofrimento em fruição (Martins, 2011), é uma tarefa dos terapeutas que a fenomenologia da Vida de Michel Henry nos é útil, por se dirigir aos sentimentos e mais especificamente à afetividade como essência da Vida em alteridade.

Onde houver um ser humano interessado em estar com e sentir com (Safra ${ }^{120}$, 2007) o outro (e não só ouvi-lo e escutá-lo) poderá sempre auxiliar profundamente seu semelhante, é um ouvir-sentindo e agindo. Aí nasce um saber, fruto da relação e poderemos ofertar um lugar, não físico, mas no coração e na nossa interioridade, na hospitalidade humana o outro poderá se desenvolver e sair de um aprisionamento emocional.

Sentir com, pode soar a sentimentalismo, mas não o é. O terapeuta em estado de abertura e real interesse pelo outro, ao acompanhar seu paciente, o ajudará a que ele possa se conhecer melhor, com a ajuda dele mesmo. Acompanhamos o outro e também somos acompanhados, de modo que as potencialidades, do paciente e do terapeuta possam se revelar.

\footnotetext{
${ }^{119}$ Safra, G. (2006). A hermenêutica na situação clínica. O desvelar da singularidade pelo idioma pessoal. São Paulo: Edições Sobornost.

${ }^{120}$ Safra, G.(2007). Profoco - Programa de formação continuada. Transferência: o estar diante, o estar em, o estar com (DVD 1 a 4). São Paulo: Edições Sobornost.
} 
O terapeuta deve valorizar o saber que cada paciente traz em si, por vezes fruto do convívio íntimo e profundo com seu sofrimento. Todo terapeuta que se colocar em posição de possuir um saber que o paciente não tem, nesta perspectiva humanológica, não poderá compreender e acompanhar a evolução de alguém. Pois toda pessoa carrega em si uma semente a espera de se desenvolver, um potencial. Isso acontece quando a confiança se estabelece, mas nunca sabemos quando - e se de fato - ela aparecerá.

Devemos ajudar nossos pacientes a encontrarem - por eles mesmos - um modo de conviver com as suas próprias vidas, destinar seu viver, encontrar uma perspectiva futura, em meio ao pessimismo absoluto e depressivo, das ansiedades, impulsividades e da falta de sentido no mundo contemporâneo. O terapeuta posicionado em abertura trabalhará na compreensão empática.

Se tolerarmos os paradoxos da Vida é possível que possamos dar cada passo na Vida como se fosse o primeiro e último ao mesmo tempo. Se nas vivências depressivas o tempo do devir está fechado a alguém, ele deve estar aberto no terapeuta. É preciso paciência para compreender alguém. Só assim ofertaremos ao outro uma esperança e possibilidades. Paciência demanda tempo e no espaço vivido na hospitalidade do terapeuta, algo pode ser transformado.

O terapeuta pode ajudar o outro a encontrar um projeto existencial possível. Projeto que o ajude a encontrar sua vocação na Vida, que lhe dê reflexão, ânimo, vitalidade, dinamismo, moral e ética nas relações humanas. Seja no atendimento em grupo, no acompanhamento ou na psicoterapia, é a relação intersubjetiva que toma o plano principal, seja em movimento ou sentados, convivendo.

Onde o devir está fechado há uma possibilidade e potencialidade em espera. 0 contato humano atento, interessado e preocupado sempre deixa marcas, seja no atendimento dual, em grupo ou no acompanhamento terapêutico. Que as marcas sejam boas, para que o outro se alimente e siga seu percurso. Busca-se resgatar ou criar a liberdade de ação e expressão da afetividade, no encontro entre dois humanos. 
Eu posso oferecer o que falta ao outro ao acolher as expressões mais profundas de tristeza e dor, e assim acolhemos a dialética dos afetos na relação humana e não na dialética de egos, cujos interesses se dirigem ao discurso racional que deve ser decodificado em suas ideias.

Assim, concluo que a filosofia fenomenológica e a psicopatologia fenomenológica podem contribuir com muito rigor com novos fundamentos para essas modalidades de atuação do psicólogo clínico, seja na psicoterapia, no acompanhamento terapêutico e na psicopatologia, todas enriquecendo-se mutuamente.

Há ainda um longo percurso a investigar na clínica do ponto de vista fenomenológico. Cada uma dessas perspectivas é distinta entre si, mas o elo de ligação a meu ver é a vida humana representada pela afetividade.

De acordo com Ales Bello ao retornar às fontes da pesquisa fenomenológica podemos não só compreender o que constitui a fenomenologia, mas acima de tudo, redescobrir a estreita relação que os fenomenólogos clássicos, como Edmund Husserl em primeiro lugar - o fundador da escola, têm entre a pesquisa filosófica e a psicologia. "Se posso dizer que em certa medida - como eu tento dar a minha contribuição - a mesma fenomenologia nasce como resposta à solicitação provenientes da psicologia e da sua grande ambição - entre seus muitos propósitos teóricos - nasceu, e ainda tem sido e segue sendo, dar à pesquisa psicológica a informação necessária para estabelecer o seu próprio caminho. Certamente, a escolha é direcionada para uma psicologia qualitativa, que se pergunta o que é a psique e quais são os atos psíquicos, sem reduzi-los ao que é puramente quantitativo" (Angela Ales Bello ${ }^{121}, 2005$, p.14 $4^{122}$ ).

Assim meu percurso de dirige pelo destino humano cuidado no processo terapêutico, vibrando a cada fenômeno humano que acontece no cotidiano, sendo transformado por ele, estudando o humano, mais que a psique ou o intelecto. $\mathrm{Na}$ humanologia acolhe-se a compreensão como fonte de conhecimento muito próximo à

\footnotetext{
${ }^{121}$ Ales Bello, A. (2005). Le fonti fenomenologiche dela psicologia. Pisa: Edizione ETS.

${ }^{122}$ Nossa tradução.
} 
vivência do outro, se revelando ora pelo amor, ora pelo ódio. O equilíbrio só poderá chegar - e ele certamente espera por isso - com harmonia.

A psicoterapia deixa de ser uma terapia do psíquico, mas se dirige ao humano, no qual o psíquico é apenas uma dimensão. A psicopatologia deixa de ser cuidada em seus aspectos corporais e psíquicos, mas se abre a outra possibilidade, a partir do sofrimento de um semelhante, conhece-lo como por vezes ele anseia ser conhecido, via compreensão.

Propor uma humanologia em psicologia clínica é abrir-se para o que há de mais humano na Vida, a afetividade. Não é na vertente conceitual e representativa que se procura explicar o ser humano que sofre e busca o psicólogo clínico nesta humanologia, mas na vertente compreensiva, afetiva e humana. A humanologia permite pelo método fenomenológico chegar à essência na relação, ao pathos com, no estar e sentir com, nem à frente, nem atrás, ao lado. É com cuidado e rigor, que a Clínica resgata o humano de nosso paciente.

Certa vez perguntaram a Pablo Neruda: "Podría darnos una definición del Amor?" E ele responde: "Que ocurrencias! Y la definición del água o del vino para que sirven? El agua y el vino son para beberlos, lavar, regar, cantar, correr. El amor, sin definición, es para sentirlo, hacerlo, perderlo, recobrarlo, consumirlo, vivirlo, morirlo" (Neruda ${ }^{123}, 1970-$ E. 88).

Já Alberto Caeiro: "Creio no mundo como um malmequer, porque o vejo. Mas não penso nele, porque pensar é não compreender... O mundo não se fez para pensarmos nele (Pensar é estar doente dos olhos). Mas para olharmos para ele $e$ estarmos de acordo... Eu não tenho filosofia: tenho sentidos... Se falo na Natureza não é porque saiba o que ela é. Mas porque a amo, e amo-a por isso. Porque quem ama nunca sabe o que ama, nem sabe o que ama, nem o que é amar... Amar é a eterna inocência. E a única inocência não pensar" (Pessoa ${ }^{124}, 1980$, p.35).

\footnotetext{
${ }^{123}$ Neruda, P. (1970). In Bijit, R.S.(2004). Habla Neruda - Memorias imposibles de corregir, Santiago: Editorial Catalonia. p.84.

${ }^{124}$ Pessoa, F, 1888-1935. (1980) Ficções do interlúdio, 1: poemas completos de Alberto Caeiro. Rio de Janeiro: Nova Fronteira.
} 
Por fim, humanologia é estudar as manifestações do humano na clínica, reposicionando o lugar do afeto, da sensibilidade e do amor, é viver a relação intersubjetiva, experimentando-a, sentindo-a, perdendo-a, e vendo-a terminar. Compreender não só pelo pensamento e verbo, mas pelas comunicações silenciosas do corpo em movimento, que afeta e é afetado, somos afetos na vida (Martins, F, 2002). Compreensão via sensibilidade, sentidos, em uma postura investigativa que acolhe a ignorância, a inocência e a humildade, pois possibilita que o outro apareça e se expresse como sente que deve aparecer e buscar ser compreendido, para que possa seguir seu caminho, ajudando-o a retomar seu rumo, a seu modo. Os fenômenos vivos são iluminados na humanologia. O potencial humano está lá, só espera ser encontrado para se revelar.

\section{Referências bibliográficas}

Ales Bello, A. (2006). Introdução à fenomenologia. Tradução Ir. Jacinta Turolo Garcia e Miguel Mahfoud. Bauru: São Paulo: Edusc.

Ales Bello, A. (2005). Le fonti fenomenologiche dela psicologia. Pisa: Edizione ETS.

Ales Bello, A. (2004). Fenomenologia e ciências humanas: psicologia, história e religião. Bauru, São Paulo: Eusc, 2004.

Amorim, A. et al. (2001). Os outros em Eu. Porto 2001. Capital Européia da Cultura.

Antúnez, A.E.A; Barretto, K; Safra, G. (2011). Acompanhamento terapêutico: contribuições de Minkowski. In: Acompanhamento terapêutico: casos clínicos e teorias. São Paulo: Casa do Psicólogo Editora.

Antúnez, A.E.A. (2011). (Org.) Acompanhamento Terapêutico. Casos Clínicos e Teorias. São Paulo: Casa do Psicólogo Editora.

Allen, D.F. (2000). Apresentação. In: Minkowski, E. La esquizofrenia. México: Fondo de Cultura Económica (Originalmente publicado em 1927).

Audi, P. (2006). Michel Henry. Une trajectoire philosophique. Paris: Société d'édition Les Belles Lettres.

Barretto, K.D. (1998) Ética e técnica no Acompanhamento terapêutico. Andanças com Dom Quixote e Sancho Pança. São Paulo: Unimarco Editora. 
Barthélémy, J.M. (2009). Comunicação pessoal. Curso de pós-graduação: A psicopatologia fenômeno-estrutural: aproximação teórica, clínica, psicopatológica e terapêutica; Programa de Pós-graduação do Departamento de Psicologia Clínica do Instituto de Psicologia da Universidade de São Paulo. http://www.iptv.usp.br:80/portal/Id.do?instance=0\&id=usp1FDbPYTI9BXmQUU0L80I7 MTaNSgrLjNpwnzVrrqeBWw.\&type=video

Barthélémy, J. M. (2006). Importance et extension de l'approche qualitative dans la méthode phénoméno-structurale en psychopathologie. Bull. Soc. Sci. Méd. 2, 249-264.

Barthélémy, J.M. (1997). A análise da linguagem no Rorschach segundo o método fenômeno-estrutural. Anais - I Congresso da Sociedade Brasileira de Rorschach e outros Métodos Projetivos e I Congrès de la Société Internationale de Psychopathologie Phénoméno-structurale. Ribeirão Preto, 99-104. (trabalho completo)

Bejas, A.; Spitzlei, S.C. (1998). Introducción y notas. In: Stein, E. Los caminhos del silencio interior. Madrid: Editorial de Espiritualidad.

Binswanger, L. (1973). Artículos y Conferéncias Escojidas. Madrid: Gráficas Condor.

Cardoso, A. (2010). Apresentação. In KÜHN, R. Ipseidade e Práxis Subjectiva. Abordagens fenomenológicas e antropológicas segundo o pensamento de Michel Henry. Lisboa: Edições Colibri.

Feldman, C. (2001). Edith Stein: Judia, atéia e monja. Tradução Eurides Avance de Souza. Bauru, São Paulo: Edusc.

Fermín, F.J.S. (2000). In: Introdução geral. Stein, E, (2000). Obras Completas. Vol. I. Escritos autobiográficos y cartas. Madrid: Editorial Monte Carmelo.

Forghieri, Y. C. (2007). Aconselhamento terapêutico. Origens, fundamentos e prática. São Paulo: Thomson. Forghieri, Y. C. (2004). Psicologia Fenomenológica: fundamentos, método e pesquisa. São Paulo: Pioneira Thomson Learning.

Follin, S. (2000). Prólogo. In: Minkowski, E. La esquizofrenia. (2000). México: Fondo de Cultura Económica.

Granger, B. (2002). Présentation. In. Minkowski, E. Écrits Cliniques. Textes rassemblés par Bernard Granger. Ramonville Saint-Agne.

Helman, Z. (1998). Psychopathologie phénoméno-structurale et méthode de Rorschach: I'évolution d'un courant, ses développements actuels. Bulletin de Psychologie, v. 51,n. 434, p. 93-99.

Helman Z. (1997). Psicopatologia fenômeno-estrutural e método de rorschach: a evolução de uma corrente, seus desenvolvimentos atuais. Livro do I Congresso da sociedade Brasileira de Rorschach e outros Métodos Projetivos e I Congrès de La 
Société Internationale de psychopathologie Phénoméno-Structurale. Ribeirão preto: USP. Orgs, Jacquemin A et al. pp. 279-290.

Helman, Z. (1991). A evolução do Rorschach no contexto da psicopatologia fenomenológica-estrutural. Temas, São Paulo, 40/41,146-163.

Helman, Z. (1983). La vision en images dans la psychopathologie structurale. Bulletin dePsychologie, v. XXXVI, n. 362, p. 811-819.

Helman, Z. (1980). Structure et évolution dans lê courant de la psychopathologie structurale. Psychopathologie Structurale, 3.

Helman, Z. (1959). La pousée sensori-motrice. Bruxelles: Charles Dessart; 1971.

Henry, M. (2012). A Barbárie. São Paulo: É Realizações Editora. (Originalmente publicado em 1987).

Henry, M. (2010). As ciências e a Ética. Tradutor: Florinda Martins. Universidade de Beira Interior, Covilhã.

Henry, M. (2009). Genealogia da psicanálise - o começo perdido. Tradução e Notas: Rodrigo Vieira Marques; Apresentação: Florinda Martins. Editora UFPR: Curitiba, 2009.

Henry, M. (2008). Ver lo invisible - Acerca de Kandinsky. Madrid: Ediciones Siruela.

Henry, M. (2006). Fenomenologia não-intencional. Phénoménologie non intencionelle: une tàche por une phénoménologie à venir. Phainomenon (Centro de Filosofia da Universidade de Lisboa), Vol. 13, pp. 165-177. Disponível em: http://www.lusosofia.net/textos/michel_henry_fenomenologia_nao_intencional.pdf

Henry, M. (2003). Souffrance et Vie in Phénoménologie de la Vie, T I, Paris, PUF.

Henry, M.(2002). Prefácio. In: Martins, Florinda. (2002). Recuperar o Humanismo. Para uma fenomenologia da alteridade em Michel Henry. Cascais: Principia.

Jaspers, K. (1979). Psicopatologia geral. Psicologia Compreensiva, explicativa e fenomenologia. Rio de Janeiro: Atheneu. 2ª ed. (Originalmente publicado em 1911)

Kühn, R. (2010). Ipseidade e práxis subjectiva - Abordagens fenomenológicas e antropológicas segundo o pensamento de Michel Henry. Edições Colibri: Lisboa.

Husserl, E. (2006). Idéias para uma fenomenologia pura e para uma filosofia fenomenológica. Aparecida: Idéias e Letras.

Martins, F. (2010). Presença portuguesa na redefinição da fenomenologia e filosofia, hoje. In: Martins, F; Pereira, A. Michel Henry: o que pode um corpo? Lisboa; Universidade Católica Editora. p.70

Martins, F. (2009). Apresentação. In: Henry, M. Genealogia da psicanálise - o começo perdido. Curitiba: UFPR. pp.09-33. 
Martins, F. (2002). Recuperar o Humanismo. Para uma fenomenologia da alteridade em Michel Henry. Prefácio: Michel Henry. Cascais: Principia.

Meszaros, M. (2006). Filme: A Sétima Morada. DVD. Paulinas Multimídia. Produção: Itália, França, Hungria, Polônia.

Minkowska, F. (2007). Van Gogh, sa vie, sa maladie et son oeuvre. Paris: Hamattan. (Originalmente publicado em 1933).

Minkowska, F. (1978). Le Rorschach. A la recherche du monde des formes. France: Desclée de Brouwer. (Originalmente publicado em 1956).

Minkowska, F. (1949). De Van Gogh et Seurat aux dessins d'enfants. Paris: Presses du Temps Présent. In: Yazigi, L. (2002) Two styles of mental functioning and literary language: a phenomenological psychological reading of A. Machado and C. Cavafy. A tribute to Zena Helman. Psic.: Teor. e Pesq., Brasília, v. 18, n. 3.

Minkowski, E. (2000). La esquizofrenia. México: Fondo de Cultura Económica. (Originalmente publicado em 1927).

Minkowski, E. (1999). Traité de Psychopathologie. Paris: Collection Les Empêcheurs de penser en rond. (Originalmente publicado em 1966).

Minkowski, E. (1995). Le temps vécu. Paris: Press Universitaires de France. (Originalmente publicado em 1933).

Minkowski, E. (1970). Estudio psicologico y analisis fenomenologico de un caso de melancolia esquizofrenica. In: Minkoski, E; Von Gebsattel, V.E; Strauss, E.W. Antropologia de la alienación. Caracas, Venezuela: Monte Avila Editores. (Originalmente publicado em 1923).

Minkowski, E. (1965). Recueil d'articles 1923-1965. In: Eugène Minkowski et Zéna Helman (Orgs.). Cahiers du groupe Françoise Minkowska. $n^{\circ} 15$.

Minkowski, E. (1953). La shizophrénie. Psychopathologie des schizoïdes et des schizophrènes. 2ème éd. France: Desclée de Brouwer (Originalmente publicado em 1927).

Minkowski, E. (1952). Le Rorschach dans l'ouvre de françoise Minkowska. In : Eugène Minkowski et Zéna Helman (1965). Cahiers du groupe Françoise Minkowska, 115-117.

Monte, M; Antunes, A. (1984). De mais ninguém. Letra de música. CD Cor de rosa e carvão. Gravadora EMI.

Neruda, P. (1970). In Bijit, R.S.(2004). Habla Neruda - Memorias imposibles de corregir, Santiago: Editorial Catalonia. p.84.

Pereira, M. E. C. (2000). Minkowski ou a psicopatologia como psicologia do pathos humano. Rev. Latinoam. Psicop. Fund. III, 4, 143-155. 
Pessoa, F. 1888-1935. (1980) Fiç̧ões do interlúdio, 1: poemas completos de Alberto Caeiro. Rio de Janeiro: Nova Fronteira.

Picasso, P. (1937-1945). Anos de guerra [Exposição]. São Paulo: Museu de Arte de São Paulo Assis Chateaubriand; 21/09 a 15/11 - 1999.

Prinzhorn H (1995). Artistry of the Mentally ILL. In MacGregor JM (1922). Princeon University Press, pp.161-184.

Queluz, A. G. (1989). A vivência temporal na fala de crianças de pré-escola: uma abordagem fenomenológica. Tese de doutorado. São Paulo: Instituto de Psicologia, $268 \mathrm{p}$.

Rorschach, H. (1947). Psychodiagnostic. PUF: Paris (Trabalho originalmente publicado em 1921).

Safra, G. (2007). Profoco. Curso de Formação Continuada. Abril, 2007. Transferência: o estar diante, o estar em, o estar com. São Paulo: Edições Sobornost, DVD1, 2, 3, 4.

Safra, G. (2006). Hermenêutica na situação clínica. O desvelar da singularidade pelo idioma pessoal. São Paulo: Edições Sobornost.

Safra, G. (2005). Método de pesquisa: do projeto à elaboração do texto final. As metodologias contemporâneas e suas bases epistemológicas, como foco na pesquisa em Psicologia e Psicanálise. Aula ministrada no curso de pós-graduação em psicologia Clínica da USP em 16 de março de 2005. DVD Vídeo. Edições Sobornost.

Safra, G.(2004). A po-ética na clínica contemporânea. Aparecida: Edições Sobornost.

Safra, G.(1999). A face estética do Self. Teoria e Clínica. São Paulo: Unimarco Editora.

Safra, G.(1995). Momentos mutativos em psicanálise. São Paulo: Casa do Psicólogo.

Santoantonio, J \& Antúnez, A. E. A.(2010). Ateliê de desenho e Rorschach: estudo fenômeno-estrutural. Paideia. jan.-abr., Vol. 20, No. 45, 117-122.

Santoantonio, J., \& Antúnez, A. E. A. (2002). Atelier de pintura de livre expressão em hospital dia psiquiátrico [Versão Eletrônica]. Inter-Ação.com. Recuperado em 10 maio 2008, de http://www.ciec.org.br/Artigos/Revista_1/jacqueline.pdf

Silva Neto, N. A. (2004). A atualidade da Obra de Eugène Minkowski (1885-1972). BolAcad.Paul. Psicol. 24 (2): 50-62.

Stein, E. (2007). La estructura de la personalidad humana. 1.ed. Madrid: estúdios y ensayos. BAC. Filosofia y Ciências. 
Stein, E. (2005). Escritos filosóficos. Etapa fenomenológica. Obras Completas II. Madrid: Editorial Monte Carmelo.

Stein, E. (2002). Obras Completas. Vol. I. Escritos autobiográficos y cartas. Madrid: Editorial Monte Carmelo.

Stein, E. (2000). Philosophy of Psychology and humanities, Washington, D.D., ICS Publications. (In: Safra, G. 2006)

Ternoy, M. (1999). Rorschach, psicosis y alucinaciones: enfoque fenomeno-estructural. Psicodiagnosticar , v. IX, Año XI, 34-46.

Ternoy, M. (1997). Uma característica específica da visão em imagens no alucinado: o detalhismo. Livro I Congrès de la Société Internationale de Psychopathologie Phénoméno-structurale. I Congresso da Sociedade Brasileira de Rorschach e Outros Métodos Projetivos. Ribeirão Preto: ASBRo, p.192-205.

Ternoy, M. (1987). L'espace pictural de groupe. Rorschach et psychopathologie phénoméno-structurale. Expression et psychopathologie. In Colloque Octobre. France: Recueil no. 3; pp.12-20.

Van Gogh, V. (2010). Cartas a Théo. Tradução de Pierre Ruprecht. Porto Alegre : L\&PM Pocket. $416 \mathrm{p}$.

Villemor Amaral, A.E.; Yazigi, L.(Orgs.) (2010). Psicopatologia fenômeno-estrutural. São Paulo: Casa do Psicólogo.

Wondracek, K. H. K. (2010a). Ser nascido na Vida: a fenomenologia da Vida de Michel Henry e sua contribuição para a clínica. Tese de doutorado. São Leopoldo: Escola Superior de Teologia. Disponível em: http://tede.est.edu.br/tede/tde_busca/arquivo.php?codArquivo=245 